\title{
ELECTROCHEMISTRY OF Thiobacillus ferrooxidans REACTIONS WITH PYRITE
}

DOE PROJECT No.: DE-FG22-88PC88920

DOE /PC/88920--T31

DE93 011540

FINAL REPORT

DATE: January 20, 1993

PREPARED FOR:

\author{
U.S. DEPARTMENT OF ENERGY \\ PITTSBURGH ENERGY TECHNOLOGY CENTER \\ PITTSBURGH, PA 15236-0940
}

PREPARED BY:

Professor BATRIC PESIC, Principal Investigator

UNIVERSITY OF IDAHO

DEPARTMENT OF METALLURGY

MOSCOW, IDAHO 83843

Professor DAVID J. OLIVER, Co-Principal Investigator

INBEUM KIM, Graduate Student

GOPAL C. DE, Graduate Student 


\section{TABLE OF CONTENT}

List of Figures

List of Tables

ix

Abstract

$\mathrm{x}$

Chapter I

Electrochemistry of $T$. ferrooxidans interactions with pyrite

Introduction

Materials and Methods 2

Electrochemical setup 2

Pyrite Electrode 3

Solutions and Bacteria 3

Cyclic Voltammetry 5

SEM and EDX Study 5

CHNOS Analysis 6

Atomic Absorption Analysis 7

$\begin{array}{ll}\text { Results and Discussion } & 7\end{array}$

Abiotic Systems $\quad 7$

Biotic Systems 9

Surface Reaction Product Characterization $\quad 12$

SEM $\quad 12$

Chemical Analysis 15

Mechanism of Jarosite Formation 17

Chapter II

Effect of Heavy Metals on the Iron Oxidazing Ability of T. ferrooxidans

Introduction

Materials and Methods

Materials and Equipment

Procedure

Experiments Without Heavy Metals 37

Experiments With Heavy Metals 37

Standard Experimental Conditions 38

Results and Discussion

Results of Experiments without Heavy Metals 38

Effect of pH 38

Effect of Cell Concentration $\quad 39$

Effect of $\mathrm{Fe}$ (II) Concentration 40

Effect of Temperature 43 
Results of Experiments With Heavy Metal Ions

Effect of Common Heavy Metal Ions

Effect of Silver Ion Concentration

Effect of $\mathrm{Fe}$ (II) Concentration in the Presence of Silver

Effect of Temperature in the Presence of Silver

Oxidation of $\mathrm{Fe}$ (II) with Bacteria Conditioned with Silver

Effect of Time

Effect of $\mathrm{pH}$

51

52

Mechanism of Inhibition of Silver Ions

53

Mechanism of Inhibition of $\mathrm{Fe}$ (II) Oxidation

by $\mathrm{T}$. ferrooxidans in the Presence of $\mathrm{Hg}$ (II)

Chapter III

Redox Potential Techniques to study Factors

of Importance during Reactions of $\mathrm{T}$. ferrooxidans

Introduction

Experimental Details

Culture Preparation

Fermentation/Growth and Harvesting

87

Electrochemical Cell

88

Experimental Procedure

Stardard Experimental Conditions

89

90

91

Results

92

Part I: Effect of Various Parameters on Growth

of $T$. Ferrrooxidans

92

Effect of $\mathrm{pH}$

Effect of Time on the Growth of

T. ferrooxidans

95

Effect of Environmental Conditions

Part II: Effect of Ferrous sulfate Concentration

and $\mathrm{pH}$ on Activity of Harvested Cells

Effect of Ferrous Sulfate Substrate Concentration

Effect of $\mathrm{pH}$

Conclusions

References 


\section{LIST OF FIGURES}

Fig. 1 Schematic electrochemical measurement system

1. Water bath: Flow controller (FC), Heater and agitator

$(H \& A) ; \quad 2$. Electrochemical cell; 3. Platinum counter electrode (CE); 3. Pyrite electrode assembly (WE); 5. SCE reference electrode.

Fig. 2 Disassembled and assembled pyrite working electrode.

Fig. 3a-c Cyclic voltammograms of pyrite in the abiotic system: a) water at $\mathrm{pH}=2$, b) water at $\mathrm{pH}=2$ to which medium salts were added, c) in the presence of medium + ferrous sulfate.

Fig. 4a-c Cyclic voltammograms of pyrite as a function of time in the biotic system: a) at the beginning, 0-day, b) after 1-day, c) after 2-day bioleaching.

Fig. 5a-c Cyclic voltammograms of pyrite as a function of time in the biotic system: a) after 3-day, b) after 4-day, c) after 5day bioleaching.

Fig. 6 Cyclic voltammetry of pyrite after 25 days of exposure to abiotic ferric sulfate solution. 
Fig. 7a-f SEM photomicrographs of pyrite surface during bioleaching with $\mathrm{T}$. ferrooxidans in the growth stage: a) 2 hrs; b) 1-day; c) 1.5-day; d) 2-day; e) 2.5-day and f) 5-day. The arrows in (b) and (c) identify some of the cells and the locations where jarosite product formation initiates.

Fig. 8a-b SEM of pyrite surface after 5 days of bioleaching with I. Eerrooxidans.

a) Low magnification: 50x. The product layer is brittle when dry and readily peels off.

b) A particular segment of the product layer seen in (a), but magnified 1,000x. A noticeable feature is the continuous layer on the pyrite surface, somewhat separated from the surface, perhaps because of drying. On top of the continuous blanket is a massive deposition of globular reaction products. Careful inspection can also identify many "intact" bacteria cells in the continuous layer.

Fig. 9 X-ray diffractograms obtained with:

a) reaction product formed during abiotic oxidation of ferric with air (25 days),

b) reaction product after 5 days of bioleaching at $\mathrm{pH}=2$,

c) reaction product after 5 days of bioleaching at $\mathrm{pH}=2.5$,

e) synthetic jarosite (ASTM 22-827). 
Fig. 10 Schematic representation of jarosite nucleation on the cells, jarcsite growth, and final cell collapse observed during bioleaching with $\underline{T}$ ferrooxidans in the growth stage. The early nucleation sites can be recognized on some of the cells in Fig. 7b (1-day) and Fig. 7c (1.5-days). Near cell collapse can be seen in Fig. 11 below.

Fig. II SEM photomicrographs of $\mathrm{T}$. ferrooxidans cells from two different pyrite areas at much higher magnification, 15,000x. Inspection of individual cells reveals distinct lines along which the cells will collapse into an agglomerate of small globular products. The left photo also demonstrates the agglomeration of many individual bacterial cells, the final fate of which will be the transformation into a large globe.

Fig. 12 Effect of $\mathrm{pH}$ on the redox potential of pyrite electrode during bacterial oxidation of $\mathrm{Fe}$ (II).

Fig. 13 Rate constant of microbial oxidation of Fe(II) as a function of cell density in terms of $\mathrm{OD}_{590}$.

Fig. 14 Rate constant of microbial oxidation of Fe(II) as a function of $\mathrm{Fe}$ (II) concentration, at $\mathrm{pH}$ 1.7. (Circles $\mathrm{OD}_{590}$ 5.85; Squares: $\mathrm{OD}_{590} 2.8$; Triangles: $\mathrm{OD}_{590}$ 1.41). Closed symbols were experiments without silver; Open symbols were experiments with 10 $\mathrm{mg} / \mathrm{L}$ silver. 
Fig. 15 Initial rate of microbial oxidation of $F e$ (II) as a function of initial concentration of Fe(II) in the absence of heavy metal ions. Three different cell densities were used.

Fig. 16 Rate constants of the microbial oxidation of Fe(II) as a function of $\mathrm{Fe}$ (II) concentration at $\mathrm{pH}$ 1.7. Rate constants evaluated up to $15 \mathrm{~min}$ (open symbols) and $60 \mathrm{~min}$ (closed symbols) of reaction time. (Squares $\mathrm{OD}_{590} 2.8$; triangles $\mathrm{OD}_{590} 1.41$ ).

Fig. 17a Effect of initial Fe(III) concentration on the rate of microbial oxidation of $\mathrm{Fe}(\mathrm{II})$.

Fig. 17b Dixon's method of analysis of competitive inhibition of $\mathrm{Fe}(I I I)$.

Fig. 18 Initial rate of microbial oxidation of $F e(I I)$ as a function of initial Fe(II) concentration in the absence and in the presence of silver. (Squares: No silver present; Triangles: $10 \mathrm{mg} / \mathrm{L}$. Open symbols: 4-day old bacterial batch; Closed symbols: 5-day old bacterial batch).

Fig. I9 Lineweaver-Burk plot for the microbial oxidation of $\mathrm{Fe}(\mathrm{II})$ in the absence (squares) and in the presence of $10 \mathrm{mg} / \mathrm{L}$ silver (triangles). (Open symbols: 4-day old bacterial batch; closed symbols: 5-day old batch). 
Fig. 20 Arrhenius plot for the bacterial oxidation of Fe(II) in the absence and in the presence of silver (10 $\mathrm{mg} / \mathrm{L})$.

Fig. 21 Effect of silver concentration on the redox potential of solution during microbial oxidation of Fe(II). There was no conditioning of bacteria with silver.

Fig. 22 Effect of silver concentration on the rate of microbial oxidation of $\mathrm{Fe}$ (II) at three different initial $\mathrm{pH}$ values. There was no conditioning of bacteria with silver.

Fig. 23 Effect of time on the redox potential of pyrite electrode during microbial oxidation of Fe(II). Bacteria was conditioned with solutions containing silver (10 mg/L).

Fig. 24 Rate constant of microbial oxidation of $F e(I I)$ as a function of conditioning time of bacteria with silver containing solutions.

Fig. 25 Effect of $\mathrm{pH}$ on the rate constant of microbial oxidation of $\mathrm{Fe}$ (II) as a function of silver presence and conditioning time.

Fig. 26a SEM photomicrograph of $\underline{T}$. ferrooxidans taken from an experiment of microbial oxidation of Fe(II) in the presence of $2.5 \mathrm{mg} / \mathrm{L}$ silver. 
Fig. 26b SEM photomicrograph of $T$. ferrooxidans taken from a control experiment (no silver) of microbial oxidation of Fe(II).

Fig. 27a TEM photomicrograph of $T$. ferrooxidans taken from a control experiment (no silver) of microbial oxidation of Fe(II).

Fig. 27b TEM photomicrograph of $T$. ferrooxidans taken from an experiment of microbial oxidation of $\mathrm{Fe}$ (II) in the presence of $2.5 \mathrm{mg} / \mathrm{L}$ silver.

Fig. 27C Higher magnification of TEM photomicrograph of $T$. ferrooxidans taken from an experiment of microbial oxidation of $\mathrm{Fe}$ (II) in the presence of $2.5 \mathrm{mg} / \mathrm{L}$ silver.

Fig. 28a X-ray emission of spectrum (EDX) of the lighter area of the bacteria cell in Fig. 27a.

Fig. 28b X-ray emission of spectrum (EDX) of a dark spot of the bacteria cell in Fig. $27 \mathrm{~b}$.

Fig. 29 Lineweaver-Burk plot for microbial oxidation of $\mathrm{Fe}$ (II) in the absence (squares) and in the presence of $10 \mathrm{mg} / \mathrm{L}$ mercury (triangles). (Closed symbols: data from redox potential measurements; Open symbols: data from optical density measurements). 
Fig. 30 Arrhenius plot for the bacterial oxidation of $F e(I I)$ in the absence and in the presence of mercury (10 mg/L).

Fig. 31 Redox potential variation during fermentation of $\underline{T}$. ferrooxidans at different initial solution $\mathrm{pH}$.

Fig. 32 Effect of fermentation $\mathrm{pH}$ on activity of harvested $\mathrm{T}$. ferrooxidans. Activity measured in the electrochemical cell.

Fig. 33 Effect of time on growth of $\mathrm{T}$. ferrooxidans. Activity of harvested cells measured in the electrochemical cell.

Fig. 34 Effect of recycling of harvested bacteria into the fresh medium solution. Between recycling, the activity of harvested bacteria measured in the electrochemical cell.

Fig. 35 Effect of ferrous sulfate addition on growth of $T$. ferrooxidans during fermentation. Activity of harvested bacteria measured in the electrochemical cell.

Fig. 36 Effect of ferrous concentration on the oxidation of ferrous irun with T. ferrooxidans. The curves are raw data of redox potentials acquired with time during oxidation of ferrous iron with harvested cells.

Fig. 37 Rate of ferrous iron oxidation with harvested $\underline{T}$. 
ferrooxidans cells as a function of substrate concentration.

Fig. 38 Lineweaver-Burk plot: Effect of substrate concentration. Data from Fig. 37.

Fig. 39 Effect of $\mathrm{pH}$ on the rate of $\mathrm{Fe}^{2+}$ oxidation with harvested T. ferrooxidans cells. 


\section{LIST OF TABLES}

Table 1 The Compositions and Concentrations of Inorganic Salts Used for Preparation of Medium Solutions ( $g / 1$ )

Table 2 Chemical Analysis of Reaction Product. Analysis performed by CHNOS, EDX, and Atomic Absorption (AA).

Table 3 Efiect of $\mathrm{pH}$ on the observed rate constant of the microbial oxidation of ferrous iron.

Table 4 Effect of temperature on the rate constant of the bacterial oxidation of ferrous iron.

Table 5 Effect of heavy metal ions on the rate of Fe(II) oxidation by T. ferrooxidans.

Table 6 Results of AA analysis of samples taken from experiments to diagnose the fate of silver.

Table 7 The Composition of Medium Solution $(\mathrm{g} / 1)$.

Table 8 standard conditions during fermentation and activity measurement . 
ELECTROCHEMISTRY OF Thiobacillus ferrooxidans INTERACTIONS WITE PYRITE

\section{ABSTRACT}

A cyclic voltammetry technique was used to study the interactions of pyrite, during bioleaching, with the bacterium Thiobacillus ferrooxidans over its entire growth cycle. Invariably, the fyrite surface drastically changed its properties on the second day of growth (bioleaching). After two days, the cyclic voltammograms (CVs) were insensitive to convective diffusion produced by stirring. The product layer was examined by scanning electron microscopy (SEM), X-ray diffraction, and chemical analysis. The SEM study revealed an extremely high density of bacteria on the pyrite surface. The high density of bacteria, along with the solid reaction products formed on the pyrite surface, created conditions for crack/pore diffusion, explaining why the CVs became insensitive to convective diffusion (stirring) in solution. $\mathrm{x}$-ray diffraction study confirmed jarosite as a product layer. A $m$ ahanism is proposed by which Thiobacillus ferrooxidans cells serve as nucleation sites for jarosite formation. Other electrochemical techniques were also examined, but they were not as informative as the cyclic voltammetry techniques and the refore are not reported here. Both mineral and coal pyrite were used for the studies. It was found that phenomena described in this work were the same for both kinds of pyrite, and distinction between these two should not be made. 
The effect of some typical heavy metal ions on the iron oxidizing ability of Thiobacillus ferrooxidans was studied using electrochemical and other physicochemical techniques. Electrochemizal investigation was conducted using a method based on change in redox potential. Experiments were performeä by adding an aliquot of a separately prepared bacterial concentrate into the solution of ferrous ion and monitoring the redox potential for 1590 minutes. Pyrite was used as the indicator electrode. Parameters examined were $\mathrm{pH}$; microbial cell density; ferrous, ferric, and heavy metal concentration; temperature; and preconditioning period of the bacteria with heavy metal and other ions.

Our results demonstrate that the rate of ferrous ion oxidation is influenced by $\mathrm{pH}$ (optimum $\mathrm{pH}$ range is 1.7-2.0), microbial cell concentration, and $\mathrm{Fe}$ (II) concentration. The mechanism of the bacterially mediated oxidation of ferrous iron is found to be remarkably sensitive to temperature changes. In the vicinity of the optimum temperature $\left(25^{\circ} \mathrm{C}\right)$, the reaction is likely to be controlled by the diffusion of $\mathrm{Fe}$ (II) ions through the cell wall of the bacteria, whereas below the temperature range $18-25^{\circ} \mathrm{C}$, reaction kinetics may be the rate-controlling factor. In addition, we observed that the presence of some cations, e.g., Ag(I), Hg(II), $\mathrm{Pb}(\mathrm{II})$, and $\mathrm{Cd}(\mathrm{II})$, at a concentration of $10 \mathrm{mg} / \mathrm{L}$, inhibits the microbial oxidation of $\mathrm{Fe}(\mathrm{II})$. While the presence of $10 \mathrm{mg} / \mathrm{L}$ of As(III), $M n(I I)$, and $S n(I I)$ may not be conducive to the biooxidation of $\mathrm{Fe}$ (II), the presence of $10 \mathrm{mg} / \mathrm{L}$ of $\mathrm{Co}$ (II), Cu(II), 
and $\mathrm{Zn}$ (II), and anions like $\mathrm{Cl}^{-}$and $\mathrm{NO}_{3}{ }^{-}$, does not have an observable effect on the Fe(II) oxidizing activity of the bacteria. In the presence of $10 \mathrm{mg} / \mathrm{L}$ silver, the reaction may be kinetically controlled over the temperature range $5.5-25^{\circ} \mathrm{C}$. Inhibition of microbial Fe(II) oxidation in the presence of silver may take place via a mixed mechanism in which silver may bind with both the enzyme and the enzyme-Fe(II) complex. By contrast, Hg(II) may inhibit the microbial oxidation of Fe(II) by an uncompetitive mechanism, according to which it may bind with the enzyme-Fe(II) complex. In the presence of $10 \mathrm{mg} / \mathrm{L} \mathrm{Hg}$ (II), bacterial oxidation of Fe(II) is likely to be controlled by the diffusion of ferrous ions through the cell wall of $\mathrm{T}$. ferrooxidans.

The redox putential measurement method was used to study the effect of various parameters on the growth of inoculated and the activity of harvested I. ferrooxidans. The parameters studied were solution $\mathrm{pH}$, substrate concentration, and time. During growth, increasing the $\mathrm{pH}$ up to $\mathrm{pH} 1.5$ increased the rate of growth. From $\mathrm{pH} 1.5$ to $3.5, \mathrm{pH}$ was not an important factor. Above $\mathrm{pH} 3.5$, the growth rate rapidly declined, and I. ferrooxidans did not grow at pH above 4.0. Growth of bacteria was enhanced more by repeated transfer of cells into fresh media than by the addition of equivalent amounts of ferrous sulfate during growth in the same medium.

The redox potential. method of measuring the activity of bacteria can also be used to calculate the kinetic parameters in 
xiii

the Michaelis-Menten enzyme kinetic models. This was demonstrated by studying the effect of ferrous sulfate concentration on the rate of iron oxidation with harvested cells, and by using the Lineweaver-Burk method to obtain the $K_{M}$ and $V_{\max }$ values. The effect of $\mathrm{pH}$ on the activity of harvested cells was also examined. 


\section{CHAPTER I}

\section{ELECTROCHEMISTRY OF BIOLEACHING OF PYRITE WITH T. ferrooxidans}

\section{INTRODUCTION}

Understanding the interactions of $\mathrm{T}$. ferrooxidans with pyrite is important from both metallurgical and environmental points of view. In metallurgical applications, $\underline{T}$. ferrooxidans can oxidize pyrite to liberate encapsulated gold (1), or produce ferric ion and acid for copper leaching in dumps/heaps (2). From environmental. point of view, this bacterium can clean pyrite from coal (3), but may be detrimental because of its role iil the oxidation of sulfide minerals and release of heavy metals and acids into mine waters (4). In either case, successful control depends on understanding interactions of $\mathrm{T}$. Eerrooxidans with pyrite.

Although important, the pertinent reaction mechanisms have received only limited study. Most studies have focused on the suitability of ores, coals, and cultures for bioleaching. Mechanistic studies have been performed by Iwasaki and Natarajan (5), Natarajan and Iwasaki (6), Mehta and Murr (7,8), and Berry, Murr and Hiskey (9), who all used corrosion principles to explain the reactions involved. Most recently, Chia et al. (10) studied the electrochemical aspects of pyrite oxidation by $\mathrm{T}$. ferrooxidans during the leaching of a Canadian uranium ore. He found that pyrite oxidation was controlled by soild-state diffusion phenomena. Palencia et al. (11) suggested that $\mathrm{T}$. ferrooxidans modulated the 
solution chemistry (the ferric ion activity) and had a limited effect on the electrochemical reactions on the pyrite surface.

This work examines the interfacial phenomena of $T$. ferrooxidans on pyrite by using the cyclic voltammetric technique. Cyclic voltammetry was selected because it is the most versatile electrochemical technique available for the mechanistic study of redox systems (12-14). The cyclic voltammetry results were correlated with the surface reaction products, which were characterized by using SEM, X-ray diffraction, and chemical analysis techniques.

\section{MATERIALS AND METHODS}

Electrochemical setup

Electrochemical measurements were performed with a potentiostat/ galvanostat (EG\&G PARC, Model 273) controlled by an external computer (EG\&G PARC, Model 270 software) (Figure 1). EG\&G PARC uses the American convention for currents (anodic currents are negative).

The electrochemical cell was actually a 2 -liter glass kettle, which was also used as a bioreactor for growth of bacteria. One of the kettle's cover ports was used to supply air, and the other three were used to accommodate a working electrode (pyrite), a standard reference electrode (calomel) with a salt bridge, and a Pt counter-electrode, respectively. The kettle was placed into a water bath to maintain a temperature of $25^{\circ} \mathrm{C}$. 


\section{Pyrite Electrode}

Pyrite electrodes (about $0.5 \times 2 \times 2 \mathrm{~cm}$ ) were prepared Erom a mineral-pyrite specimen (Ward's Geological Services). The pyrite was placed in a specially built holder with a copper wire for electrical contact on one side, and a high-density polyethylene plastic cover and an o-ring (diameter $=1 \mathrm{~cm}$ ) on the other side. This design allowed for quick disassembly (Figure 2a), pyrite polishing, and assembly (Figure 2b). When the holder was submerged, only pyrite was in contact with the solution, its surface area determined by the diameter of the o-ring. The resistivicy batween the face of the pyrite and the other end of the copper wire was within 5 ohms.

\section{Solutions and Bacteria}

All solutions and glassware were autoclaved $\left(30 \mathrm{~min}, \mathrm{~T}=120^{\circ} \mathrm{C}\right.$, $\mathrm{p}=1.5 \mathrm{~atm}$ ) before use. Analytical grade salts were used to prepare the nutrient medium (Table 1 ).

Table 1. The Compositions and Concentrations of Inorganic Salts Used for Preparation of Medium Solutions $(\mathrm{g} / \mathrm{l})$

$\begin{array}{llll}\left(\mathrm{NH}_{4}\right)_{2} \mathrm{SO}_{4} & 0.15 & \mathrm{~K}_{2} \mathrm{HPO}_{4} & 0.15 \\ \mathrm{KCl} & 0.15 & \mathrm{MgSO}_{4} \cdot 7 \mathrm{H}_{2} \mathrm{O} & 3.36 \\ \mathrm{CaCl}_{2} & 0.97 & \mathrm{Al}_{2}\left(\mathrm{SO}_{4}\right)_{3} \cdot 18 \mathrm{H}_{2} \mathrm{O} & 2.25 \\ \mathrm{MnSO}_{4} & 0.12 & \left(\mathrm{NH}_{4}\right)_{6} \mathrm{MO}_{7} \mathrm{O}_{24} \cdot 4 \mathrm{H}_{2} \mathrm{O} & 25 \mu 1 \\ & & (\mathrm{ErOm} 1 \mathrm{gram} / 1 \text { iter stock solution) }\end{array}$

Inoculant: Inoculant served for the long term maintainance of the 
bacterial stock solution, and for the inoculation in the experimental studies. The strain of $\mathrm{T}$. ferrooxidans (ATCC 13598) was maintained by transferring $10 \mathrm{ml}$ of bacterial stock solution (7-day old) into $500 \mathrm{ml}$ Erlenmeyer flask containing $250 \mathrm{ml}$ of fresh medium salt (Table 1) at $\mathrm{pH} 2$ to which $5 \mathrm{ml}$ of stock ferrous sulfate solution was also added. The Erlenmeyer flasks were placed in an incubator (Lab Line shaker, at $25^{\circ} \mathrm{C}$ and at $180 \mathrm{rpm}$ stirring speed). Stock ferrous sulfate solution was prepared by dissolving $37.5 \mathrm{~g}$ of $\mathrm{FeSO}_{4} \cdot 7 \mathrm{H}_{2} \mathrm{O}$ in $100 \mathrm{ml}$ of water at $\mathrm{pH} 2$. It was further sterilized and filtered through a sterile 0.45 micron filter (Nalge).

As an inoculant for the experimental studies, a flask was taken from the incubator and its entire content $(255 \mathrm{ml})$ of bacterial stock solution (always five days old) was transferred into the bioreactor containing two liters of medium salts solution (Table 1). Sterilized $\mathrm{FeSO}_{4} \cdot 7 \mathrm{H}_{2} \mathrm{O}, 45$ grams, was subsequently added as the energy source, and the bacterial growth initiated. At the end of an experiment, the cells were harvested and their activity and yield determined. The activity was determined by using the method developed by Pesic et al. (15). The yield was deterimined after harvesting (Millipore Minitan system, $0.1 \mu$ ) by using the optical density method. In all experiments, the activity (first order reaction rate constant) of harvested cells was about 0.06 1/sec. The final amount of cells was about $20.4 \mathrm{mg}$ total dry weight, or $2.62 \times 10^{11}$ cells, and it was exceptionally reproducible throughout the entire study period ( $3-4$ years). 


\section{Cyclic Voltammetry}

Abiotic Systems: In the abiotic phase of this study, cyclic voltammograms of pyrite were recorded in each of the following solutions: pure water, water + sulfuric acid, medium salts, and medium salts + ferrous sulfate.

Biotic Systems: In the biotic phase, stock culture (255 ml) was added to the medium salts + ferrous sulfate solution to initiate bacterial growth. In this phase, cyclic voltammetry experiments were performed daily, under both stationary conditions and stirred conditions achieved by air bubbling. During growth, the cyclic voltammetric experiments were done with two indicator pyrite electrodes, one of which was continuously kept in the solution. Because the surface of this pyrite electrode was expected to undergo continuous changes from bacterial action, it was called the "conditioned" electrode. This approach differed from that used with the abiotic systems, where the pyrite electrode was polished before each experiment. The second, or "control" pyrite electrode was used daily and was polished before each experiment.

\section{SEM and EDX Study}

The pyrite samples for SEM (AmRay, Model 1830) examination were prepared by crushing solid pyrite mineral into grains $4-5 \mathrm{~mm}$ in size. Each of the thirteen selected grains was then carefully polished on one side, rinsed with deionized water, and mounted on a specially built sample holder, which was then placed into freshly 
prepared bacterial growth solution of the same composition as was used in the CV studies. After inoculation of solution, a pyrite sample was withdrawn at 2,6 , and $12 \mathrm{hrs}$, and $1.0,1.5,2.0,2.5$, $3.0,3.5,4.0,4.5,5.0$, and 5.5 days. After the sample was withdrawn, it was gently rinsed several times with acidified water $(\mathrm{pH} 2)$ and immediately transferred into a vial with glutaraldehyde solution to fix and preserve the oriyinal shape of any cells that might have adhered to the surface. These pyrite samples were used only for the SEM study and were never subjected to electrochemical or other studies. Pertinent areas (globular products and continuous phases, for example), identified by SEM, were simultaneously analyzed by energy dispersive $x$-ray spectrometry, EDX (Kevex asseccory).

\section{CHNOS Analysis}

Carbon, hydrogen and nitrogen were determined by Perkin Elmer, Model 240 D, CHN Analyzer. Oxygen and sulfur were determined by Perkin Elmer, Series 240, Analyzers. To prepare the samples for analysis of the reaction products, the pyrite specimens $10.5 \times 2 \times$ $2 \mathrm{~cm}$ ) were mounted onto the same electrode holders as shown in Figure 2. Pyrite surface area exposed to bacterial solution was $0.73 \mathrm{~cm}^{2}$. Pyrite specimens were withdrawn from the solution after two and five days of bacterial growth, submerged several times in the acidified water solution to remove the loose product particles, and dried. After drying, pyrite specimens were removed from the holder, and the reaction product carefully scraped off with a 
surgical blade. About $0.1 \mathrm{mg}$ and $3.4 \mathrm{mg}$ of reaction product was recovered from pyrite specimens (no underlying pyrite was scraped off) after two and five days of growth, respectively.

Atomic Absorption Analysis (AA)

The abiotic and biotic reaction products (present in the leach solution; not on pyrite surface) were recovered by filtration, washed with acidified water ( $\mathrm{pH} 2)$, and dried. An aliquot sample was digested in aqua regia and the solution analyzed for iron by atomic absorption (Varian, Model spectra 10/20).

\section{RESULTS AND DISCUSSION}

\section{Abiotic Systems}

The CV of pure water at $\mathrm{pH} 2.0$ is given in Figure 3 a for both stationary and stirred by air bubbling conditions. Under stationary conditions, in addition to the anodic currents produced by the oxidation of water, some electrochemical activity occurred in the region between 0.3 and $0.5 \mathrm{~V}$, as indicated by the presence of slight reduction peaks. This is the same potential region where iron redox reactions take place. The soluble iron species, $\mathrm{Fe}^{3+}$, was produced during scanning in the anodic direction, at higher potentials $(0.5-0.8 \mathrm{~V})$. The reduction currents were absent under the stirred conditions because the generated ferric ion species produced in the anodic scan were removed by convection from the pyrite surface before the reduction potential region was reached. 
The CVs of the medium salts solution ( $\mathrm{pH} 2.0$ ) are given in Figure 3b. Although medium salts contain many cations and anions $\left(\mathrm{K}^{+}, \mathrm{Mg}^{2+}, \mathrm{Ca}^{2+}, \mathrm{Al}^{3+}, \mathrm{Mn}^{2+}, \mathrm{NH}_{4}, \mathrm{Cl}^{-}, \mathrm{SO}_{4}^{-}, \mathrm{HPO}_{4}^{-}\right)$, none of these species was electroactive on the pyrite surface in the entire voltage range scanned, as shown by the absence of any additional currents. The cyclic voltammetric study of bacterial action was therefore simplified because in the following stages only the oxidation-reduction peaks produced by iron species needed to be examined.

The CV of medium salts with ferrous sulfate is given in Figure 3c. Under stationary conditions well-resolved peaks, characteristic for the oxidation-reduction of iron species, were obtained. In the anodic direction (left to right), the oxidation of ferrous ion began at about $0.4 \mathrm{~V}$ and peaked at about $0.55 \mathrm{~V}$. In the reverse direction, the ferric ions that accumulated on the pyrite surface during the anodic scan became reduced back to ferrous ion, and peak currents were produced at about $0.34 \mathrm{~V}$. Because the separation of peak currents was more than $59 \mathrm{mV}$, about $200 \mathrm{mV}$, the oxidation-reduction reactions of iron species on the pyrite surface were irreversible, and were consequently controlled by charge transfer (16). Under stirred conditions, the oxidationreduction currents of iron species were not present because the electroactive species were removed by convective diffusion (air bubbling) faster than they were generated by the imposed potentials. 


\section{Biotic systems}

The biotic stage of the study was initiated by the addition of $255 \mathrm{ml}$ of $\mathrm{T}$. ferrooxidans inoculant to the medium solution. The interaction of the bacteria with pyrite was monitored daily by performing cyclic voltammetric studies as described above. The control electrode was used to compare the CVs of the conditioned pyrite electrode with the CVs of the fresh pyrite surface during bioleaching. During bioleaching in the growth stage, air was continuously bubbled through the solution, and it was briefly discontinued only when the CVs under stationary conditions were recorded. Only the results with the conditioned electrode are presented here; the results with the control electrode were presented elsewhere (17).

Figure 4 a shows that immediately after bacteria were added, the CVs did not differ from the last abiotic cyclic voltammograms (Figure 3c) because of the low initial concentration of bacteria in the reactor. Also, because the cyclic voltammetry experiments were performed immediately after bacteria were added, bacteria were not yet attached to the surface of the pyrite electrode or caused any noticeable changes in surface properties.

Day-0 began when the bacteria were added. After one day (Figure $4 \mathrm{~b}$ ) the CVs recorded for the conditioned electrode were not much different from those obtained at day-0. The most important change on the pyrite surface occurred after two days of bioleaching (Figure 4C), as shown by several remarkable differences between second-day CVs and those recorded previously. Under stationary 
conditions, the characteristic iron oxidation-reduction peaks were almost completely eliminated. The currents produced were reduced so much that the plotting scale had to be significantly expanded in order to see some currents in the characteristic iron redox region of 0.3 to $0.5 \mathrm{~V}$. Furthermore, the differences between the CVs obtained during stationary and stirred conditions were absent, i.e. the convective diffusion effect during stirring was absent. The cyclic voltammetry of the fresh pyrite surface (control electrode) resolved the characteristic iron redox peaks, which were not quite identical to the CVs at the preceding stages of bioleaching, but were similar enough to indicate that changes produced on the conditioned electrode were not due, entirely, to changes in the aqueous phase. Instead, the characteristic redox peaks of the conditioned pyrite electrode were eliminated by drastic changes in the surface properties of the pyrite, most probably caused by an adhering layer of bacteria or by a product of bacterial oxidation. The absence of CV currents suggested that the pyrite surface became isolated from the solution.

After three days of bioleaching in the growth stage, the peaks characteristic for iron oxidation and reduction clearly emerged again for the conditioned electrode (Figures 5a). The resolved anodic and cathodic current peaks were closer at this time than they were at day-o, indicating that the system was approaching reversible conditions. However, the oxidation-reduction reactions were much less extensive than at day-0, as evidenced by the much lower corresponding currents. Another important difference is that 
the CVs obtained urdex stirred conditions are identical to those obtained under stationary corditions, i.e., the CVs were insensitive to the effects of convective diffusion.

similar results from cyclic voltammetry were obtained after four (Figure 5b) ar five days (Figure 5c) of bioleaching in the growth stage, when slightly higher peaks were obtained. The separation of current peaks was about $80 \mathrm{mV}$, which is not too far from the $59 \mathrm{mV}$ required by the definition for reversible systems.

The insensitivity of the conditioned pyrite electrode to the effects of convective diffusion (turbulence) beyond two days of exposure to the biotic solution could be due to: (1) An adhering layer of bacteria comletely covering the pyrite surface and controlling the electrochemical reactions by the mechanism of charge transfer; (2) independence of reaction rates from the effects of stirring was caused by the mass transfer of electroactive species through the layer of bacteria (not through the bacterial cells themselves, but between the cells in a layer); (3) Eormation of a porous product layer by bacterial action controlling the mass transfer of iron species. The last two conditions, would create the conaitions for pore diffusion, under which the influence of external forces, such as the convection produced by stirring, would not be seen.

To test the first hypothesis, the metabolic role of adhering bacteria, the conditioned pyrite electrode was withdrawn from the solution after five days of bioleaching, sterilized with ethyl alcohol, and dried. Under these conditions, the electrode that was 
previously biotic because of the adhering bacteria was converted into an abiotic electrode. When the cyclic voltammetric study was repeated with this treated electrode, either in the original bioleaching solution or in a bioleaching solution containing fresh ferrous sulfate, identical results were obtained (Figure 5c), which eliminated any metabolic role for bacteria adhering to the electrode.

To test the role of diffusion through a product layer, a separate experiment was performed. Its objective was to form a reaction product layer on the electrode by leaching under abiotic conditions, and then to perform cyclic voltammetry under stationary and stirred conditions with the modified electrode. The polished pyrite electrode was submerged in an abiotic ferric sulfate solution. After 25 days of leaching, a sufficient product layer was formed on the pyrite surface to produce exactly the same effect as discussed above, the insensitivity of the CV to the effects of stirring (Figure 6). It appeared that pore diffusion phenomena were important, but exactly which pores--those in the layer of bacteria or those in the solid abiotic reaction product layer--was still unknown. It was therefore decided to characterize the reaction product by following the same experimental protocol as in the cyclic voltammetric study.

\section{Surface Reaction Product Characterization}

Scanning Electron Microscopic Examination

As described above, the cyclic voltammetric studies during 
bacterial growth stage of leaching were performed as a function of time. To correlate the observed results with the physicochemical changes on the pyrite surface, separate pyrite samples for SEM examination during growth were prepared under the exact same conditions and within the same time intervals.

Even after only two hours of bioleaching, bacterial cells could be located on the pyrite surface (Figure 7a). After 1-day of growth, a photomicrograph shows (Figure 7b) the bacteria to begin developing on the pyrite surface along the crosswalls where the cells divide. After one and a half days of bioleaching (Figure 7c), the concentration of cells on the pyrite surface had increased, and crosswalls were easily visible. The crosswalls became visible when the cell length reached about $3 \mu \mathrm{m}$; the length of a divided cell was about $1.5 \mu \mathrm{m}$. Figure $7 \mathrm{~b}-\mathrm{c}$ shows bacterial colonization beginning to take place where a cell or several cells initially became attached. Because the cell was firmly attached to the surface, the daughter cells produced by division stayed in the same place. The correlation of the events on the pyrite surface with the CV during this period (Fig. 4b) confirms that the large amount of free pyrite surface corresponds to the presence of the stirring effect. An important observation at this point concerns some morphological changes of the cells, which were beginning to grow a product on their external walls, to be addressed later.

Figure 7d represents the pyrite surface after two days of bioleaching, the critical time when, according to cyclic voltammetry, the pyrite surface became insulated from the solution 
(Figure 4C) and no currents were produced in the characteristic region for iron redox reactions. The correlation of the CV (Figure 4c) with SEM results (Figure 7d) indicates that the pyrite surface underwent a dramatic change, becoming completely covered with a layer consisting of active bacteria las shown by the presence of crosswalls) and a product layer made up of spheres of almost identical size. Because the diameter of these spheres is about the same as the diameter of the cells, it was thought initially (17) that the round product layer was actually the cells, which, because of overcrowding, were oriented with one end toward the surface. However, this was later disproved, as discussed below.

A similar product layer was obtained after two and a half days of bioleaching (Figure 7e). At this point, mature bacteria were shorter than the bacteria from the beginning stages of growth, and the brighter ends of some of the cells indicated the changes within the cells themselves. Some of the cells were also grouped into clumps, which are more clearly seen after five days of biole-ching (Figure 7f). A few dividing bacteria can still be seen on the surface of the clumps. The surface itself appeared to be covered with a continuous layer consisting of tightly packed, individual spherical lumps.

Figure 8 a shows the product layer on the pyrite surface under low magnification (20X). The product layer was very brittle and readily peeled off after drying. Under higher magnification (1,000X; Figure 8b) the barren surface of the pyrite (lower part of photograph) with a thin product layer was seen. On top of the thin 
product layer, there is another layer consisting of spherical products.

During the SEM study of more than one hundred different pyrite surface areas it was observed that after two days of bioleaching the reaction product layer was cracked to some extent (Figure 11). The cracks explain the results of cyclic voltammetry beyond two days of bioleaching. According to Figure $5 \mathrm{a}$, the currents characteristic for iron redox reactions emerged again after three days of bioleaching, but they were independent of the effects of stirring and smaller than at the beginning stages of leaching. The absence of the effects of stirring can be explained by the presence of the electroactive species within the cracks of the product layer. Thus, the CVs of pyrite beyond two days of bioleaching represent the redox reactions of the same iron species trapped within the cracks.

\section{Chemical Analysis}

CHNos Analysis: Samples of original pyrite (control), and pyrites after two and five days of bioleaching, were scraped to prepare enough reaction product for CHNOS analysis (Table 2). It was expected that if the reaction product layer contained bacterial cells then it should also contain carbon and nitrogen. Both carbon and nitrogen were present in the product layer, which came from cell biomass. After five days of bioleaching, the cells died and were converted into a globular product that contained less carbon. Nitrogen was almost absent from the five-day sample. 
EDX: Energy Dispersive X-ray study of two phases, globular and continuous, after five days of bioleaching produced five X-ray peaks for each phase. Two peaks were characteristic of iron, one peak was characteristic of sulfur, one of potassium, and one of oxygen. The weight percent of $\mathrm{Fe}, \mathrm{S}$, and $\mathrm{K}$ is given in Table 2 .

AA: Iron from two residues was determined by atomic absorption (Table 2). One residue represented a final product after five days of bioleaching, and the other was the reaction product spared from the cyclic voltammetric study after 25 days of abiotic aeration of ferric sulfate solution, the experiment used to prepare Figure 6 .

X-Ray Diffraction: Direct $\mathrm{X}$-ray diffraction of the pyrite electrode with the original product layer failed to produce any useful information because the reaction product was too thin, and as a result, only the peaks from the underlying pyrite matrix were seen. Because the underlying matrix was a solid pyrite with a preferred orientation, a noninformative $\mathrm{x}$-ray spectrum was obtained. It was therefore decided to scrape off the reaction product layer and to perform $\mathrm{x}$-ray powder diffraction, which guarantees a random orientatior of individual crystals. The X-ray diffraction data of two biotic and one abiotic reaction products are given in Figure 9. The biotic reaction products were recovered on the fifth day of bioleaching at $\mathrm{pH} 2$ and $\mathrm{pH} 2.5$. The abiotic product was obtained from the same experimental run used for the aeration of ferric sulfate solution for 25 days (Figure 6). The Xray diffraction data of the experimental reaction products were 
found to match the $\mathrm{X}$-ray data of synthetic jarosite.

Table 2 Chemical Analysis of Reaction Product. Analysis performed by CHNOS, EDX, and Atomic Absorption(AA).

\begin{tabular}{|c|c|c|c|c|c|c|c|}
\hline Element: & $\div \mathrm{C}$ & $\div \mathrm{H}$ & $\div \mathrm{N}$ & $\div 0$ & $\div S$ & $\% \mathrm{Fe}$ & $\div \mathrm{K}$ \\
\hline \multicolumn{8}{|l|}{ METHOD: CHNOS } \\
\hline Pyrite: Control & 0.19 & - & 0.002 & - & - & - & - \\
\hline Pyrite: 2 days & 7.35 & 1.67 & 2.11 & 25.02 & 15.85 & - & - \\
\hline Pyrite: 5 days & 1.25 & 1.80 & 0.09 & 25.00 & 12.11 & - & - \\
\hline $\begin{array}{l}\text { Abiotic Residue } \\
\text { (25-day } \mathrm{Fe}^{3+} \text { aeration) }\end{array}$ & 0.08 & 1.80 & 0.00 & 25.10 & 13.27 & - & - \\
\hline $\begin{array}{l}\text { Biotic Residue } \\
\text { (5-day Bioleaching) }\end{array}$ & 0.08 & 2.40 & 0.00 & 25.00 & 6.00 & - & - \\
\hline \multicolumn{8}{|l|}{ METHOD: EDX } \\
\hline $\begin{array}{l}\text { Globular Phase } \\
\text { Continuous Phase }\end{array}$ & - & - & - & $\begin{array}{l}- \\
-\end{array}$ & $\begin{array}{l}20.60 \\
19.70\end{array}$ & $\begin{array}{l}37.6 \\
36.9\end{array}$ & $\begin{array}{l}1.9 \\
0.9\end{array}$ \\
\hline \multicolumn{8}{|l|}{ METHOD: AA } \\
\hline $\begin{array}{l}\text { Abiotic Residue } \\
\text { (25 days } \mathrm{Fe}^{3+} \text { aeration) }\end{array}$ & - & - & - & - & - & 31.5 & - \\
\hline $\begin{array}{l}\text { Biotic Residue } \\
\text { (5-day Bioleaching) }\end{array}$ & - & - & - & - & - & 37.5 & - \\
\hline
\end{tabular}

Theoretical Compositions of Jarosite

$\begin{array}{llllllll}\text { (K) } \mathrm{Fe}_{3}\left(\mathrm{SO}_{4}\right)_{2}(\mathrm{OH})_{6} & - & - & - & 44.7 & 12.8 & 33.5 & 7.8 \\ (\mathrm{H}) \mathrm{Fe}_{3}\left(\mathrm{SO}_{4}\right)_{2}(\mathrm{OH})_{6} & - & - & - & 48.4 & 13.8 & 36.2 & -\end{array}$


ray and chemical characterization of the reaction products obtained during leaching in the bacterial growth stage, a mechanism by which I. ferrooxidans cells serve as the nucleation sites for the formation of jarosite is proposed. The $\mathrm{x}$-ray data are the strongest evidence for jarosite formation, and the chemical analyses also lead toward the same conclusion. For example, the sulfur content of the reaction product is in excellent agreement with the theoretical amount according to the CHNOs analysis (Table 2), and the iron content is in theoretical agreement according to the atomic absorption and EDX analyses. Some discrepancy exists with respect to the oxygen and sulfur composition obtained by the CHNOS and the EDX analyses, respectively. The lower-thantheoretical content of oxygen can be explained by a deficiency of the method used for analyzing oxygen by the CHNOS analyzer, which cannot break the $\mathrm{SO}_{4}$ group during pyrolysis. The somewhat higher sulfur content according to the EDX analysis is perhaps the consequence of analyzing too small an area, and only on the surface.

According to the proposed mechanism (Figure 10), jarosite formation begins on a cell. With time, the initial nuclei of jarosite grow, and new nucleation sites are initiated, as shown by examination of Fiçure 7a-f. Several of the nucleation sites are marked by the arrows on the cells after one day (Figure 7b) and one and a half days of bioleaching (Figure 7c). During the formation of jarosite, the cells suffer drastic changes that cause their eventual collapse. The development of globular areas can be 
identified by the presence of several lines perpendicular to the length of the cells. The crosswalls along which the cell will divide during multiplication are clearly distinguished from the division lines along which the cell will eventually collapse and break into spherical products. This is best seen in Figure 11, which represents (at 15,000x magnification) two different areas of the same pyrite sample after 48 hours of bioleaching. The left photomicrograph demonstrates a typical agglomeration of individual cells. Each cell within this agglomerate is in the process of transformation into the final reaction product, jarosite. The final result will be a larger globe, such as those routinely observed on the pyrite surface after bioleaching, for example in Figure $7 \mathrm{e}$ and $7 \mathrm{f}$. If the cells are not agglomerated, or only a few cells are involved, then the final reaction product will be smaller globular products. In either case, the cell eventually collapses completely as it is transformed into jarosite.

Ivarson (18) and Ivarson at al. (19) found that oxidation of ferrous sulfate by the organisms in liquid medium resulted in the formation of jarosite. Lazaroff et al. (20), and Lazaroff (21) found, according to chemical composition and infrared spectra, that amorphous ferric hydroxysulfates were predominant at higher $(3.5$ to 5), while jarosites were predominant at lower $\mathrm{Fe}^{3+} / \mathrm{SO}_{4}{ }^{2-}$ (about 1.5 ) ratios. They also found that jarosite formation even continued long after all bacteria had been removed from the system and oxidation had ceased. The prolonged formation of jarosite (cell free system) was explained by the bacterial generation of organic 
products which formed iron hydroxo-sulfato complex intermediates before these were converted into ferric hydroxysulfate polymers. After that, depending upon the ionic environment, the iron complex precipates by forming amorphous ferric hydroxysulfates (low $\mathrm{SO}_{4}{ }^{2-}$, presence of $\mathrm{Cl}^{-}, \mathrm{NO}_{3}^{-}$, etc.), or crystalline jarosites (presence of $\mathrm{NH}_{4}^{+}, \mathrm{K}, \mathrm{Na}$, and excess of $\mathrm{SO}_{4}{ }^{2-}$ ). According to Toro et al. (22), the first phase of ferrous iron biooxidatjon, within $12 \mathrm{~h}$, is characterized by formation of amorphous $\mathrm{Fe}(\mathrm{OH})_{3}$, followed by jarosite precipitation, after $24 \mathrm{~h}$ (characterized by $\mathrm{X}$-ray diffraction).

The present work suggests that the composition of solution has to be characterized on the discrete and localized level (on a cell or in the vicinity of a cell) too. Because a cell is the place were ferric iron is formed, the concentration of ferric iron is higher on cells than in the bulk of solution. The same is true with the released organic compounds. The releasing organic compounds would form with ferric iron, the complexes, which would further be converted into jarosite products due to the presence of monovalent cations $\left(\mathrm{K}^{+}\right.$and $\left.\mathrm{NH}_{4}^{+}\right)$from medium salts. The ferric iron that escaped the cell and its vicinity may still be converted into jarosite in the bulk of solution. Because of lower concentration of reactants in the bulk than on the cells, the rate of jarosite formation in the bulk would be lower than the rate of jarosite formation on the cells. For this reason, the bacterial cells would appear to serve as the nucleation sites for jarosite formation. With time, the jarosite formation on the cells would advance, 
causing either encapsulation of the cells into the reaction product or a total collapse of the cells. 

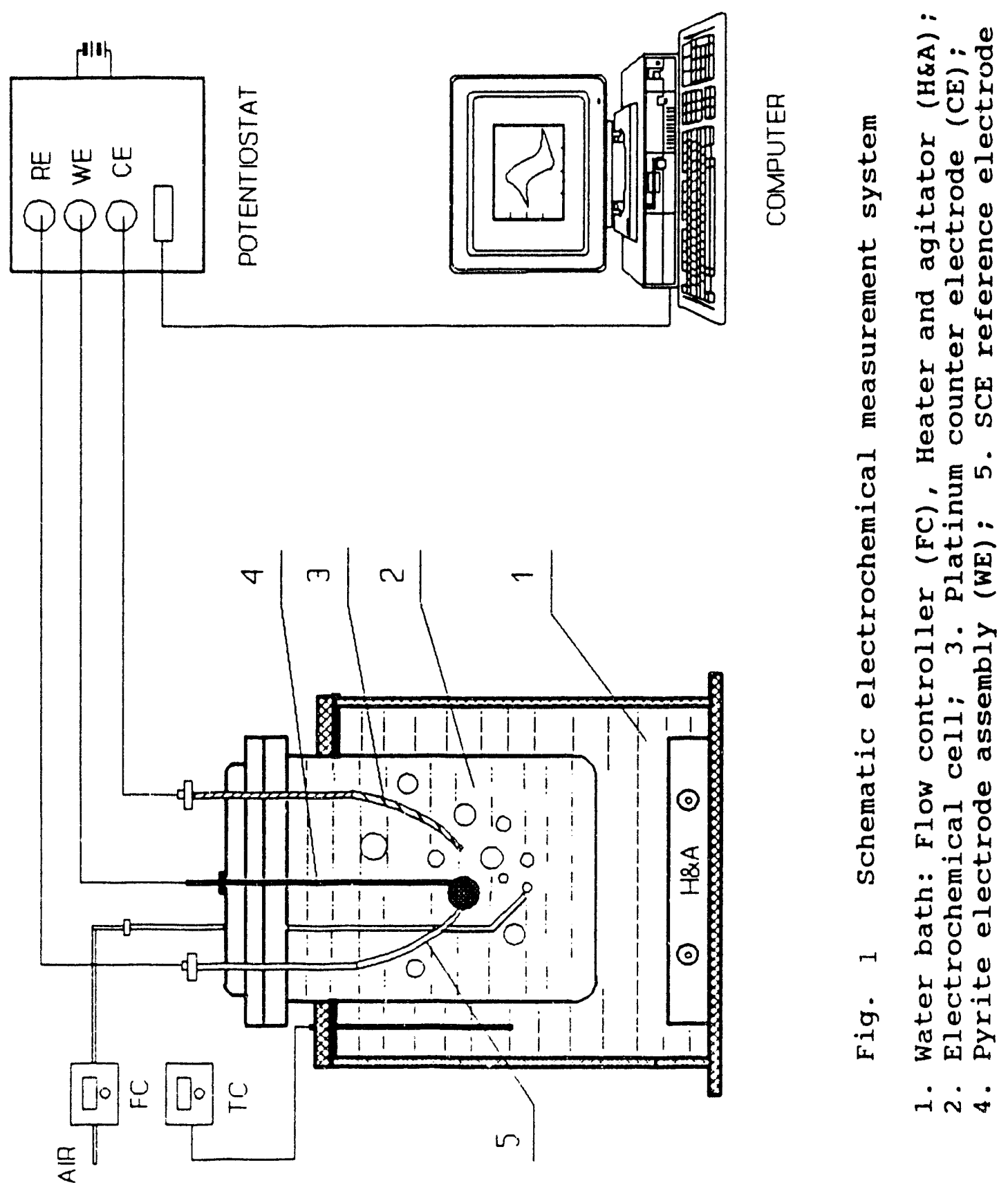


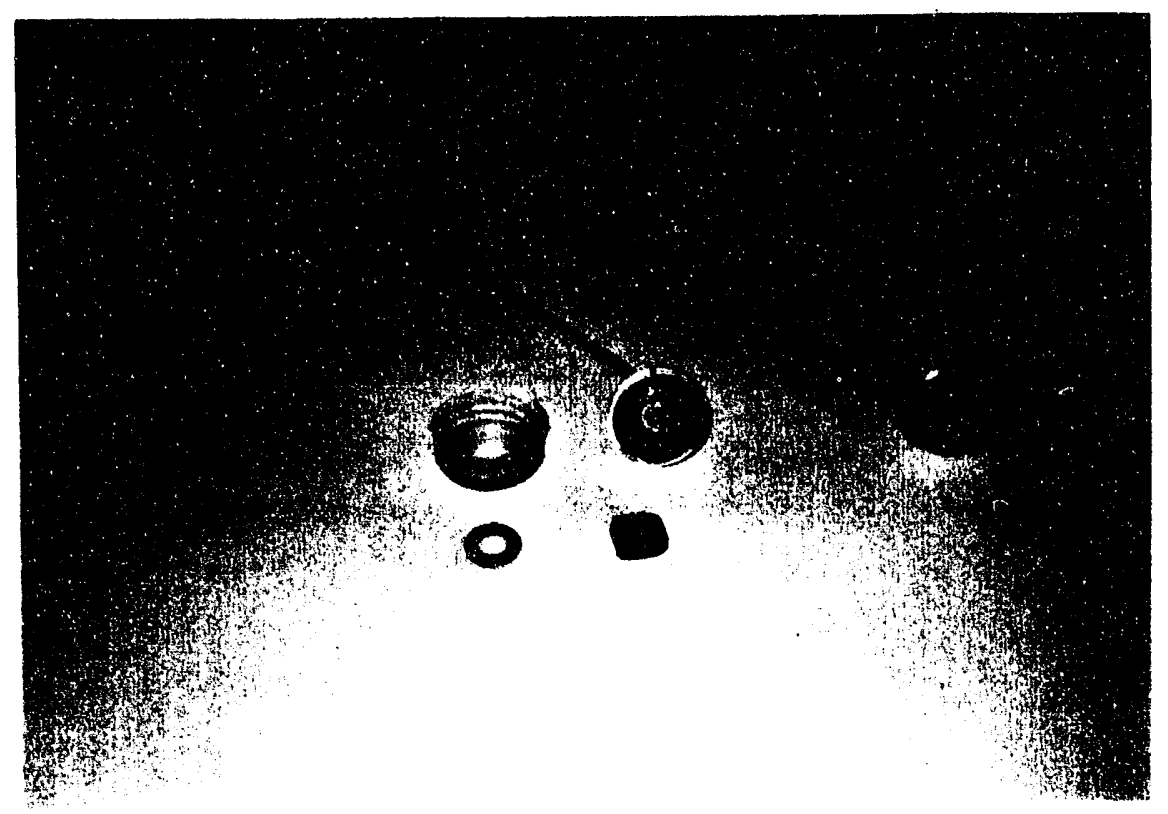

Fig. 2 A disassembled and an assembled pyrite working electrode. 

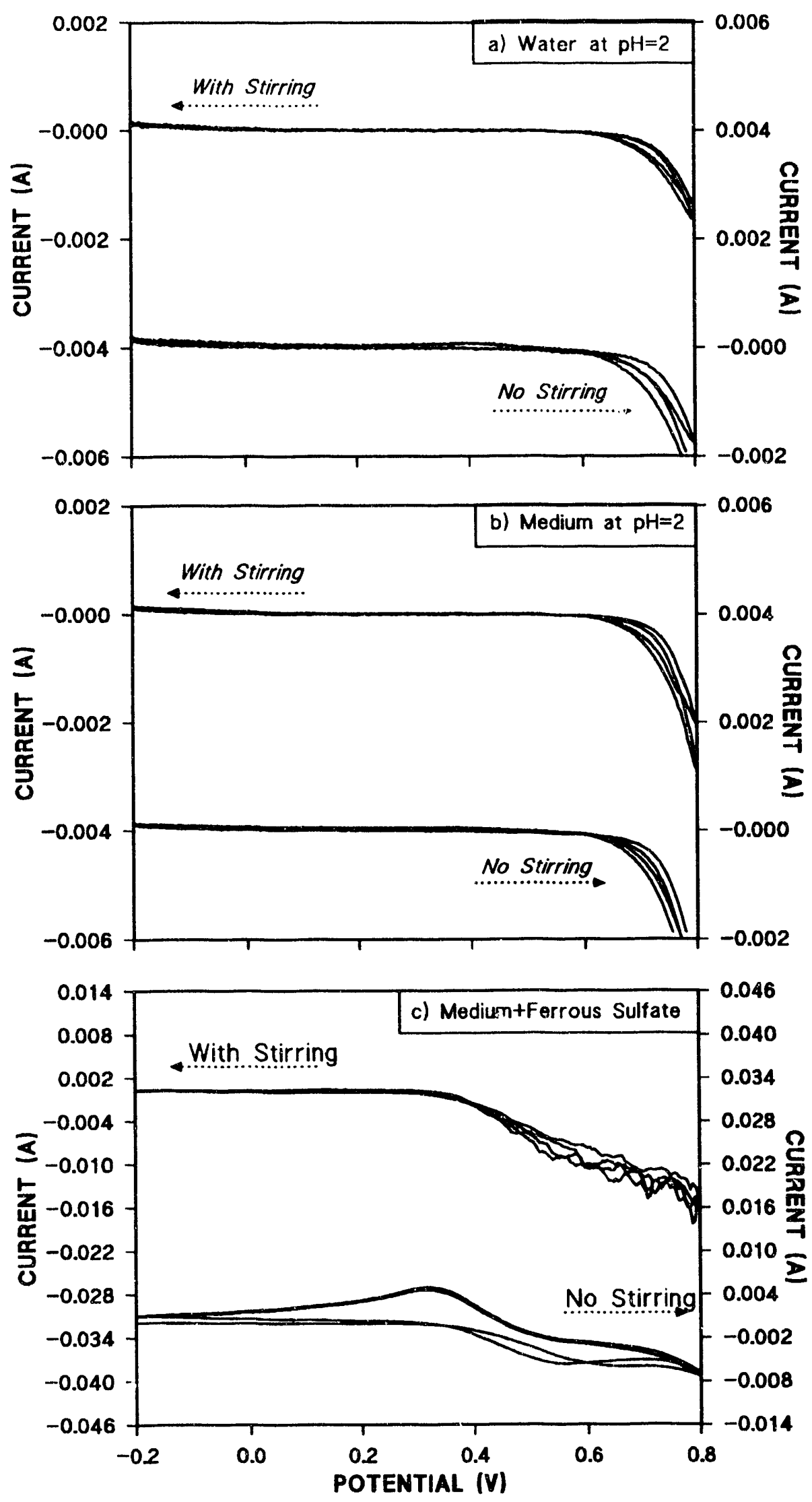

Fig. 3a-c Cyclic voltammograms of pyrite in the abiotic system: a) water at pH 2, b) water at $\mathrm{pH} 2$ to which medium salts were added, c) in the presence of medium + ferrous sulfate. 

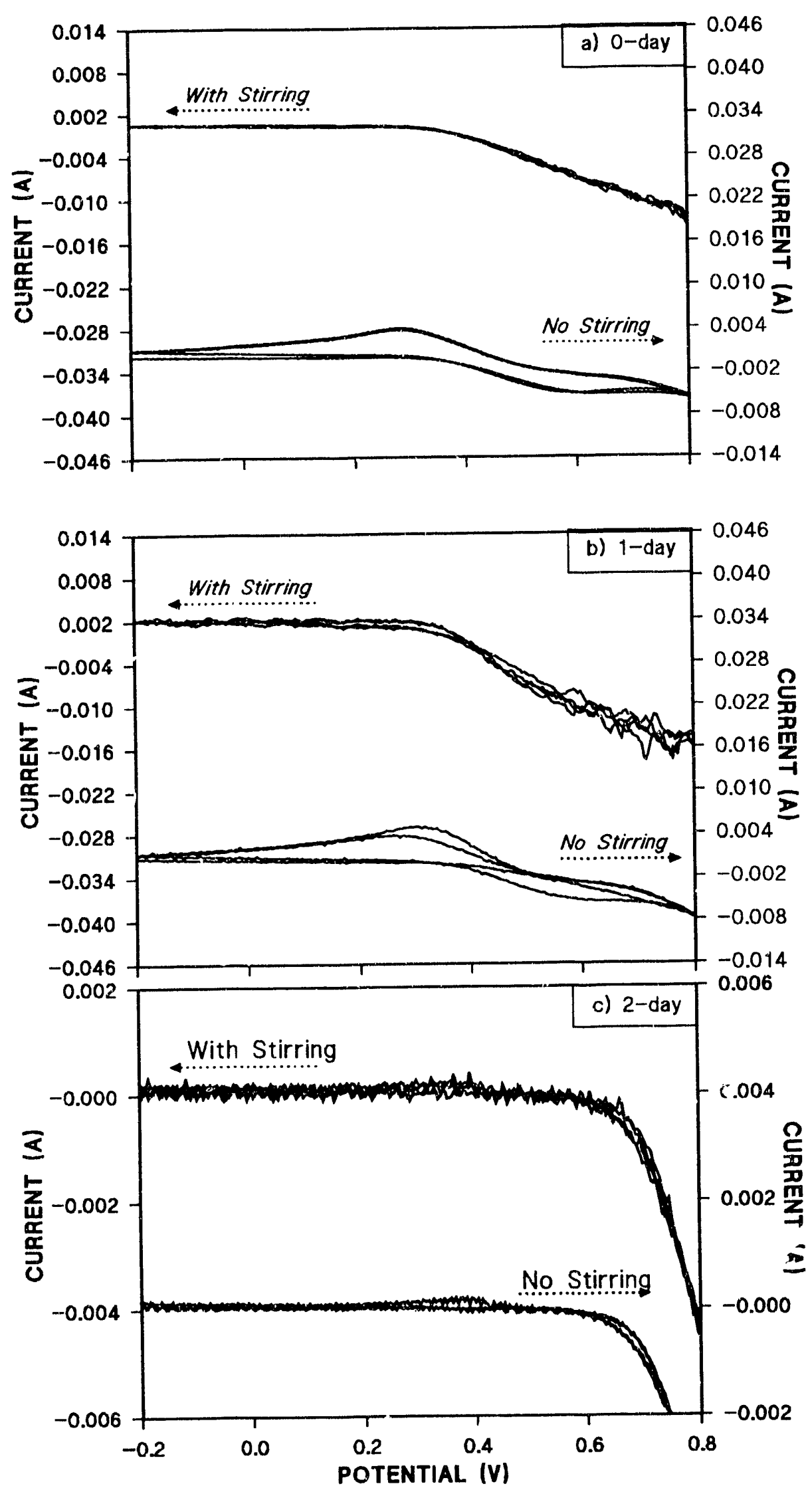

Fig. 4a-c Cyclic voltammograms of pyrite as a function of time in the biotic system:

a) at the beginning, day- 0, b) after 1 day of bioleaching, c) after 2 days of bioleaching. 

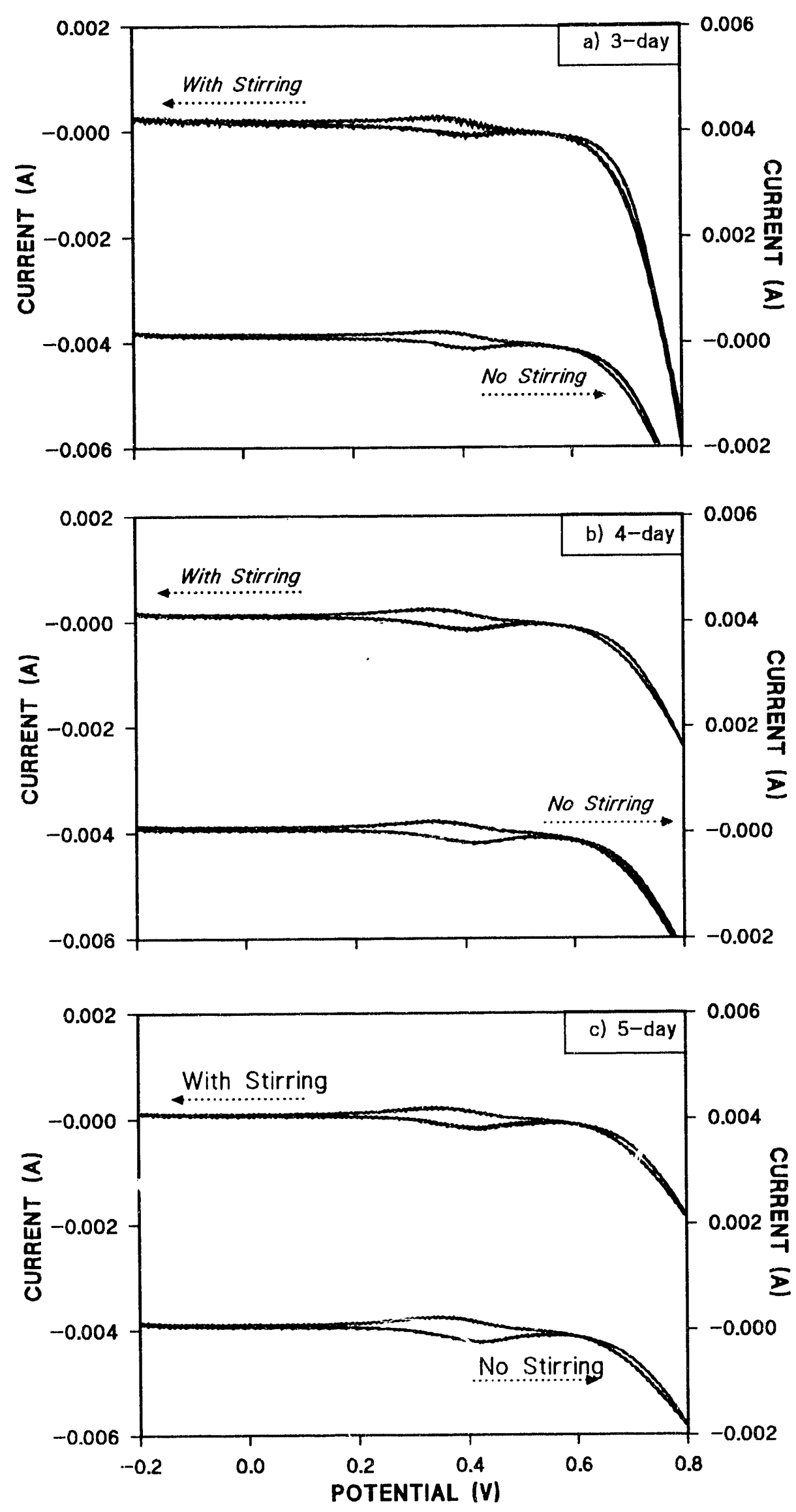

Fig. 5a-c Cyclic voltammograms of pyrite as a function of time in the biotic system: a) after 3 days, b) after 4 days, c) after 5 days of bioleaching. 


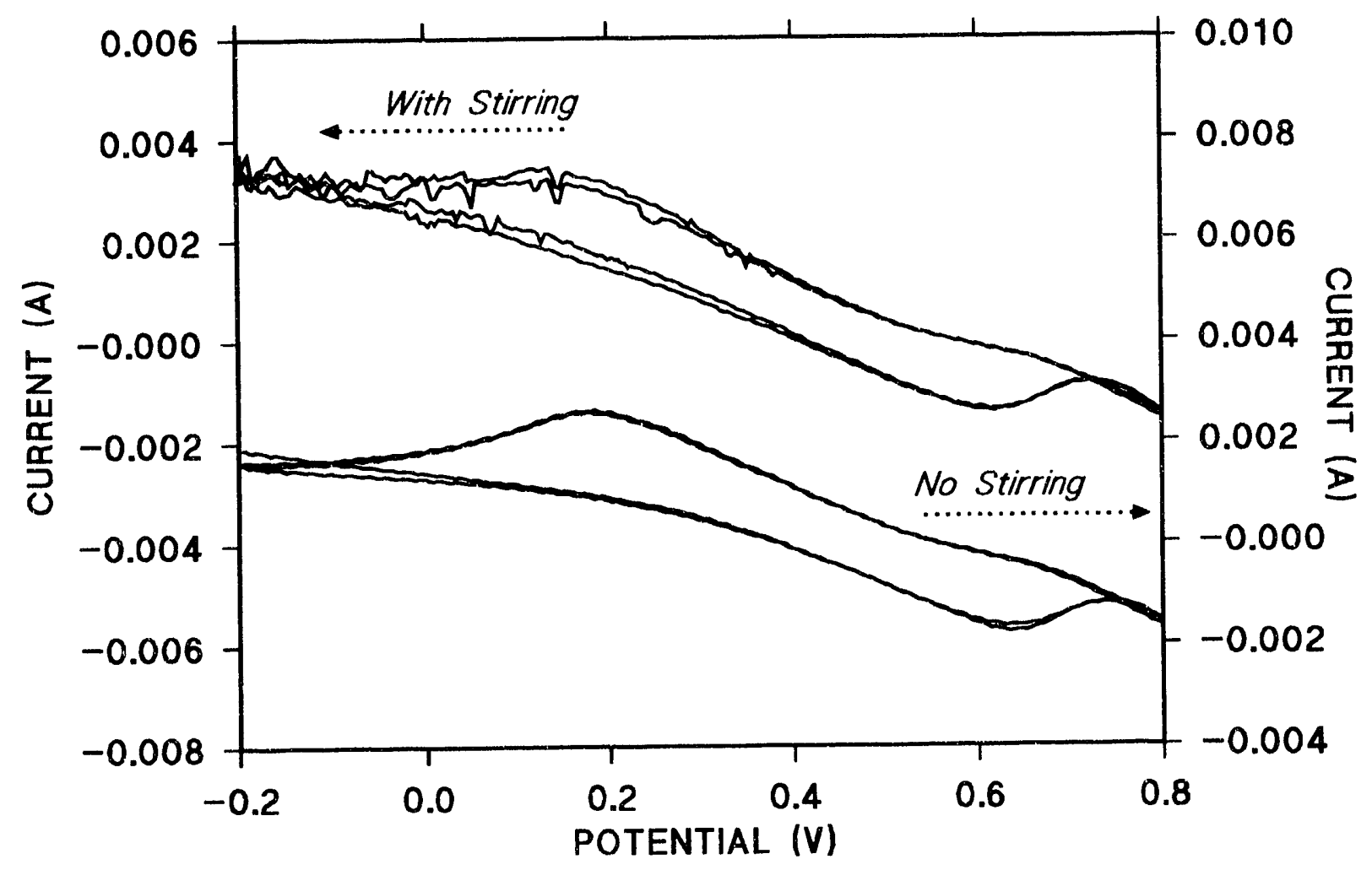

Fig. 6 Cyclic voltammetry of pyrite after 25 days of exposure to abiotic ferric sulfate solution. 
Fig. 7a-f SEM photomicrographs of pyrite surface during bioleaching with $\mathrm{T}$. ferrooxidans in the growth stage: a) 2hrs; b) 1-day; c) 1.5-day; d) 2-day; e) 2.5-day and f) 5-day. The arrows in (b) and (c) identify some of the cells and the locations where jarosite product formation initiates. 


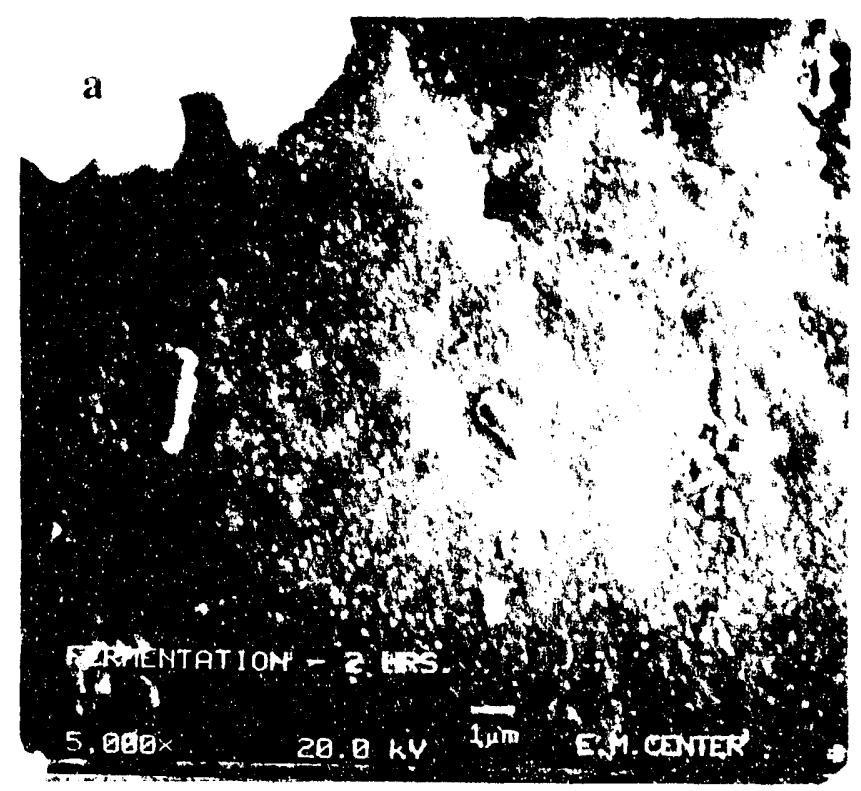

(b)

1)
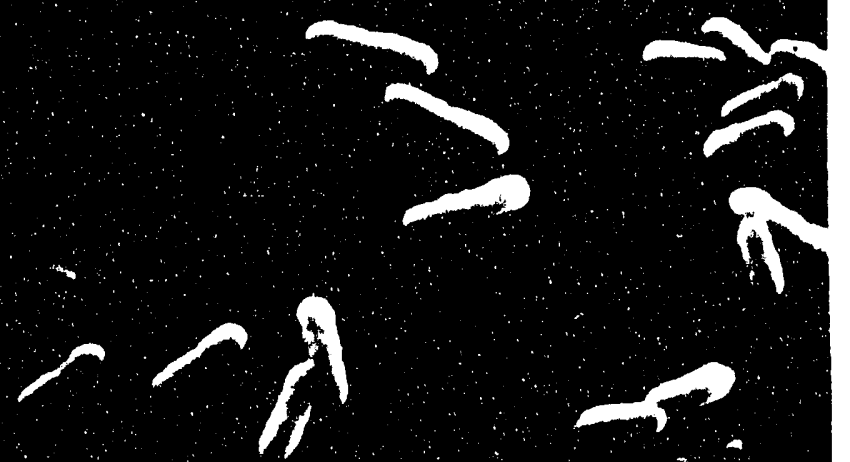

(1)

FERMENTATION - 1 DAY

- $5.000 \times$ 20.0 kV $1 \mu \mathrm{m}$ E.M.GENTER

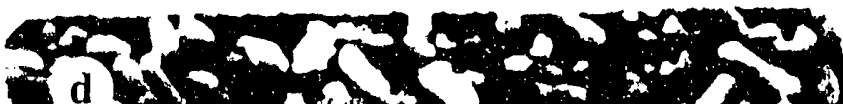
d d a d a 14

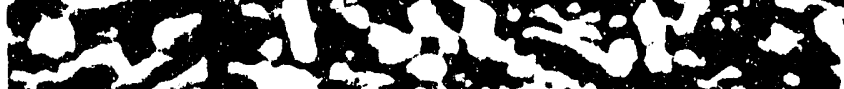

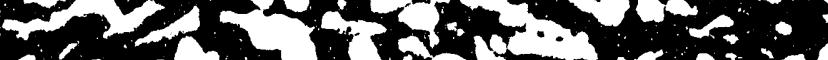

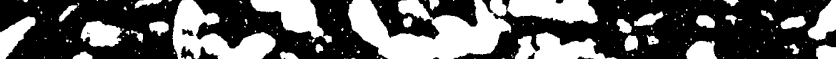

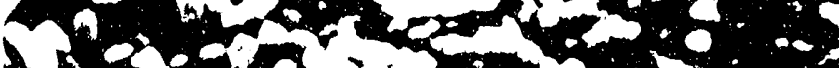

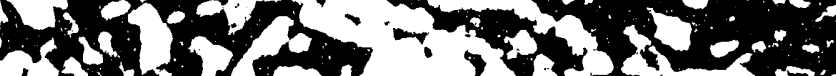

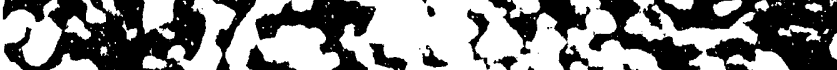

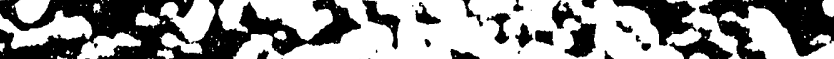

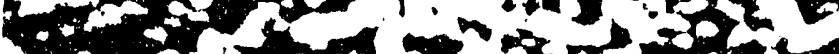

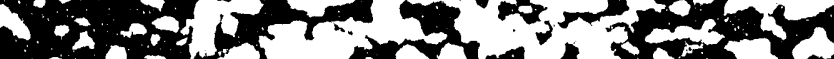

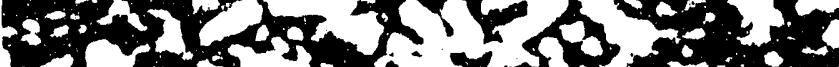

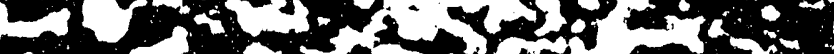

(1)

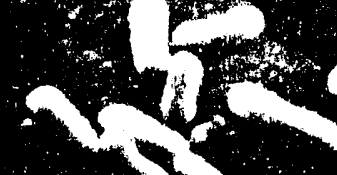

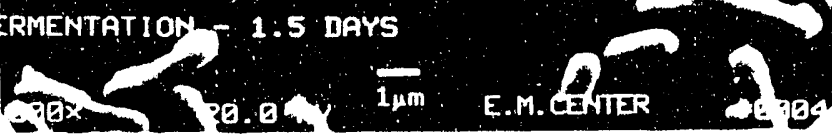

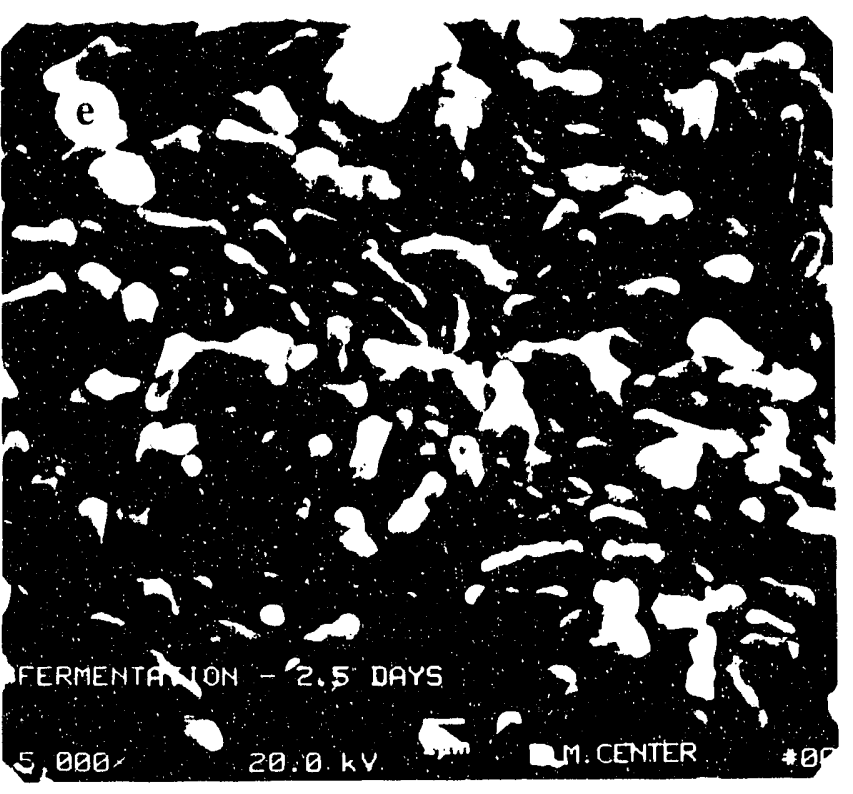

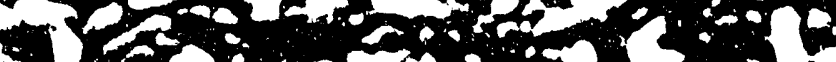

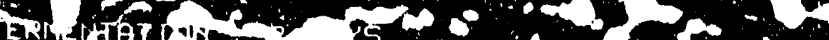
$c$ - - -

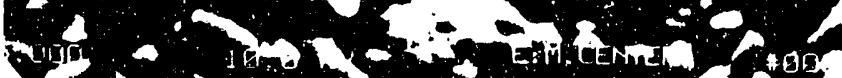

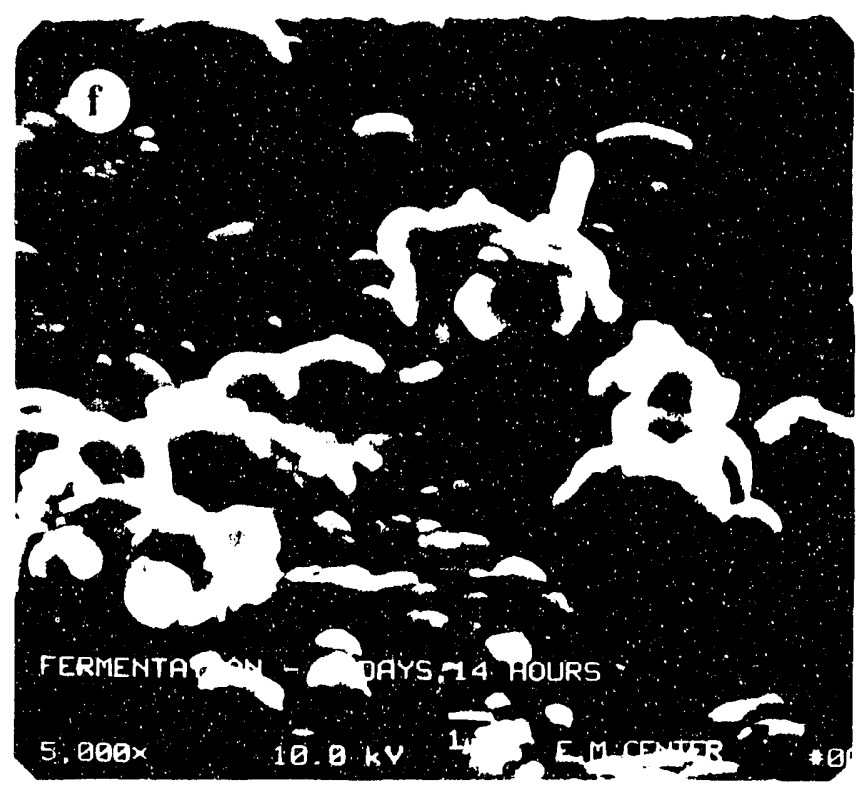



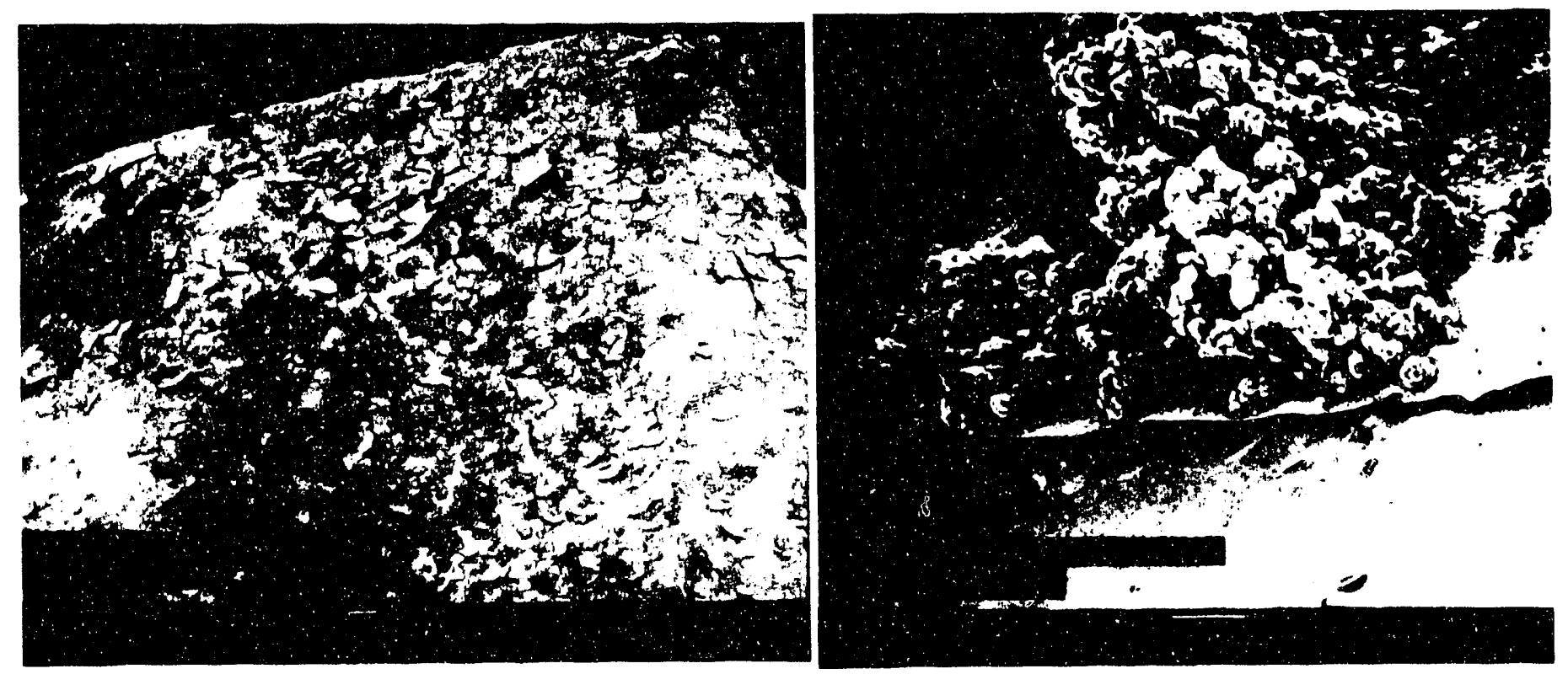

Fig. 8a-b SEM of pyrite surface after 5-day fermentation of $\mathrm{T}$. ferrooxidans.

a) Low magnification: 50x. Notice the product layer. It is brittle when dry and readily peels off.

b) A particular segment of a product layer presented (a) except magnified $1000 \mathrm{x}$.

A feature to notice is blanket of a continuous layer on pyrite surface (somewhat separated from the surface perhaps because of drying). On top of a continuous blanket layer there is a massive deposition of globular reaction products. Careful inspection can also identify many "intact" bacteria cells in the continuous layer. 

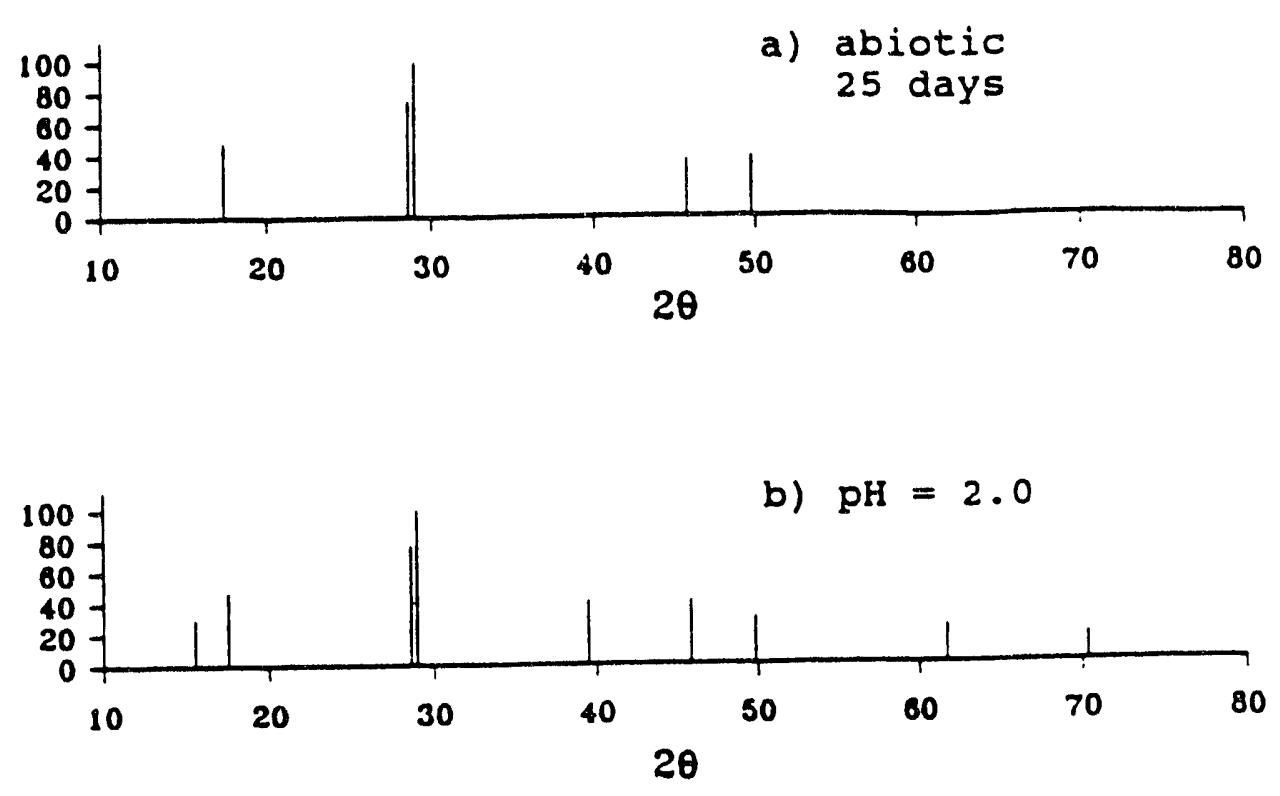

c) $\mathrm{pH}=2.5$

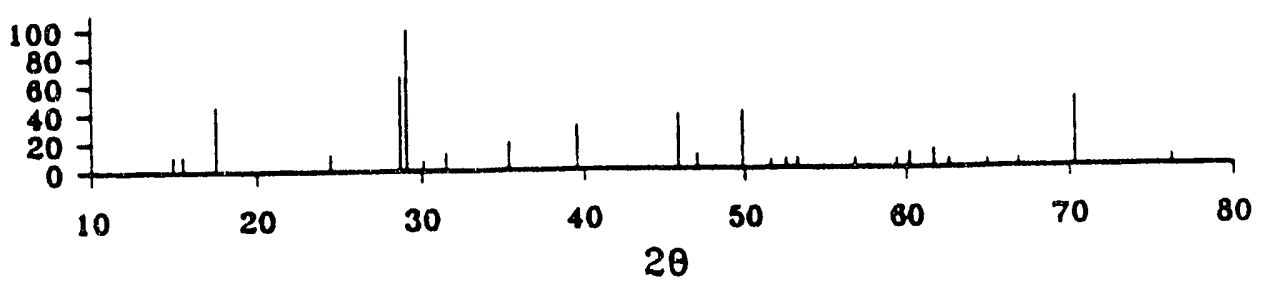

d) $\mathrm{KFe}_{32}\left(\mathrm{SO}_{4}\right)_{2}(\mathrm{OH})_{6}$

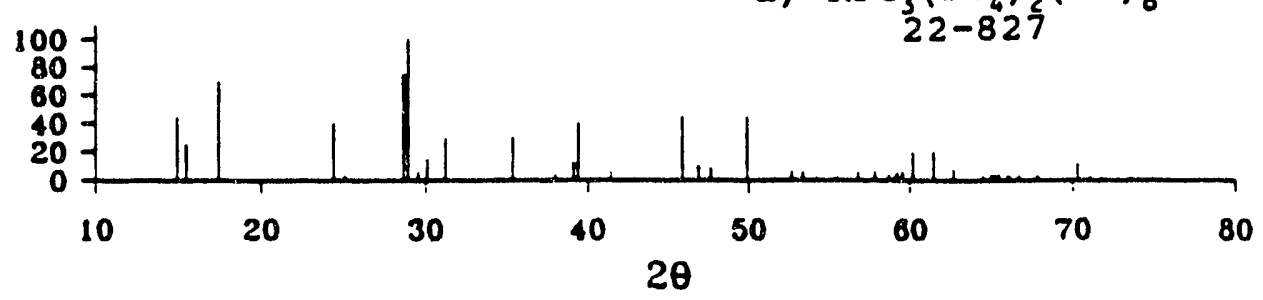

Fig. 9 x-ray diffractograms obtained with:
a) reaction product formed during abiotic oxidation of ferric with air ( 25 days)
b) reaction product after 5 days of fermentation at $\mathrm{pH}=2$
c) reaction product after 5 days of fermentation
d) synthetic jarosite (ASTM 22-827). 


\section{CELL DIVISION}
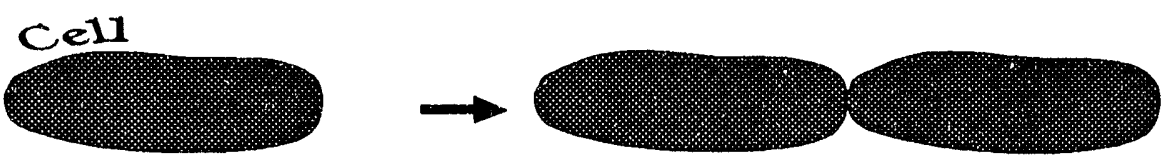

\section{JAROSITE NUCLEATION AND GROWTH $(\mathrm{K}) \mathrm{Fe}_{3}\left(\mathrm{SO}_{4}\right)_{2}(\mathrm{OH})_{0}$}

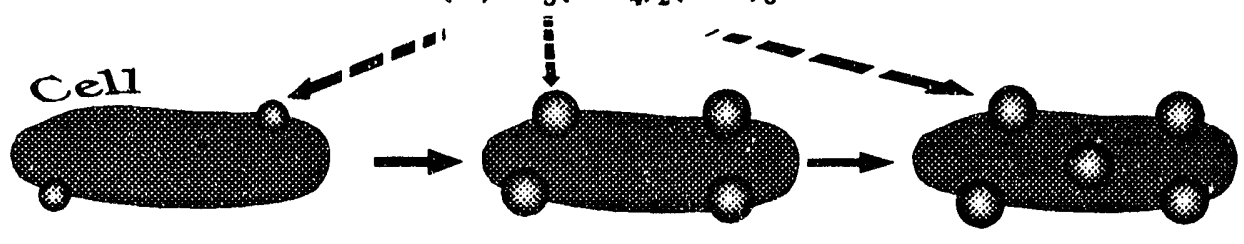

\section{CELL COLLAPSE AND FINAL JAROSITE FORMATION}

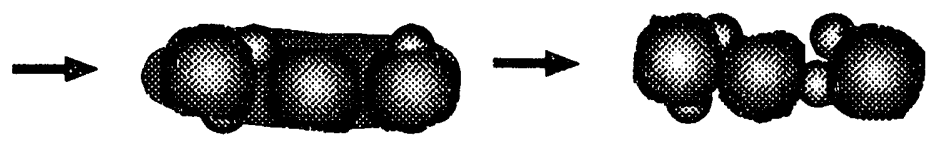

Fig. 10 Schematic representation of jarosite nucleation on the cells, jarosite growth, and final cell collapse observed during bioleaching with $\mathrm{T}$. ferrooxidans in the growth stage. The early nucleation sites can be recognized on some of the cells in Fig. 7b (1-day) and Fig. 7c (1.5-days). Near cell collapse can be seen in Fig. 11 below. 


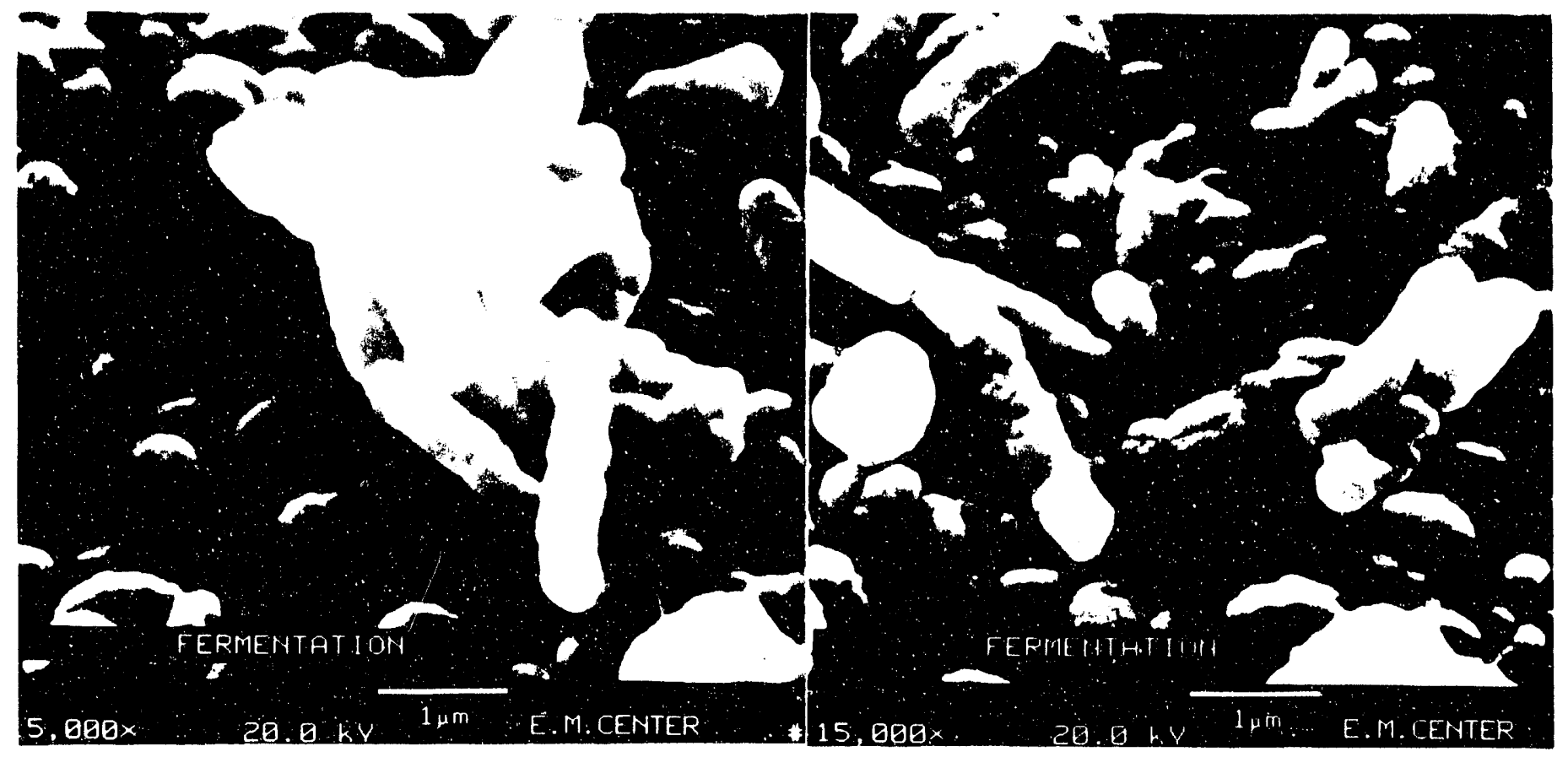

Fig. 11 SEM photomlcrographs of $T$. ferrooxidans cells from two different pyrite areas at much higher magnification, 15, 000X. Inspection of individual cells reveals distinct lines along which the cells will collapse into an agglomerate of small globular. products. The left photo also demonstrates the agglomeration of many individual bacterial cells, the final fate of which will be the transformation into a large globe 
CHAPTER II

\section{EFFECT OF HEAVY METALS ON THE IRON OXIDIZING ABILITY OF Thiobacillus ferrooxidans}

\section{INTRODUCTION}

Because of its great technological potential, bioleaching by means of Thiobacillus ferrooxidans and other autotrophic bacteria has received much attention $(23,24)$ over the past few decades. For example, microbial oxidation has already been seen to be useful. for liberating precious metals, especially gold, locked in the refractory sulfide matrix, and thereby rendering cyanidation in heap leaching possible (25). Bioleaching has been reported (25, 26) to be applicable for dump leaching of low-grade refractory copper ores such as CuFes 2 . Recently (27-28), bioleaching has been considered for use in removing pyritic sulfur from coal and in helping to control environmental pollution (i.e., acid rain caused by $\mathrm{SO}_{2}$ emission from coal-fired power plants).

An evaluation of the literature reveals that the role of $\mathrm{T}$. ferrooxidans in the bioleaching of mixed metal sulfides is to catalyze the oxidation of iron sulfide(s) to Fe(III) sulfate. However, previous work does not specify which component of the microbial cell plays the key role in bioleaching. Earlier reports $(31,42)$ have cited that a type c cytochrome may be responsible for the transport of electrons from Fe(II) to oxygen, while a more recent communication (33) has mentioned that a $92 \mathrm{~K}$ glycoprotein may be the most important component of the Fe(II) oxidizing system of T. ferrooxidans. While there is a lack of agreement regarding the 
identity of the microbial enzyme effective for Fe(II) (or sulfur) oxidation, two alternative mechanisms are suggested for the microbial leaching of metal sulfides. According to the direct mechanism, physical contact between the bacteria and the sulfide mineral surface is required (44). In the indirect mechanism, the bacterially generated Fe(III) acts as a lixiviant for the solubilization of metals from the mineral $(25,26)$. In actual fact, however, both of the mechanisms may operate simultaneously in a complementary manner.

An important side effect of bioleaching may be co-dissolution of other heavy metal ions, which, if accumulated to a certain level, may influence the activity of the $\mathrm{T}$. ferrooxidans cells. In a more drastic case, the heavy metals may kill the bacteria and thus stop bioleaching. On the other hand, some heavy metals may exert an inhibitory effect on bioleaching by deactivating bacteria, the living catalysts. The deactivation process may involve blocking or damaging a significant fraction of the active sites on the microbial enzyme(s) by heavy metal ions. In another possible deactivation process, the presence of a particular heavy metal may enhance the formation of toxic species from dissolved oxygen, e.g., $\mathrm{O}_{2}{ }^{-}$. Oxygen toxicity through the superoxide (i.e., $\mathrm{O}_{2}^{--}$) formed in the biological systems has already beefn described in the literature (35).

Tuovinen and Kelly (36) have studied the effect of $\mathrm{UO}_{2}{ }^{2+}$ on the iron oxidation by Thiobacillus ferrooxidans. It was found that the presence of $\mathrm{UO}_{2}{ }^{2+}$ species partially inhibited the oxidizing 
activity of the bacteria by blocking the active sites in the cell. The addition of a complexing agent like EDTA or a nontoxic cation (e.g. $\mathrm{Mg}^{2+}$ ) reduces the inhibitory action due to the uranyl cation. Imai et al. (31) found that mercuric and mercurous ions are even more toxic than uranyl or any other heavy metal ions studied, e.g., lead, arsenic, zinc, molybdenum, copper, cadmium, etc. The observed variation in the toxicity of heavy metals might have resulted from differences in the modes of interaction between the cell enzyme(s) and various heavy metal ions. These findings suggest the likelihood that $\mathrm{UO}_{2}{ }^{2+}$ may be physically sorbed onto the cell so that it can be easily exchanged with a divalent cation such as $\mathrm{Mg}^{2+}$. On the other hand, $\mathrm{Hg}(\mathrm{II})$ may more strongly interact with the ferrous iron oxidizing system of T. ferrooxidans (31). Thus, combination with the iron oxidase and the enzyme-substrate complex may take place when mercury is present in the system.

Silver, another heavy metal, is often cited as toxic to $\underline{T}$. ferrooxidans $(31,37-40)$. For example, previous workers $(38,39)$ have reported that in an aqueous $\mathrm{FeSO}_{4}$ solution of low $\mathrm{pH}$, growth of $T$. ferrooxidans is decreased and its ferrous iron oxidizing ability is significantly decreased by the presence of approximately $0.10 \mathrm{mg} / \mathrm{L} \mathrm{Ag}{ }^{+}$. Hcwever, if a metal sulfide, e.g., CuFes, is used in the solid form as the bacteria's sole nutrient, then the presence of a significant quantity of silver may not harm the metal sulfide bioleaching activity of the bacteria (41-43). Indeed, the bioleaching of CuFeS $_{2}$ is seen to be enhanced at $\mathrm{pH} 1.25$ in the presence of $30 \mathrm{mg} / \mathrm{L} \mathrm{Ag}^{+}$(43). The positive catalytic effect of 
silver ions is explainable $(41,43,44)$ in terms of the formation of $\mathrm{Ag}_{2} \mathrm{~S}$, which is thermodynamically more stable than $\mathrm{CuFeS}_{2}$. Since $\mathrm{Ag}^{+}$is a small cation, it is able to diffuse into the CuFes crystal $_{2}$ to take part in the following surface reaction:

$$
\mathrm{CuFeS}_{2}+4 \mathrm{Ag}^{+}-\ldots->2 \mathrm{Ag}_{2} \mathrm{~S}+\mathrm{Cu}^{2+}+\mathrm{Fe}^{2+}
$$

$\mathrm{Fe}$ (III) may regenerate $\mathrm{Ag}^{+}$in accordance with the following surface reaction (44):

$$
\mathrm{Ag}_{2} \mathrm{~S}+2 \mathrm{Fe}^{3+}-\cdots 2 \mathrm{Ag}^{+}+2 \mathrm{Fe}^{2+}+\mathrm{S},
$$

In light of the literature cited above, it is conceivable that the apparent dual role of silver in the ferrous iron oxidizing ability of $\mathrm{T}$. ferrooxidans is due to differing experimental conditions. Consequently, it was decided to study the effect of silver ions on the iron oxidizing activity of $\underline{T}$. ferrooxidans by extending the experimental parameters beyond those considered in the earlier investigations. Results to date are reported here and compared with the observed effects of some other heavy metal ions (e.g. $\mathrm{Hg}^{2+}$ ) on the iron oxidizing activity of the bacteria.

\section{MATERIALS AND METHODS}

\section{Materials and Equipment}

The equipment and the method of growing T. ferrooxidans 
(strain ATCC 13598) were as reported previously (15). Only reagent. grade chemicals were used.

\section{Procedure}

\section{Experiments Without Heavy Metals}

Deionized water, $250 \mathrm{~mL}$, of a desired $\mathrm{pH}$ was transferred into the bioreactor, to which $25 \mu \mathrm{L}$ of $1 \mathrm{M} \mathrm{Fe}_{2}\left(\mathrm{SO}_{4}\right)_{3}$ and $250 \mu \mathrm{L}$ of $1 \mathrm{M} \mathrm{FeSO}$ were added. The biooxidation of $\mathrm{Fe}(\mathrm{II})$ was initiated by the addition of $2 \mathrm{~mL}$ of concentrated $\mathrm{T}$. ferrooxidans cells. The chemical activity of the bacteria was monitored by measuring the redox potential (vs SCE) of the solution. A specially built pyrite electrode served as the indicator electrode.

\section{Experiments With Heavy Metals}

The experimental procedure was similar to that in the preceding section, except that a desired concentration of a heavy metal (e.g., silver) was added before bacteria were added to the system.

To study the effect of conditioning the bacteria with silver, $2 \mathrm{~mL}$ of concentrated bacteria was added to a solution (250 $\mathrm{mL}$ ) containing silver $(1-10 \mathrm{mg} / \mathrm{L})$. When the conditioning period (5-120 min) was completed, the amounts of ferrous and ferric iron required to make $0.001 \mathrm{M}$ and $0.0001 \mathrm{M}$, respectively, in a $250-\mathrm{mL}$ reactor were added and recox potential monitoring was started. This procedure was repeated with $\mathrm{Hg}$ (II) to study the effect of mercury on the Fe(II) oxidizing activity of $\mathrm{T}$. ferrooxidans. 
Standard Experimental Conditions

The iron oxidizing activity of Thiobacillus ferrooxidans has been studied under a variety of experimental conditions. The standard conditions are:

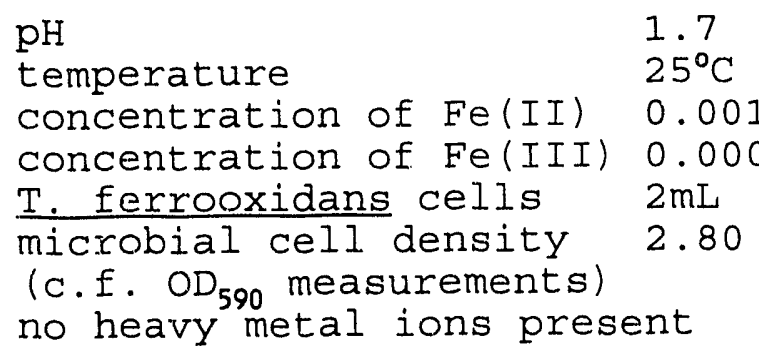

Two parallel sets of experiments were conducted, one with and the other without a heavy metal, to demonstrate the effect of the heavy metal on the activity of the $\mathrm{T}$. ferrooxidans.

\section{RESULTS AND DISCUSSION}

\section{Results of Experiments Without Heavy Metals}

\section{Effect of $\mathrm{pH}$}

The effect of $\mathrm{pH}$ on the change in redox potential as a function of time is shown in Fig. 12. The family of potential versus time curves represented by $F^{\prime} \mathrm{g} .12$ satisfies the Nernst equation, with the standard potential of $0.4324 \mathrm{~V}$ and slope of $0.055 \mathrm{~V}$ (equation 1). According to the Nernst equation (15),

$$
E=0.4324+0.055 \log \{[\mathrm{Fe}(\mathrm{III})] /[\mathrm{Fe}(\mathrm{II})]\}
$$


an increase in electrode potential results from an increase in the ferric iron activity, which is caused by the oxidation of Fe(II) by T. Eerrooxider .. The Nernst equation can be used to calculate the rate constant of the reaction (15). The results presented in Table 3 suggest that the Fe(II) oxidizing activity of the bacteria is significantly influenced by the snlution $\mathrm{pH}$. The $\mathrm{T}$. ferrooxidans cells are most active in the $\mathrm{pH}$ range $1.7-2.0$.

Table 3 Effect of $\mathrm{pH}$ on the observed rate constant of the microbial oxidation of ferrous iron.

$\begin{array}{cc}\text { pH } & \left.\text { Rate constant (min }{ }^{-1}\right) \\ 1.2 & 0.0270 \\ 1.4 & 0.0520 \\ 1.5 & 0.0570 \\ 1.7 & 0.0600 \\ 1.9 & 0.0610 \\ 2.0 & 0.0590 \\ 2.1 & 0.0500 \\ 2.5 & 0.0350 \\ 3.0 & 0.0150 \\ 3.5 & 0.0050\end{array}$

Effect of Cell Concentration

T. ferrooxidans absorbs visible light at 590nm (34). This property was used to establish a correlation between the reaction rate constant and the cell concentration of $\mathrm{T}$. ferrooxidans. At first, optical densities of the bacterial cells of various concentrations at $590 \mathrm{~nm}\left(\mathrm{OD}_{590} \mathrm{~s}\right)$ were measured. Subsequently, the corresponding concentrations of the bacteria were used in ferrous 
iron oxidation experiments (under the standard conditions described above) to determine the rate constants from the measured change of redox potential with time (15). According to the results represented by Fig. 13, Fe(II) oxidation with T. ferrooxidans is a first-order reaction with respect to the concentration of the bacteria up to $\mathrm{OD}_{590}=2.82$.

\section{Effect of Fe(II) Concentration}

Three series of experiments were performed, with concentrations of $\mathrm{T}$. ferrooxidans cells given by $\mathrm{OD}_{590}=1.41,2.8$, and 5.85. Using fluorescence microscopy to count the bacteria (45), we have found that $2 \mathrm{~mL}$ bacteria of $O D_{590}=1.41,2.8$, and 5.85 corresponds to approximately $7.72 \times 10^{9}, 15.44 \times 10^{9}$, and 32.26 $x 10^{9}$ cells, respectively. In each series of experiments, parameters other than Fe(II) concentration were held constant. The results are represented by the curves with closed symbols in Fig. 14. In general, the curves representing rate constant versus concentration of $\mathrm{Fe}$ (II) were seen to shift towards the right as the microbial cell density is increased from $\mathrm{OD}_{590}=1.41$ to $\mathrm{OD}_{590}=5.85$ (Fig. 14). To explain this observation, the data represented by Fig. 14 (closed symbols) were reprocessed to obtain Fig. 15 and 16. Fig. 15 shows the variation of the initial rate of Fe(II) oxidation by $T$. ferrooxidans as a function of $F e(I I)$ concentration corresponding to three microbial cell densities. Fig. 15 shows that the microbial oxidation of $\mathrm{Fe}$ (II) follows saturation kinetics in the Fe(II) concentration range studied, and that the rate of 
reaction increases with an increase in bacterial cell density for each Fe(II) concentration used. If the first-order rate constant is calculated by dividing the rate for each Fe(II) concentration in Fig. 15 by the corresponding Fe(II) concentration, then for each cell density, the rate constant will decrease as the Fe(II) concentration is increased between $0.000125-0.003 \mathrm{M}$, as shown by the curves (open symbols) in Fig. 16. Since for every Fe(II) concentration studied, the reaction rate increases as bacterial cell density increases, the curves representing rate constants (rate/corresponding $\mathrm{Fe}(\mathrm{II})$ concentration) versus $\mathrm{Fe}$ (II) concentration are also expected to shift to the right with an increase in bacterial cell density, as shown in Figures 14 and 16.

Furthermore, the curves marked by closed symbols in Fig. 14 and 16 show a decrease in the rate constant as Fe(II) concentration is lowered from the concentration corresponding to the maximum point on those curves. This trend is quite different from that shown by the curves marked by open symbols. However, this difference is expected because of substrate limitations. When a concentration of $\mathrm{Fe}$ (II) lower than that corresponding to the maximum rate constant is used, the reaction occurs very fast initially. To maintain this high initial rate throughout the course of the experiment (e.g., $60 \mathrm{~min})$, the system must have adequate $\mathrm{Fe}$ (II) available for bacterial oxidation. In practice, when a lower $\mathrm{Fe}(\mathrm{II})$ concentration is used, the reaction proceeds so fast initially that the system does not have enough Fe(II) to be oxidized by the bacteria during the later part of the experiment. 
Under this condition, if the duration of the experiment is set at 60 min, then the observed rate constant will be lower than it would be at a shorter duration. This effect will be more pronounced as the concentrations of $\mathrm{Fe}$ (II) continue to decrease. Thus, the rate constant versus Fe(II) concentration curves (Fig. 14 and 16, closed symbols) should show a decrease in rate constant with a decrease in Fe(II) concentration beyond that corresponding to the maximum rate constant.

Previous workers (46-48) have reported that product inhibition due to $\mathrm{Fe}$ (III) occurs simultaneously with the microbial oxidation of $\mathrm{Fe}(\mathrm{II})$. In our study, inhibition by Fe(III) was confirmed by performing additional experiments using a Fe(III) concentration in the range 0.000-0.0005M, while keeping other parameters constant. In these experiments, we observed a decrease in the rate constant with an increase in Fe(III) concentration (Fig. 17a). In agreement with previous reports (46-48), we also observed (by the Dixon method, Fig. 17b) that inhibition of the microbial oxidation of $\mathrm{Fe}$ (II) by $\mathrm{Fe}$ (III) is predominantly competitive.

In order to annul the effect of Fe(III) in our work, an initial kinetic study was performed using an $\mathrm{Fe}$ (II) concentration in the range $0.0005 \mathrm{M}-0.00125 \mathrm{M}$ and the microbial cell density given by $O D_{590}=2.80$, with other conditions unchanged. The plot of the initial rate of Fe(II) oxidation vs Fe(II) concentration is shown in Fig. 18. From this data, we obtained a Lineweaver-Burk plot (Fig. 19) which corresponds to a $K_{m}$ value of $0.00178 \pm 0.00005 \mathrm{M}$. According to previous reports $(48-50), \mathrm{K}_{\mathrm{m}}$ is in the range 0.001 - 
0.01M. Our result is therefore consistent with previous findings. Fig. 19 also suggests that the maximum possible reaction rate, $V_{m}$, is $0.0000165 \pm 0.0000009 \mathrm{~mol} / \mathrm{mg} \mathrm{cells} / \mathrm{min}$.

\section{Effect of Temperature}

Two series of experiments were conducted to demonstrate the variation with temperature of the first-order rate constant of the microbial oxidation of Fe(II). The results of one series of experiments (Table 4) show that the first-order rate constant of the oxidation of $\mathrm{Fe}$ (II) in the presence of $\mathrm{T}$. ferrooxidans increases as the temperature increases from 5.5 to $25^{\circ} \mathrm{C}$, beyond which it decreases to some extent. Thus, $25^{\circ} \mathrm{C}$ is the optimum temperature for the reaction being investigated.

Arrhenius plots generated using the data points from Table 4 (Fig. 20) show that the activation energy of the microbial oxidation of $\mathrm{Fe}$ (II) in the absence of any heavy metal is $11.51 \mathrm{Kcal}$ mole $e^{-1}$ in the temperature range $5.5-25^{\circ} \mathrm{C}$. This value of the activation energy is much lower $(\mathrm{e} . \mathrm{g} .,<5 \mathrm{Kcal} / \mathrm{mol})$ in the range $18-25^{\circ} \mathrm{C}$. The dependence of the activation energy on temperature range has been reported earlier (51) for biotic systems involving T. Eerrooxidans. 
Table 4 Effect of temperature on the rate constant of the bacterial oxidation of ferrous iron.

$\begin{array}{ccc} & \text { Rate constant }\left(\mathrm{min}^{-1}\right) \\ 5.5 & \text { No silver } & 10 \mathrm{ppm} \text { silver } \\ 10 & 0.0120 & 0.0060 \\ 15 & 0.0220 & 0.0100 \\ 21 & 0.0450 & 0.0140 \\ 25 & 0.0500 & 0.0180 \\ 30 & 0.0600 & 0.0285 \\ 35 & 0.0510 & 0.0100 \\ & 0.0500 & 0.0090\end{array}$

\section{Results of Experiments With Heavy Metal Ions}

\section{Effect of Common Heavy Metal Ions}

The effect of a number of heavy metal ions on the rate of Fe(II) oxidation in the presence of $T$. ferrooxidans is shown in Table 5. These data indicate that mercuric ion is the most inhibitory for the reaction being investigated, a finding which agrees with a previous report suggesting that $\mathrm{Hg}$ (II) is toxic to the bacteria (31). Ag(I) was observed to be more inhibitory than any other heavy metal ion studied except $\mathrm{Hg}$ (II). Our results (Table 5) also suggest that the bacteria's normal Fe(II) oxidizing activity is unaffected by the presence of $10 \mathrm{mg} / \mathrm{L} \mathrm{Cu}$ (II), Co(II), or $\mathrm{Zn}(\mathrm{II})$. This observation may indicate that the bacteria has a high tolerance for these cations. Literature reports (31) reveal that the bacteria's Fe(II) oxidizing activity is reduced $7-30 \%$ in the presence of a $\mathrm{Cu}$ (II) concentration in the range 0.1-1M, whereas $0.1 \mathrm{M} \mathrm{Co}(\mathrm{II})$ and $\mathrm{Zn}$ (II) do not have any observable effect on the 
Fe(II) oxidizing activity of $T$. ferrooxidans. While the rate of bacterial oxidation of $\mathrm{Fe}$ (II) is apparently enhanced a little by 10 $\mathrm{mg} / \mathrm{L} \mathrm{Mn}(\mathrm{II}), \mathrm{As}(\mathrm{III})$, or $\mathrm{Sn}(\mathrm{II})$, the Fe(II) oxidizing ability of the bacteria is slightly lowered in the presence of $10 \mathrm{mg} / \mathrm{L} \mathrm{Pb}$ (II) or $\mathrm{Cd}(\mathrm{II})$ in the system. $\mathrm{Pb}(\mathrm{II})$ and $\mathrm{Cd}(\mathrm{II})$ tolerance limits of the bacteria are reported (31) to be around 207 and $112 \mathrm{mg} / \mathrm{L}$, respectively. Thus, the $\mathrm{Cd}(\mathrm{II})$ concentration used in our experiment (i.e., $10 \mathrm{mg} / \mathrm{L}$ ) is not expected to be harmful to the activity of the bacteria. However, our observation of $\mathrm{Pb}$ (II) toxicity contradicts the previous finding (31) mentioned above.

The observed variation in the ferrous iron oxidizing ability of $\mathrm{T}$. ferrooxidans in the presence of different heavy metal ions may be attributed to the variation in the mode of interaction of the ions with the microbial enzymes. However, proper caution must be exercised before suggesting that the presence of $M n$ (II), As (III), and $S n$ (II) in the system is conducive to Fe(II) oxidation by $\mathrm{T}$. ferrooxidans. Our results are based on redox potential measurements, and an increase in redox potential might possibly have occurred due to the oxidation of these three cations. As a result, the redox potential values might have been higher than they would have been if $\mathrm{Fe}$ (II) ions were the only oxidizable cations in the biotic system. Consequently, the value of the rate constant is likely to be overestimated. This was confirmed by the results of additional experiments described below. 
Table 5 Effect of heavy metal ions on the rate of

$\mathrm{Fe}$ (II) oxidation by $\mathrm{T}$. ferrooxidans.

$\begin{array}{lr}\text { Heavy metal ion } & \left.\text { Rate constant (min }{ }^{-1}\right) \\ \text { Ag(I) } & 0.0285 \pm 0.0031 \\ \text { Cu(II) } & 0.0635 \pm 0.0035 \\ \text { Mn (II) } & 0.0635 \pm 0.0035 \\ \text { Hg (II) } & 0.0625 \pm 0.0025 \\ \text { Pb (II) } & 0.0220 \pm 0.0020 \\ \text { As (III) } & 0.0495 \pm 0.0005 \\ \text { Sn (II) } & 0.0630 \pm 0.0030 \\ \text { Cd (II) } & 0.0645 \pm 0.0045 \\ \text { Zn (II) } & 0.0590 \pm 0.0030 \\ \text { Control } & 0.0600 \pm 0.0020\end{array}$

Separate experiments were performed without bacteria, but under standard conditions, and with $10 \mathrm{mg} / \mathrm{L}$ of $\mathrm{Mn}(\mathrm{II}), \mathrm{As}$ (III), and Sn(II). In each of the experiments, the redox potential of the solution was monitored as before using the pyrite indicator electrode for over $60 \mathrm{~min}$. The potential of the indicator electrode remained constant around 375 and $377 \mathrm{mV}$ in experiments involving $10 \mathrm{mg} / \mathrm{L} \mathrm{Mn}$ (II) and As(III), respectively. It may appeax, therefore, that the additional increase in the redox potential values observed during the microbial oxidation of $\mathrm{Fe}$ (II) in the presence of $M n$ (II) and As(III) was due to the enhancement of microbial oxidation of $F \in(I I)$ by these two heavy metal ions. However, the possibility that $M n$ (II) and $A s$ (III) were oxidized either directly by the bacteria or indirectly by the bacteriagenerated Fe(III) cannot be ruled out. According to an earlier report (53), the indirect mechanism is effective in arsenopyrite bioleaching. Thus, the additional increase in the observed values 
of redox potential, which has led to an overestimation of the rate constant of the microbial oxidation of Fe(II) in the presence of $M n(I I)$ and As(III), may be attributed to the oxidation of these heavy metal ions.

On the other hand, the redox potential of the pyrite indicator electrode was observed to increase from an initial value of $155 \mathrm{mV}$ to a final value of $337 \mathrm{mV}$ when $10 \mathrm{mg} / \mathrm{L} \mathrm{Sn}(\mathrm{II})$ was present in the system. This may be due to the oxidation of $\operatorname{sn}$ (II) to $\operatorname{sn}($ IV) by Fe(III). Thus, the oxidation of $S n$ (II) is likely to contribute significantly to an increase in the redox potential during the course of our experiments with the bacteria and Sn(II). Consequently, the observed increase in the rate constant in experiments involving the bacteria and $S n$ (II) may be attributed to the oxidation of $\mathrm{Sn}$ (II) ions.

Further experiments, performed in a similar manner with 10 $\mathrm{mg} / \mathrm{L} \mathrm{Hg}$ (II) and without bacteria, confirmed that the potential of the pyrite indicator electrode was stable around $370 \mathrm{mV}$ for over 90 min. This suggests that $\mathrm{Hg}$ (II) may not undergo any observable redox reaction under the experimental conditions used, a finding that has prompted us to study the effect of $\mathrm{Hg}$ (II) on the Fe(II) oxidizing activity of $\underline{T}$. ferrooxidans using the redox method.

\section{Effect of Silver Ion Concentration}

The effect of the concentration of silver ion on the oxidation of $\mathrm{Fe}$ (II) at $\mathrm{pH} 1.7$ is seen in Fig. 21. The plots of electrode 
potential versus time representing various concentrations of silver ( $1 \mathrm{mg} / \mathrm{L}$ and above) all show values below that corresponding to no silver (or $<1 \mathrm{mg} / \mathrm{L}$ silver). This indicates that silver ions in the range $1-10 \mathrm{mg} / \mathrm{L}$ adversely affect the bacteria's iron oxidizing activity. These results also suggest that a silver concentration of around $0.5 \mathrm{mg} / \mathrm{L}$ does not adversely affect the bacteria's Fe(II) oxidizing activity at $\mathrm{pH}$ 1.7. This may indicate that the bacteria are able to tolerate certain concentrations of silver, a view supported by the results of additional experiments conducted at $\mathrm{pH}$ 1.4 and 3.0 and described below.

Computation of the rate constant and the subsequent plot against silver ion concentration (Fig. 22) show more clearly that the rate of $F e$ (II) oxidation catalyzed by $\mathrm{T}$. ferrooxidans is maintainable up to a threshold value of silver concentration, beyond which the rate decays. According to Fig. 22, the threshold value of silver concentration is $\mathrm{pH}$-dependent. For instance, at $\mathrm{pH}$ 1.7, the maximum concentration of silver that causes no harm to microbial $\mathrm{Fe}$ (II) oxidation is approximately $0.7 \mathrm{mg} / \mathrm{L}$. On the other hand, at $\mathrm{pH}$ 1.4, the maximum value of silver concentration tolerable to the bacterial oxidation of Fe(II) approaches 0.25 $\mathrm{mg} / \mathrm{L}$. At $\mathrm{pH} 3.0$, the effect of silver is not so pronounced, because at this $\mathrm{pH}$ the bacteria's activity is very low even without silver. Thus, our results suggest that the effect of silver on the microbial oxidation of $\mathrm{Fe}$ (II) is dependent on concentration. While a small concentration of silver in the system may be tolerable, an appreciable concentration of silver $10.25 \mathrm{mg} / \mathrm{L}$ or above, depending 
on $\mathrm{pH}$ ) is detrimental to the bacterial oxidation of ferrous iron in solution.

Effect of Fe(II) Concentration in the Presence of Silver

From the rate constant versus Fe(II) concentration plots in Fig. 14 (open symbols), it can be seen that the curves representing microbial Fe(II) oxidation in the presence of silver shift towards the left as the cell density of the bacteria is decreased from $O D_{590}=5.85$ to 1.41 . This shift can be explained by the fact that silver ions may deactivate a portion of the microbial enzymes, reducing the proportion of the cells effective for Fe(II) oxidation when $10 \mathrm{mg} / \mathrm{L} \mathrm{Ag}^{+}$is present in the system. However, since the silver concentration is fixed, it may deactivate a fixed number of cells from each of the three microbial cell concentrations studied. Consequently, the effective number of cells in our work should follow the sequence

$$
O D_{590}=1.41<O D_{590}=2.80<\mathrm{OD}_{590}=5.85
$$

A reduction in the number of effective cells would suggest that the reaction rate will reach the saturation level at a lower Fe(II) concentration, as shown in Fig 15. Similarly, if the effective cell density is increased, then the rate of reaction will attain the saturation value at a higher Fe(II) concentration. It is for this reason that the rate constant versus $F e$ (II) concentration curves (Fig. 14, open symbols) should shift towards 
the left as the cell density of the bacteria is decreased.

The effect of $\mathrm{Fe}(\mathrm{II})$ concentration on bacterial activity in the presence of silver is also indicated by the results of the initial kinetic study (Fig. 18). The initial rate of oxidation of ferrous iron is reduced significantly by the presence of $10 \mathrm{mg} / \mathrm{L}$ silver in the biotic system. Lineweaver-Burk analysis of the data represented by Fig. 18, corresponding to the lines with open symbols in Fig. 19, shows that the average value of $\mathrm{K}_{\mathrm{m}}$ increases to $0.00237 \pm 0.00026 \mathrm{M}$, whereas the $\mathrm{V}_{\mathrm{m}}$ value is reduced to $0.0000121 \pm$ $0.0000029 \mathrm{~mol} / \mathrm{mg}$ cells $/ \mathrm{min}$ due to the presence of $10 \mathrm{mg} / \mathrm{L} \mathrm{Ag}^{+}$in our system.

\section{Effect of Temperature in the Presence of Silver}

If the $\mathrm{T}$. ferrooxidans cells are exposed to $10 \mathrm{mg} / \mathrm{L}$ silver and the reaction temperature is concurrently varied from the optimum value of $25^{\circ} \mathrm{C}$, then the rate of microbial oxidation of ferrous iron may decrease remarkably, as shown in Table 4. For instance, at $25^{\circ} \mathrm{C}$ and in the presence of $10 \mathrm{mg} / \mathrm{L}$ silver, the observed rate constant of the reaction is $0.0285 \mathrm{~min}^{-1}$. In the presence of $10 \mathrm{ppm}$ silver, if the reaction temperature is varied from $25^{\circ} \mathrm{C}$ to 5.5 and $35^{\circ} \mathrm{C}$, the rate constant is observed to be lowered to 0.006 and $0.009 \mathrm{~min}^{-1}$, respectively.

Arrhenius plots (Fig. 20) based on the data in Table 4 yield an activation energy of $12.33 \mathrm{Kcal}$ mole-1 for experiments with 10 ppm silver. 


\section{oxidation of Fe(II) with Bacteria Conditioned with Silver}

\section{Effect of Time}

These experiments were performed to examine the effect of conditioning the bacteria with silver for varying amounts of time. The effect of the conditioning period of $\mathrm{T}$. ferrooxidans with 10 mg/L silver on the observed electrode potential is shown in Fig. 23. The curves corresponding to different periods of initial contact of $\underline{T}$. ferrooxidans with silver are well below those representing no conditioning of the bacteria. This observation suggests that a pre-contact with soluble silver remarkably reduces the bacteria's iron oxidizing activity. This effect becomes more pronounced as the duration of conditioning is increased from 0 to 2 hours (Fig. 23). An explanation for this observation is that as the duration of pre-conditioning increases, an increasing number of $\mathrm{Ag}^{+}$ions may diffuse into the periplasmic space to occupy the active sites on the microbial enzyme, leading to deactivation of the enzyme (s).

Figure 24 shows that the rate constant of Fe(II) oxidation decreases as the duration of the conditioning period of bacteria with $10 \mathrm{mg} / \mathrm{L}$ silver is increased. The effect of conditioning time also depends on the concentration of silver. For example, after 30 minutes' conditioning with $1,2.5$, and $10 \mathrm{mg} / \mathrm{L}$ silver, the activity of the bacteria expressed as the rate constant of Fe(II) oxidation was $0.0485,0.0415$, and $0.017 \mathrm{~min}^{-1}$, respectively (Fig. 24). 


\section{Effect of $\mathrm{pH}$}

Fig. 25 compares the effect of $\mathrm{pH}$ on the rate constant of the microbial oxidation of $\mathrm{Fe}$ (II) in the absence and the presence of $\mathrm{Ag}^{+}$. The top curve represents the Fe(II) oxidizing activity of the bacteria in test solutions of different $\mathrm{pH}$ in the absence of silrer. The middle curve corresponds to the Fe(II) oxidizing activity of the bacteria in the presence of $10 \mathrm{mg} / \mathrm{L}$ silver in solutions of various $\mathrm{pH}$, while the bottom curve demonstrates the activity of the bacteria conditioned for 1 hour with $10 \mathrm{mg} / \mathrm{L} \mathrm{Ag}^{*}$. under similar conditions. A comparison of the top curve with the other two curves suggests that the presence of $10 \mathrm{mg} / \mathrm{L} \mathrm{Ag}^{+}$in the system is adverse to bacterial activity. Conditioning the bacteria with $10 \mathrm{mg} / \mathrm{L}$ silver for 1 hour is even more detrimental to the microbial oxidation of $\mathrm{Fe}(\mathrm{II})$. For example, at $\mathrm{pH} 1.7$ and in the absence of silver, the rate constant of bacterial oxidation of ferrous iron is $0.06 \mathrm{~min}^{-1}$. In the presence of $10 \mathrm{mg} / \mathrm{L}$ silver (without conditioning), this value is reduced to $0.0285 \mathrm{~min}^{-1}$. When the bacteria are conditioned with $10 \mathrm{mg} / \mathrm{L}$ silver for a period of 1 hour, the rate of bacterial oxidation of Fe(II) is further lowered to $0.012 \mathrm{~min}^{-1}$.

Fig. 25 also shows that a change of $\mathrm{pH}$ beyond $1.5-2.0$ has a negative effect on the activity of the bacteria in the absence of silver ions. However, because of severe loss in microbial activity due to the presence of silver ions and conditioning with silver, the $\mathrm{pH}$ effect becomes less pronounced in all experiments with silver ions. Consequently, the portion of the rate constant versus 
$\mathrm{pH}$ curve in the vicinity of the peak (Fig. 25, top curve) spreads over a wider $\mathrm{pH}$ range, with an attendant decrease in the activity of the bacteria, if $10 \mathrm{mg} / \mathrm{L}$ silver is present in the system. It becomes even wider and shows further loss of bacterial activity when the bacteria are conditioned with $10 \mathrm{mg} / \mathrm{L}$ silver for 1 hour. Thus, according to Fig. 25, factors adversely affecting the activity of the $\mathrm{T}$. ferrooxidans may be arranged in the following sequence:

Conditioning with $\mathrm{Ag}^{+}>$Presence of $\mathrm{Ag}^{+}>\mathrm{pH}$ changes above 1.7-2.0.

\section{Mechanism of Inhibition by Silvex Ions}

Lineweaver-Burk analysis has been used in our work to uncover the mechanism of inhibition of microbial Fe(II) oxidation in the presence of silver ions. This method is generally applicable to elucidating the inhibition mechanism of the enzyme-catalyzed reactions (55). Following this method (54), two parallel series of experiments were performed using different concentrations of the substrate, e.g, Fe(II), and keeping other experimental parameters ( $\mathrm{pH}$, temperature, bacterial cell density, etc.) constant. In one series of experiments, a constant $\mathrm{Ag}^{+}$concentration $(10 \mathrm{mg} / \mathrm{L}$ ) was used, while Fe(III) was not used in either series. The reciprocal of the observed initial rate was the plotted as a function of the reciprocal of the initial Fe(II) concentration to obtain two straight lines, as shown in Fig. 19. The double reciprocal plots are explainable in terms of the Michaelis-Menten equation (equation 
4) for mixed inhibition (54):

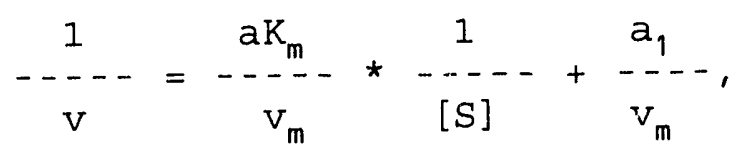

where $\mathrm{v}=$ rate of reaction, $[\mathrm{S}]=\mathrm{Fe}(\mathrm{II})$ concentration, $\mathrm{v}_{\mathrm{m}}=$ maximum reaction rate possible, $\mathrm{K}_{\mathrm{m}}=\mathrm{Fe}$ (II) concentration at half the maximal rate of reaction, and $a$ and $a_{1}$ are constants which equal 1 in the absence of an inhibitor. Equation 2 shows that if $1 / v$ is plotted against $1 /[S]$ for various concentrations of silver $\left(\left[\mathrm{Ag}^{+}\right]=0\right.$ for the uninhibited case), this equation would describe a family of lines intersecting at the left of $1 / v$ axis, as shown in Fig. 19. The presence of a mixed inhibitor causes the Y-intercept to increase and the $\mathrm{X}$-intercept to decreases relative to the uninhibited case (54). A mixed inhibitor (I) in enzyme kinetics reportedly (54) combines with both the enzyme (E) and the enzymesubstrate complex (ES) according to the following scheme:

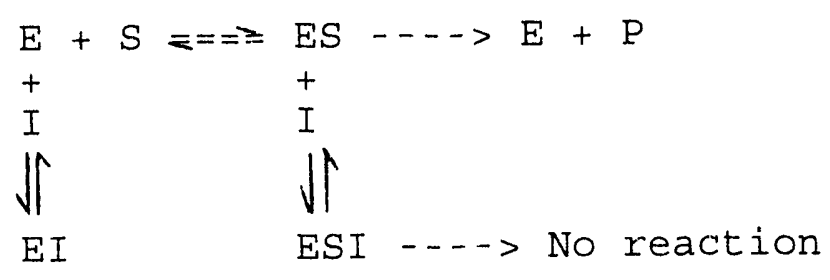

A comparison of the straight lines symbolized by squares and triangles in Fig. 19 shows that due to inhibition by $\mathrm{Ag}^{+}$, the $\mathrm{X}-$ intercept has decreased, resulting in an increase in $\mathrm{K}_{\mathrm{m}}$ value from $0.00178 \mathrm{M}$ (uninhibited case) to $0.00237 \mathrm{M}$ (inhibited case), whereas 
the $\mathrm{Y}$-intercept has increased, leading to a decrease in $\mathrm{v}_{\mathrm{m}}$ from $0.0000165 \mathrm{~mol} / \mathrm{mg}$ cells $/ \mathrm{min}$ (uninhibited case) to $0.0000121 \mathrm{~mol} / \mathrm{mg}$ cells/min. Enzyme kinetics (54) suggest that the inhibition of microbial oxidation of $\mathrm{Fe}(\mathrm{II})$ in the presence of $\mathrm{Ag}^{+}$takes place via the mechanism cited above. Since $\mathrm{Ag}^{+}$may block the active site on the enzyme as well as combine with the enzyme-Fe(II) complex, it is likely that in the presence of $\mathrm{Ag}^{+}, \mathrm{Fe}$ (II) oxidation may not be fast enough to be controlled by the diffusion coefficient of $\mathrm{Fe}$ (II) through the cell wall. On the contrary, it should be proportional to the concentration of the enzyme-Fe(II) complex (i.e., $C_{\text {Enzyme- }}$ Fe(II)), which has been able to avoid combination with $\mathrm{Ag}^{+}$. This concentration, in turn, is likely to be controlled by the rate constants of the kinetic steps in the above-mentioned reaction scheme. An increase in $\mathrm{K}_{\mathrm{m}}$ due to inhibition by silver ions suggests that the rate constant of the formation of the enzymesubstrate complex might have been reduced by silver ions, making it the slowest of all the rate constants (except the dissociation constants of EI and ESI) in the above scheme. Thus, the overall rate of $F e(I I)$ oxidation in the presence of silver may be kinetically controlled. The observed activation energy value of $12.33 \mathrm{Kcal} \mathrm{mol}^{-1}$ in the presence of $10 \mathrm{mg} / \mathrm{L} \mathrm{Ag}^{+}$indicates $\mathrm{kinetic}$ control of the reaction being investigated.

The proposed mechanism involves a direct contact between the microbial cells and silver ions. Evidence in support of direct interaction between the microbes and $\mathrm{Ag}^{+}$comes from experiments designed to follow the bulk concentration of silver (e.g., using 
atomic absorption ( $A A$ ) spectroscopy) and by microscopic examination of cells treated with silver. In our AA work, an experiment was performed with $\mathrm{T}$. ferrooxidans cells, $2.5 \mathrm{mg} / \mathrm{L} \mathrm{Ag}^{+}$, and other standard conditions. Two samples were withdrawn, one at the beginning (i.e., head) and the other when the experiment was over (i.e., tail). The bacteria were separated from the samples by filtration through Millipore filters (pore size $0.25 \mu \mathrm{m}$ ) and the filtrate analyzed for silver with flame AA at $328.1 \mathrm{~nm}$. Typical results (Table 6 ) showed a slight decline in the bulk concentration of silver attributable to accumulation of $\mathrm{Ag}^{+}$by $\mathrm{T}$. ferrooxidans cells. Indeed, silver accumulation onto bacteria has been confirmed by electron microscopic examination (using SEM and TEM) of cells treated with silver, as discussed below.

Table 6 Results of AA analysis of samples taken from experiments to diagnose the fate of silver

$\begin{array}{lccc}\text { Sample } & \text { Time } & \text { Absorbance } & \text { Ag concentr- } \\ \text { due to Ag } & \text { ation (mg/L) } \\ \text { Head } & 0 & 0.257 & 2.7 \\ \text { Tail } & 90 & 0.237 & 2.4\end{array}$

For electron microscopy studies, experiments were performed in a similar manner and samples were taken from ongoing experiments with $2.5 \mathrm{mg} / \mathrm{L}$ silver and without silver (control). The bacteria were filtered onto Millipore filters as specified above, washed three times with $\mathrm{pH} 1.7$ deionized water, and then examined by SEM. The SEM micrographs (Fig. 26) of samples with and without silver 
are similar; however, EDAX analysis reveals the presence of a little silver on $\underline{T}$. ferrooxidans cells withdrawn from the experiment with $2.5 \mathrm{mg} / \mathrm{L}$ silver (Fig. 26a). As expected, no silver was detectable on the bacteria taken from the control experiment (Fig. 26b), suggesting that silver ions bind to the microbial cells.

Further studies using TEM on samples prepared in a similar manner have identified spots on the cells which correspond to the accumulation of both metallic and nonmetallic species. For example, micrographs of bacteria taken from control experiments (Fig. 27a) contain lighter spots corresponding to the presence of Fe, $\mathrm{Ca}, \mathrm{K}, \mathrm{Si}, \mathrm{P}$, and $\mathrm{S}$ (Fig. 28a). The $\mathrm{Cu}$ and $\mathrm{Si}$ observed in this figure came from the $\mathrm{Cu}$ support grid and Si grease used in the TEM work. The other cations and $\mathrm{P}$ might have come from the nutrient medium salt solution used during fermentation of the bacteria. S is likely to be from $\mathrm{SO}_{4}{ }^{2-}$. Photomicrographs of the bacteria taken from an experiment with $2.5 \mathrm{mg} / \mathrm{I}$ silver ions contain both lighter and darker spots (Figs. 27b and 27c). EDAX analysis reveals that the darker spots are due to the accumulation of Ag onto the cell (Fig. 28b). Thus, our SEM and TEM work confirm that there is a direct interaction between silver ions and I. Eerrooxidans cells, as required by the proposed mechanism of inhibition of bacterial activity by $\mathrm{Ag}^{+}$ions.

Although our observation of silver deposition onto the cells agrees well with the previous reports of accumulation of silver onto $\mathrm{T}$. ferrooxidans cells during leaching of sulfide minerals (55, 
56), this study is not able to specify the actual site on the microbial cell at which silver accumulates. However, on the basis of these results and our earlier observations, we may make an educated guess as to the identity of the silver-binding sites on the bacterial cell. Previously $(56,57)$, silver was seen to be complexed by the -SH group of amino acids such as cysteine. In accordance with a recent report (58), $\mathrm{Ag}^{+}$is often separated from waste water with ion-exchangers containing - SH as the terminal group. These observations (56-58) and other reports $(41,43,44)$ indicate that silver has a great affinity for sulfur. Since $\underline{T}$. ferrooxidans cells are known (49) to possess sulfur-containing proteins (e.g., cysteine), the thiol (-sH) terminal groups of those proteins may act as potential sites for binding $\mathrm{Ag}^{+}$ions.

\section{Mechanism of Inhibition of Fe(II) oxidation by $\mathrm{T}$. ferrooxidans is the Presence of $\mathrm{Hg}$ (II)}

The effect of mercury on the microbial oxidation of ferrous iron was studied exactly as described above for silver. The results are also similar, except for the effects of $\mathrm{Fe}$ (II) concentration and temperature in the presence of $\mathrm{Hg}$ (II). For this reason, only these two significant effects will be mentioned here.

Lineweaver-Burk analysis has been used, as before, to uncover the mechanism of inhibition of $\mathrm{Fe}$ (II) oxidation by $\mathrm{Hg}$ (II). Initial rates of Fe(II) oxidation by the bacteria in the absence and presence of $10 \mathrm{mg} / \mathrm{L} \mathrm{Hg}$ (II) were obtained according to the method cited above. The reciprocal of the initial rate was then plotted 
against the reciprocal of initial Fe(II) concentration to obtain Fig. 29. The double reciprocal plots in Fig. 29 are explainable in terms of the Michaelis-Menten equation (equation 6) for uncompetitive inbibition (54)

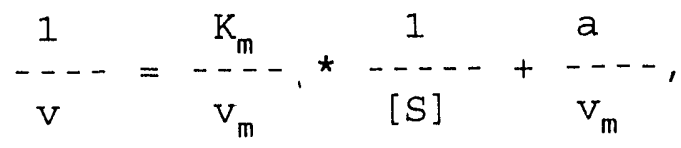

where the terms have the same meaning as before (equation 4). Since $K_{m}$ and $V_{m}$ values are the same as in the uninhibited case, a plot of $1 / v$ as a function of $1 /[S]$ will generate a straight line parallel to the uninhibited line. Thus, both the $\mathrm{X}$ - and the $\mathrm{Y}$ intercept are expected to increase due to uncompetitive inhibition, which is represented by the following scheme (54):

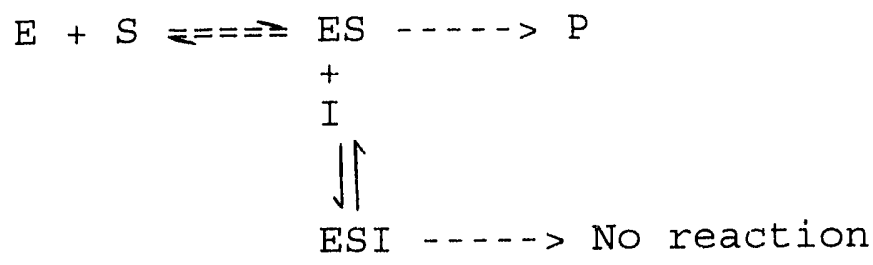

As seen in Fig. 29, because of inhibition by $10 \mathrm{mg} / \mathrm{L} \mathrm{Hg}$ (II), both of the intercepts have increased in magnitude in comparison to the uninhibited intercepts. It is therefore likely that $\mathrm{Hg}$ (II) ions may inhibit the oxidation of $\mathrm{Fe}$ (II) by $\mathrm{T}$. ferrooxidans according to the uncompetitive mechanism cited above. Evidence in support of direct interaction between the bacteria and the Hg(II) ions have been provided by additional experiments with $A A$ and 
electron microscopy. The procedure followed was exactly the same as described for silver.

Our AA results showed a slight decline (approximately 0.3 $\mathrm{mg} / \mathrm{L}$ ) in the bulk concentration of mercury, attributed to accumulation of $\mathrm{Hg}$ by the bacteria. Indeed, $\mathrm{Hg}$ was detected on $\mathrm{T}$. ferrooxidans by electron microscopic studies (SEM, TEM and EDAX). Since the photographs and $x$-ray emission spectra are similar to those shown above for silver, they are not shown here.

Our proposed mechanism suggests that mercury may bind with the enzyme-Fe(II) complex. This suggestion agrees well with the previous suggestion by Imai et al. (3I) that $\mathrm{Hg}$ (II) may inhibit cytocrome oxidase $a$, which is a very important component of the iron oxidizing system of $T$. ferrooxidans.

According to the above mechanism, the rate of Fe(III) production will be proportional to the concentration of the enzymeFe(II) complex that has been able to avoid combination with Hg (II). A consideration of the equilibria involved in the above mechanism suggests that this concentration of enzyme-substrate complex (ES) would be controlled by the rate of its formation. This suggestion is based on the fact that ES is consumed by the processes of formation of Fe(III) and ESI and decomposition to Eree enzyme. Consequently, to maintain a concentration of ES in the system, it has to be formed at a rate comparable with the rate at which it is being consumed. Since Hg(II) may not bind with the free enzyme, it is likely that the rate of generation of ES will depend on the rate of diffusion of $\mathrm{Fe}$ (II) into the periplasmic space of the bacteria. 
Thus, microbial oxidation of $\mathrm{Fe}$ (II) in the presence of $\mathrm{Hg}$ (II) should be diffusion-controlled. The observed activation energy value of approximately $5 \mathrm{Kcal} \mathrm{mol}^{-1}$ (Fig. 30) in both the presence and the absence of $10 \mathrm{mg} / \mathrm{L} \mathrm{Hg}$ (II) suggests that the reaction is controlled by the diffusion of $\mathrm{Fe}(\mathrm{II})$ ions.

\section{Effect of Anions}

Two separate experiments were performed with $10 \mathrm{mg} / \mathrm{L} \mathrm{Cl}^{-}$and $\mathrm{NO}_{3}{ }^{-}$and other standard conditions, to evaluate the effect of these anions on the Fe(II) oxidizing ability of T.ferrooxidans. The rate constant in each case was observed to be $0.06 \mathrm{~min}^{-1}$, which is the standard value of our rate constant. Thus, the presence of $10 \mathrm{mg} / \mathrm{L}$ of $\mathrm{Cl}^{-}$and $\mathrm{NO}_{3}^{-}$in our biotic system does not have an observable effect on the Fe(II) oxidizing activity of the bacteria. 


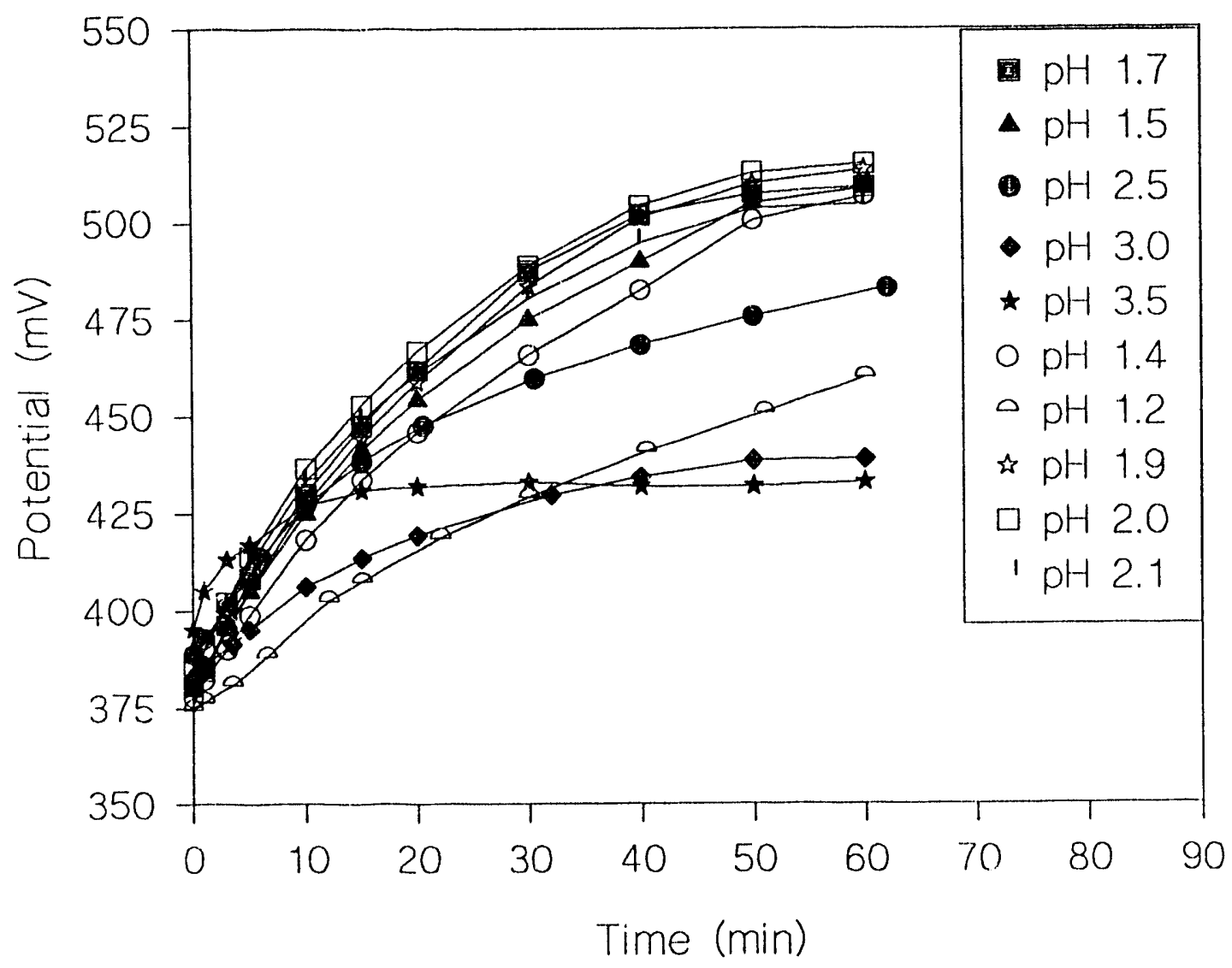

Fig. 12 Effect of $\mathrm{pH}$ on the redox potential of pyrite electrode during bacterial oxidation of $\mathrm{Fe}(\|)$. 


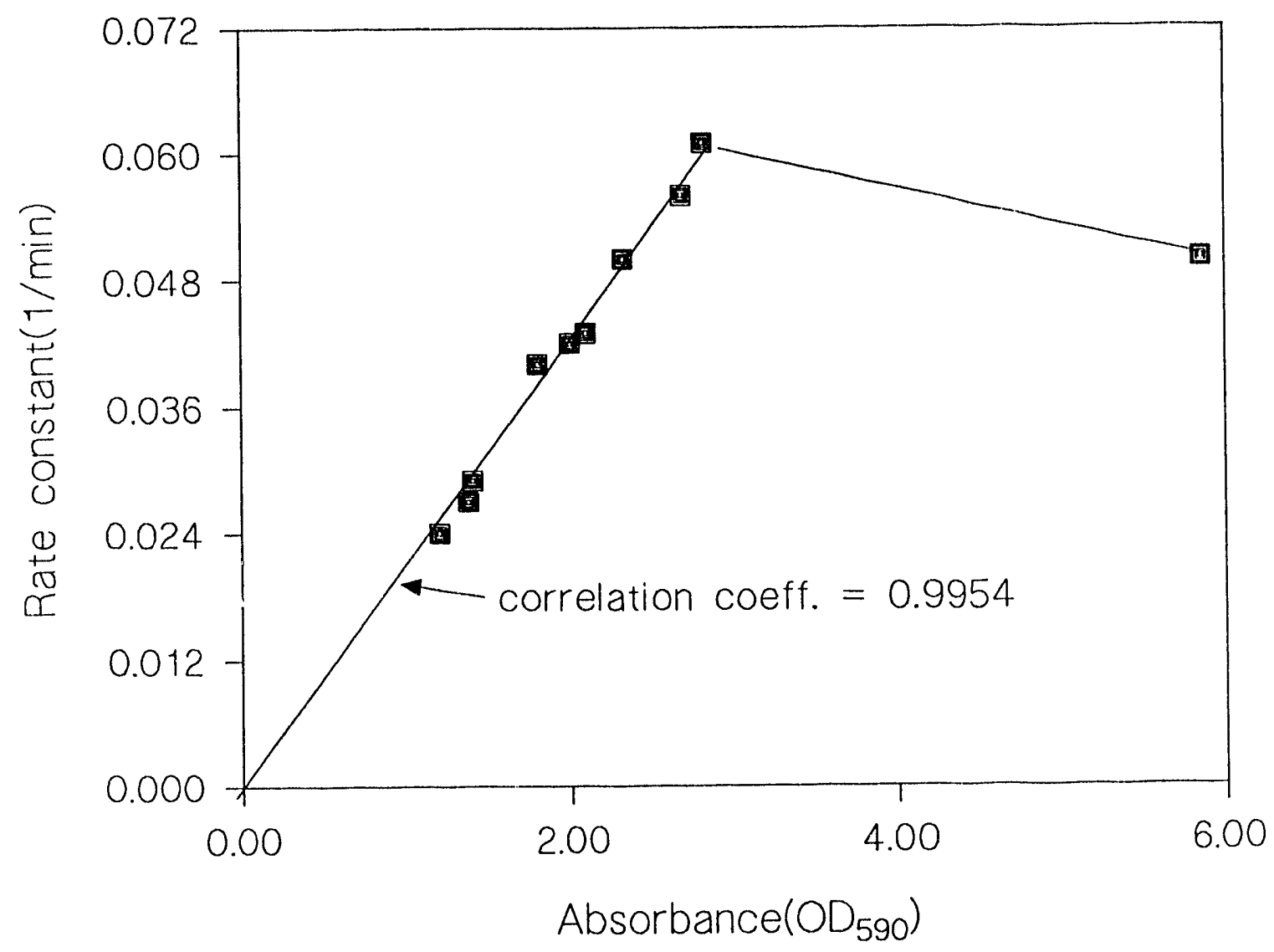

Fig. 13 Rate constant of microbial oxidation of Fe(ll) as a function of cell density in terms of $\mathrm{OD}_{590}$. 


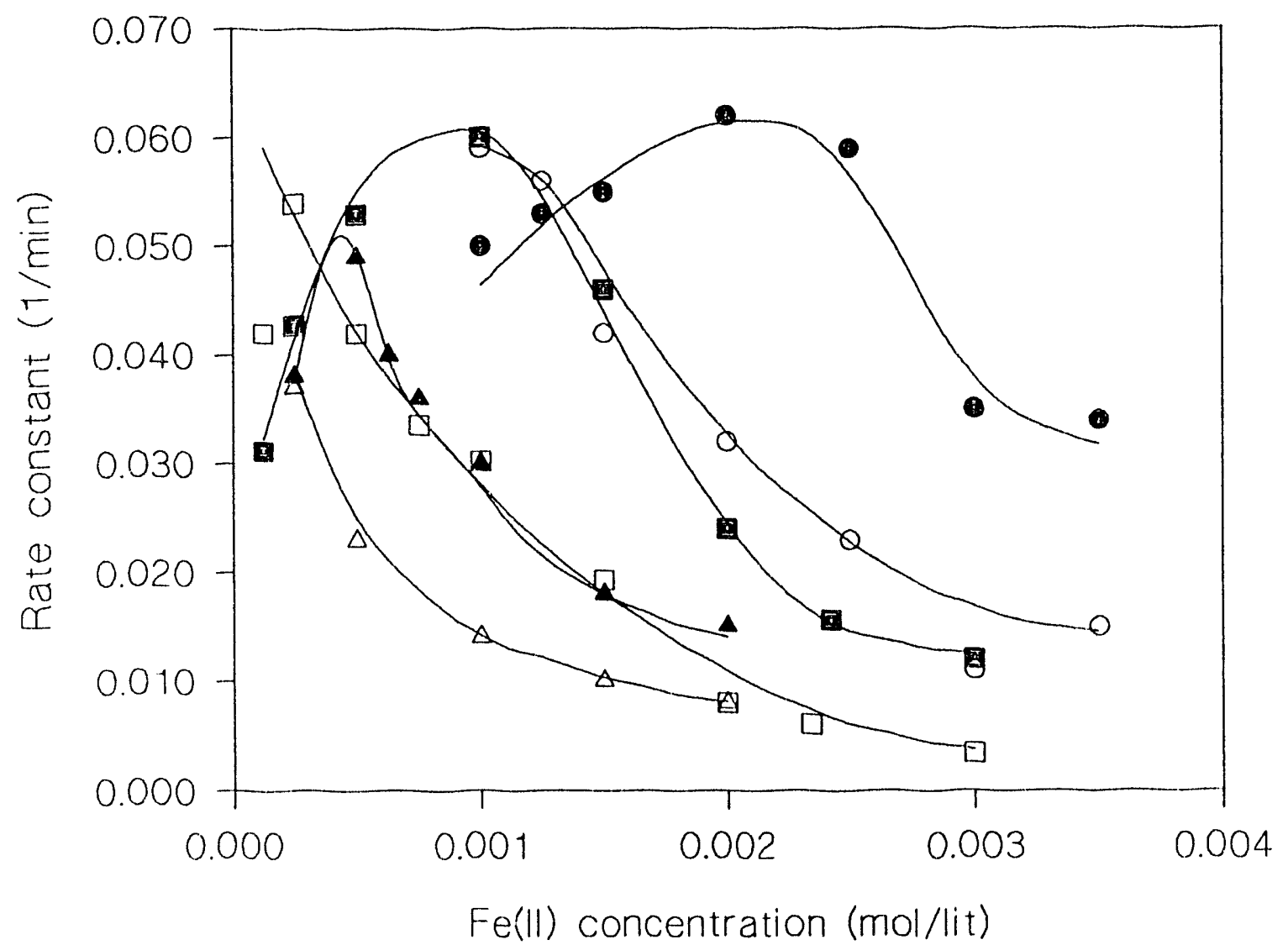

Fig. 14 Rate constant of microbial oxidation of $\mathrm{Fe}(\mathrm{Il})$ as a function of $\mathrm{Fe}(\mathrm{ll})$ concentration, at $\mathrm{pH}$ 1.7. (Circles $\mathrm{OD}_{590}$ 5.85; Squares: $O_{590}$ 2.8; Triangles: $O_{590}$ 1.41). Closed symbols were experiments without silver; Open symbols experiments with $10 \mathrm{mg} / \mathrm{L}$. silver. 


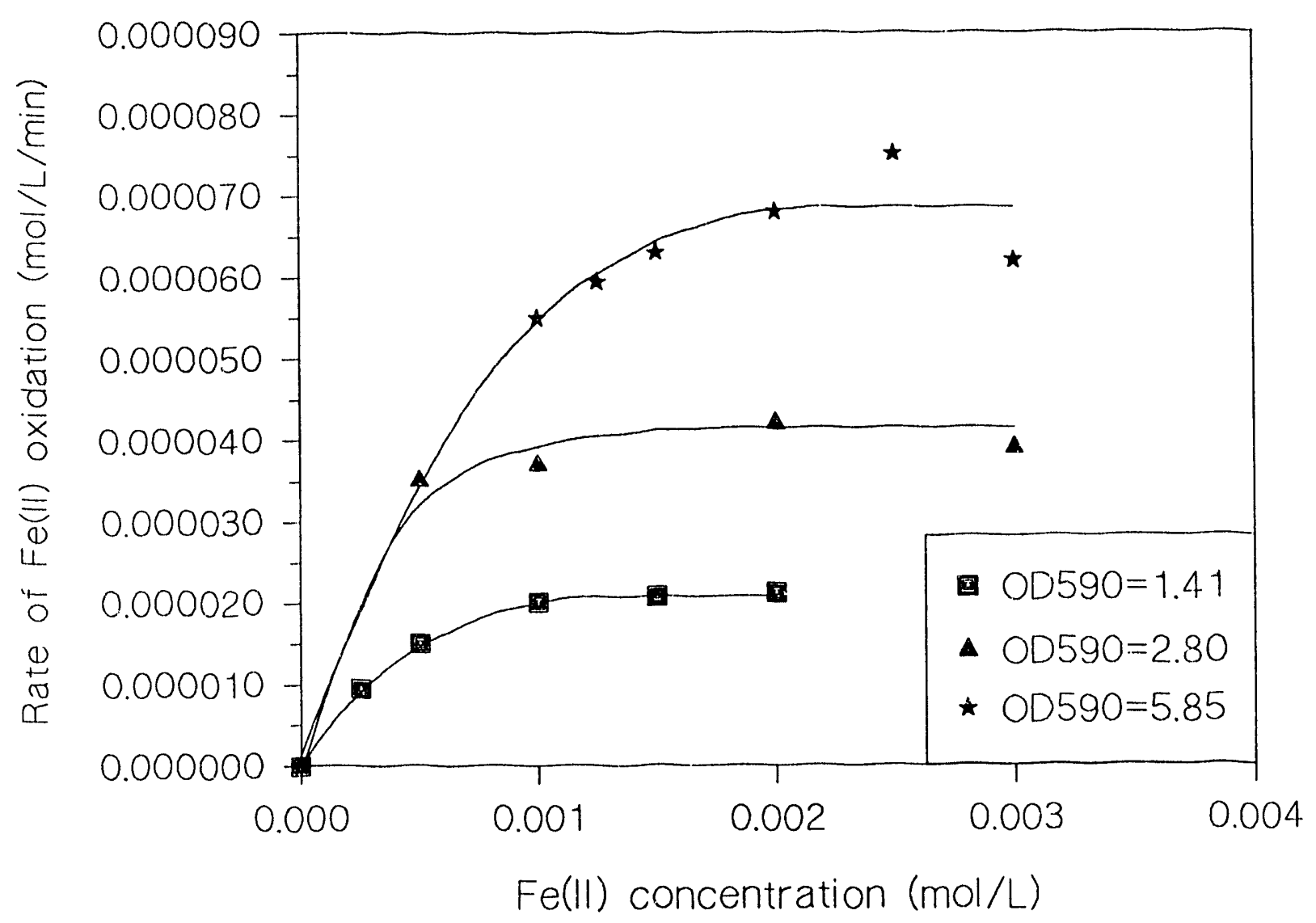

Fig. 15 Initial rate of microbial oxidation of Fe(ll) as a function of initial concentration of $\mathrm{Fe}(\mathrm{II})$ in the absence of heavy metal ions. Three different cell densities were used. 


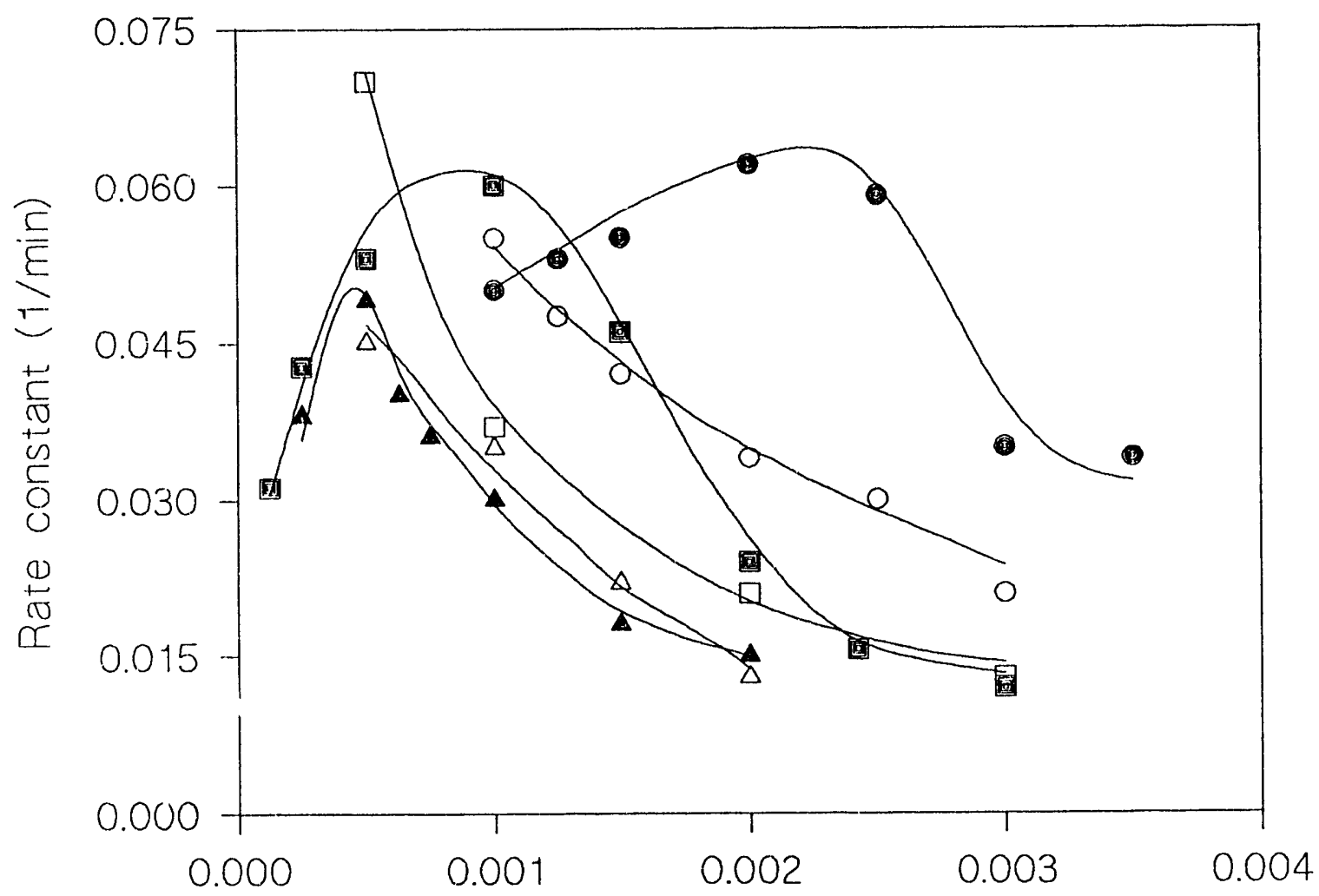

Fe(II) concentration (mol/lit)

Fig. 16 Rate constants of microbial oxidation of $\mathrm{Fe}(\|)$ as a function of $\mathrm{Fe}(\mathrm{II})$ concentration at $\mathrm{pH}$ 1.7. Rate constants evaluated up to $15 \mathrm{~min}$ (open symbols) $z_{1} \mathrm{nd} 60 \mathrm{~min}$ (closed symbols) of reaction time. (Squares: $O D_{590} 2.8$; Triangles: ${ }\left[_{590}\right.$ 1.41). 


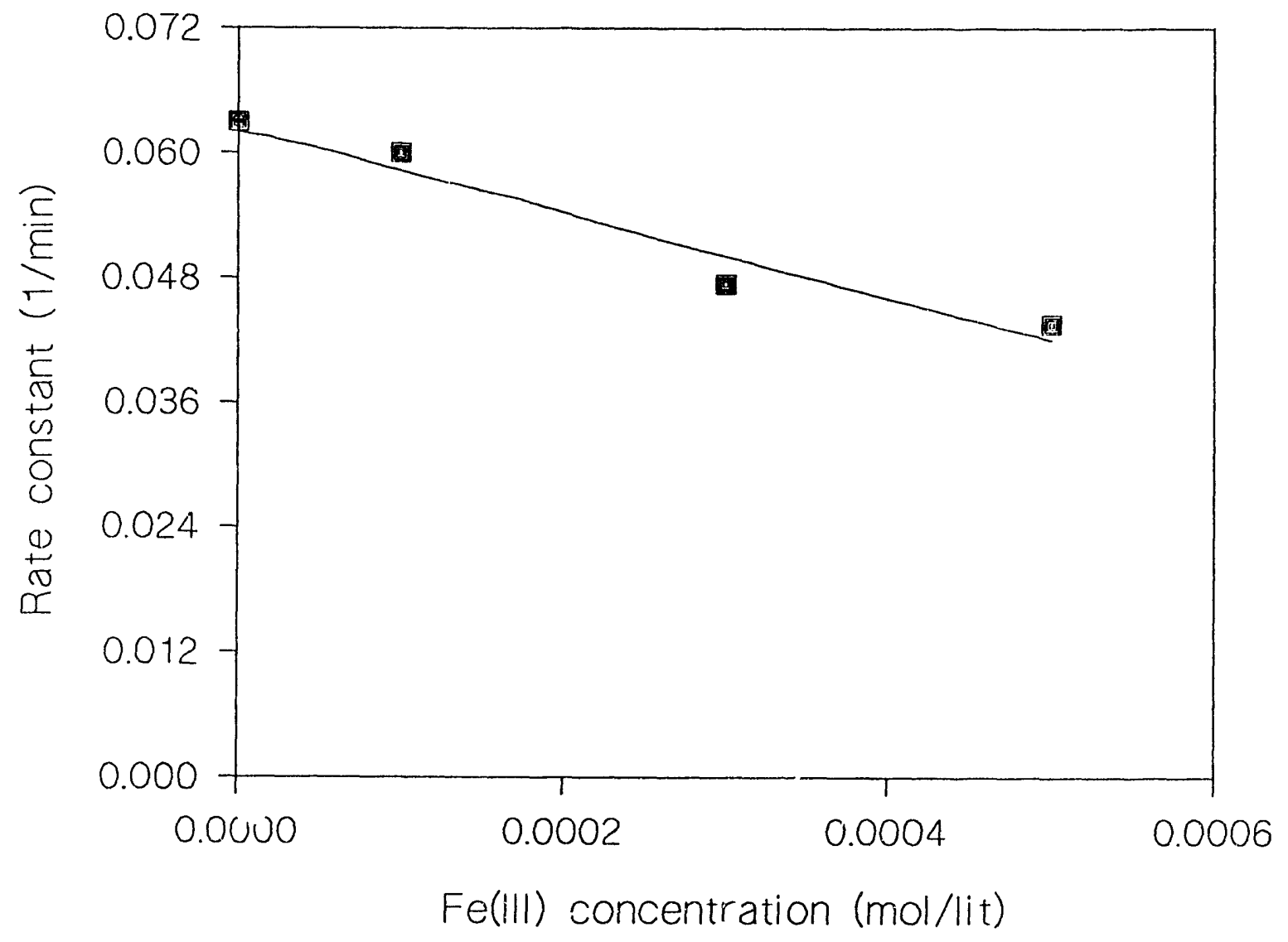

Fig. 17a Effeci of initial Fe(III) concentration on the rate of microdial oxidation of $\mathrm{Fe}(\mathrm{II})$. 


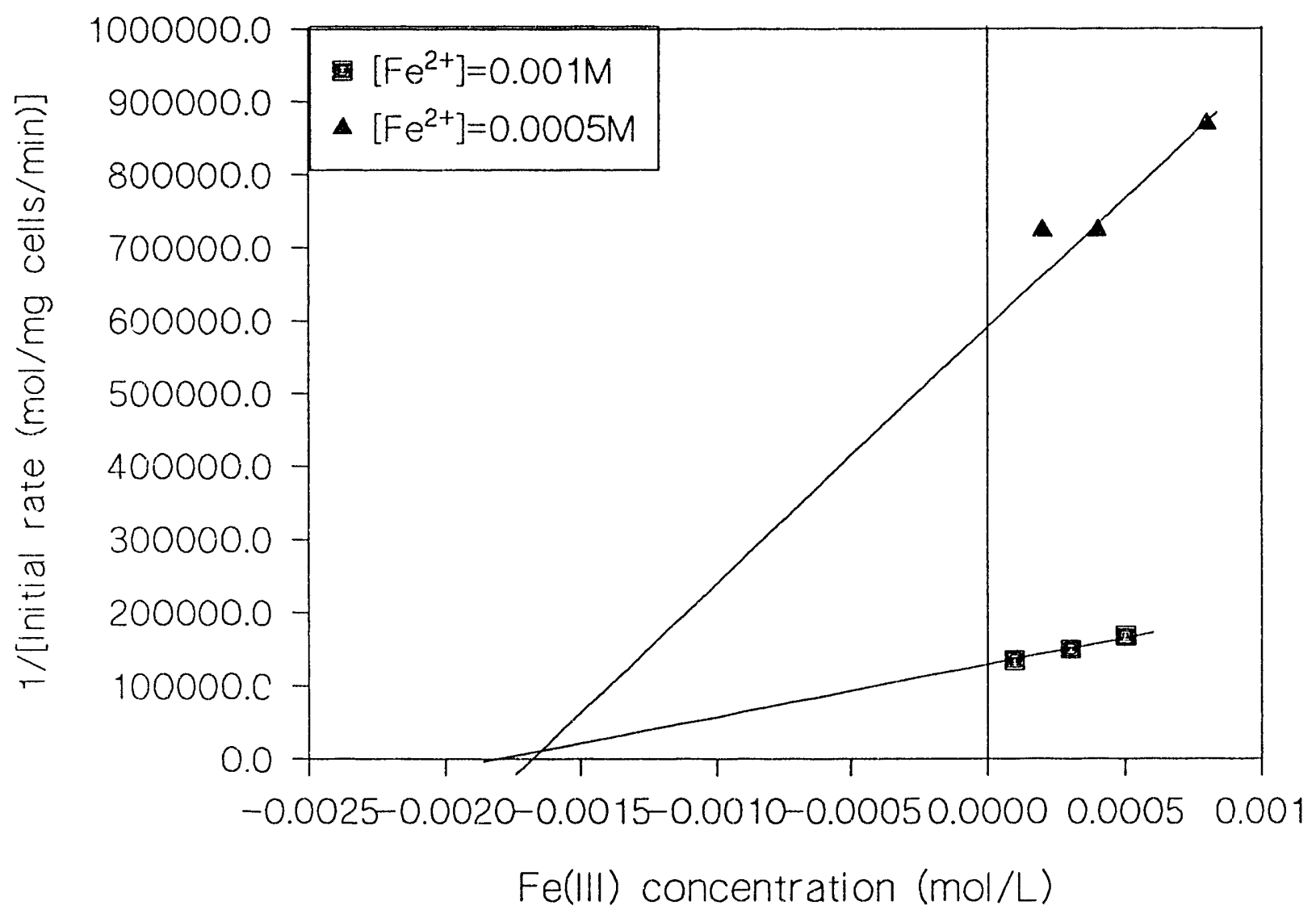

Fig. 17b Dixor's method of analysis of competitive inhibition of Fe(III). 


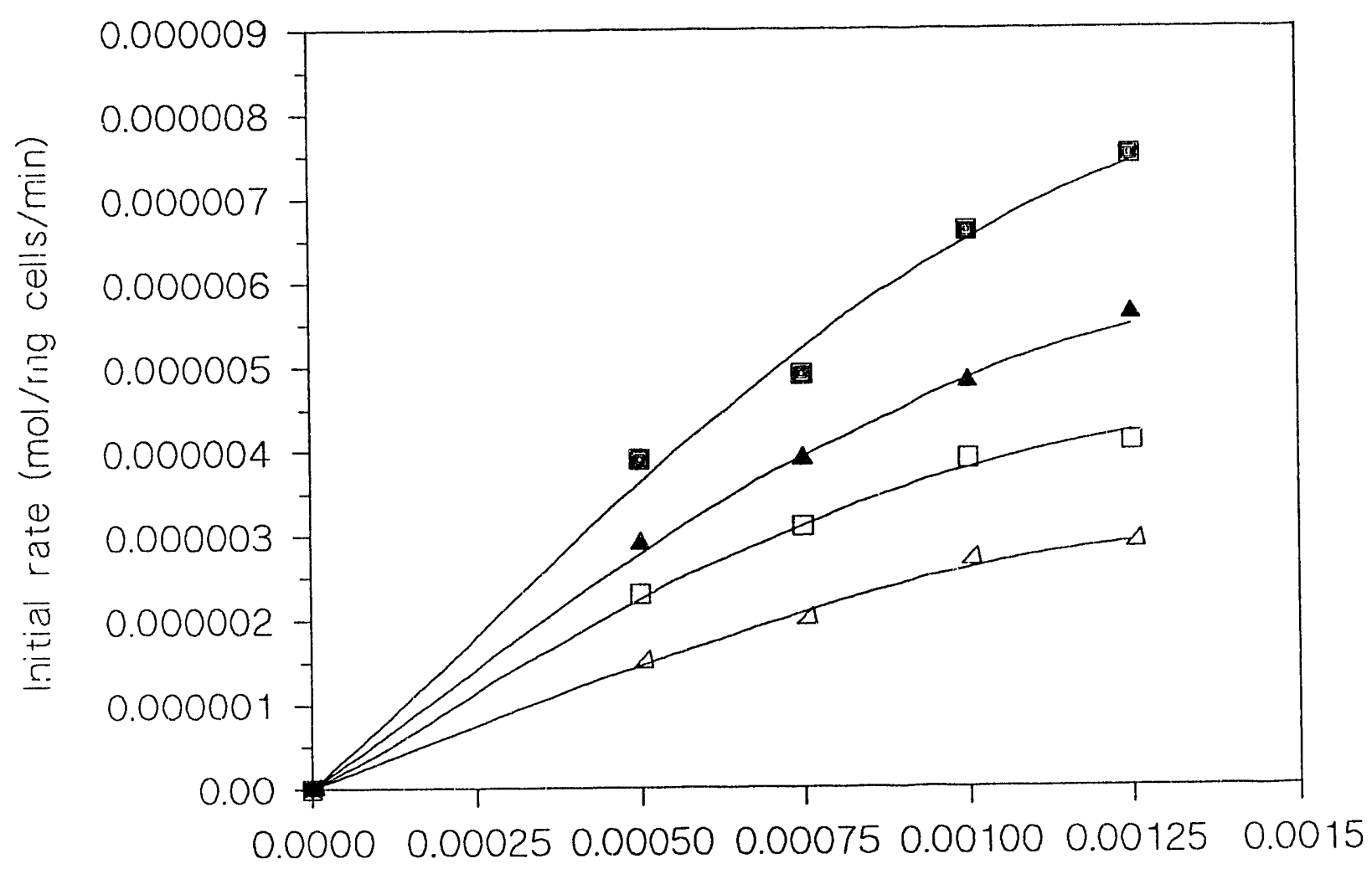

Fe(II) concentration ( $\mathrm{mol} / \mathrm{L}$ )

Fig. 18 Initial rate of microbial oxidation of Fe(II) as function of initial $F \in(I I)$ concentration in the absence and in the presence of silver. (Squares: No silver present; Triangles: $10 \mathrm{mg} / \mathrm{L}$. Open symbols: 4-day old bacterial batch; Closed symbols: 5-day old bacterial batch). 


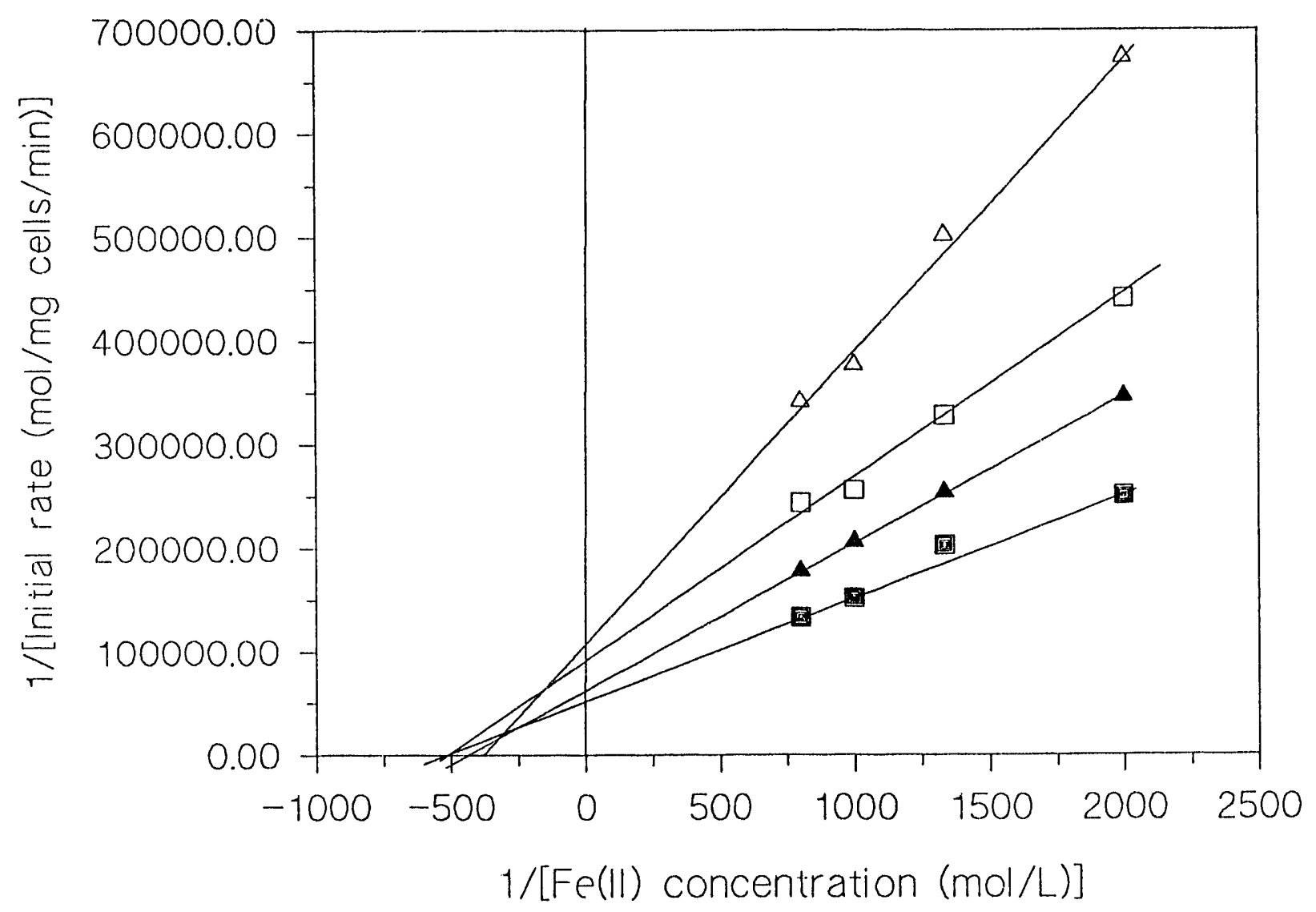

Fig. 19 Lineweaver-Burk plot for the microbial oxidation of Fe(II) in the absence (squares) and in the presence of $10 \mathrm{mg} / \mathrm{L}$ silver (triangles). (Open symbols: 4-day old bacterial batch; Closed symbols: 5-day old batch.) 


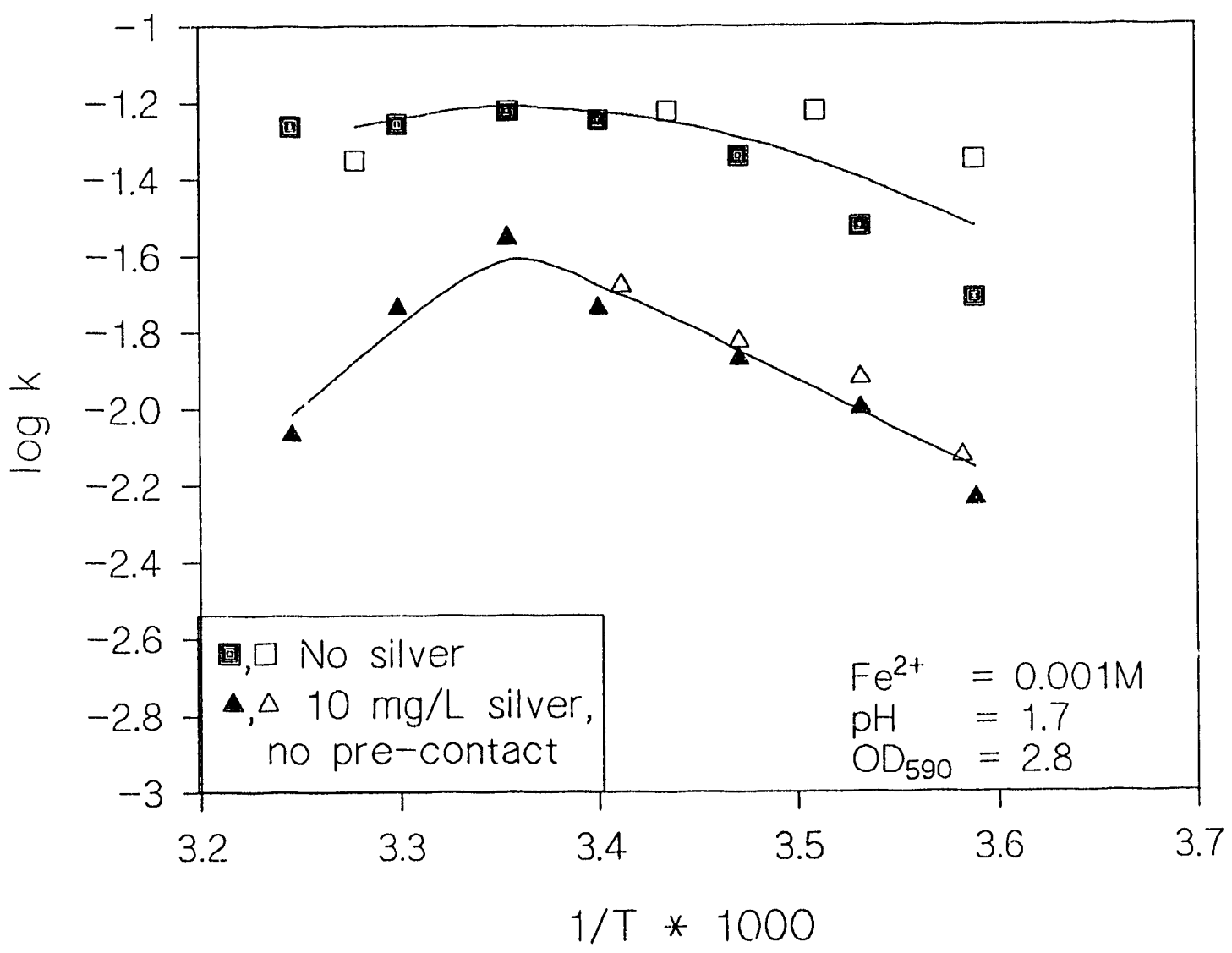

Fig. 20 Arrhenius plot for the bacterial oxidation of Fe(II) in the absence and in the presence of silver $(10 \mathrm{mg} / \mathrm{L})$. 


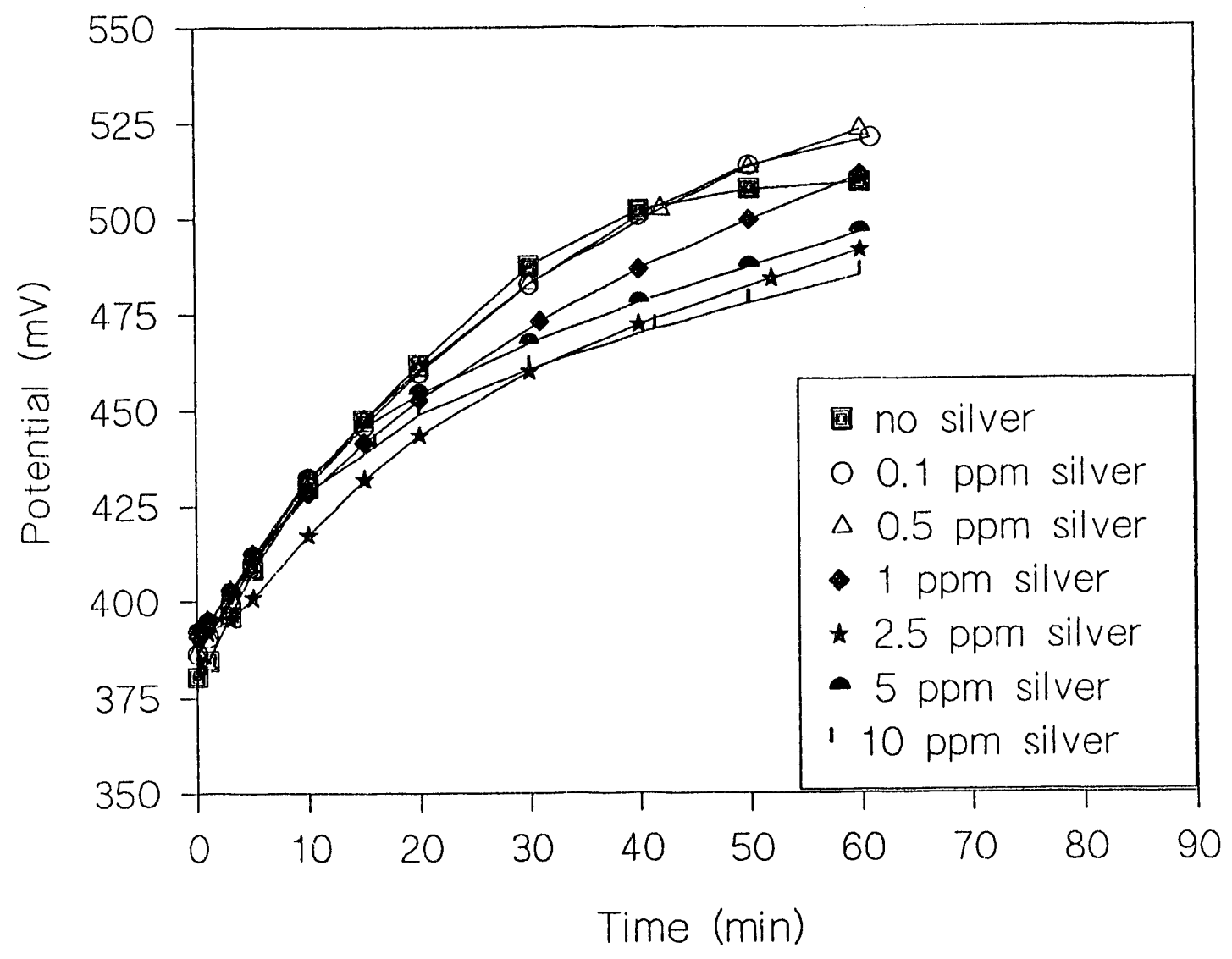

Fig. 21 Effect of silver concentration on the redox potential of solution during microbial oxidation of Fe(II). There was no conditioning of bacteria with silver. 


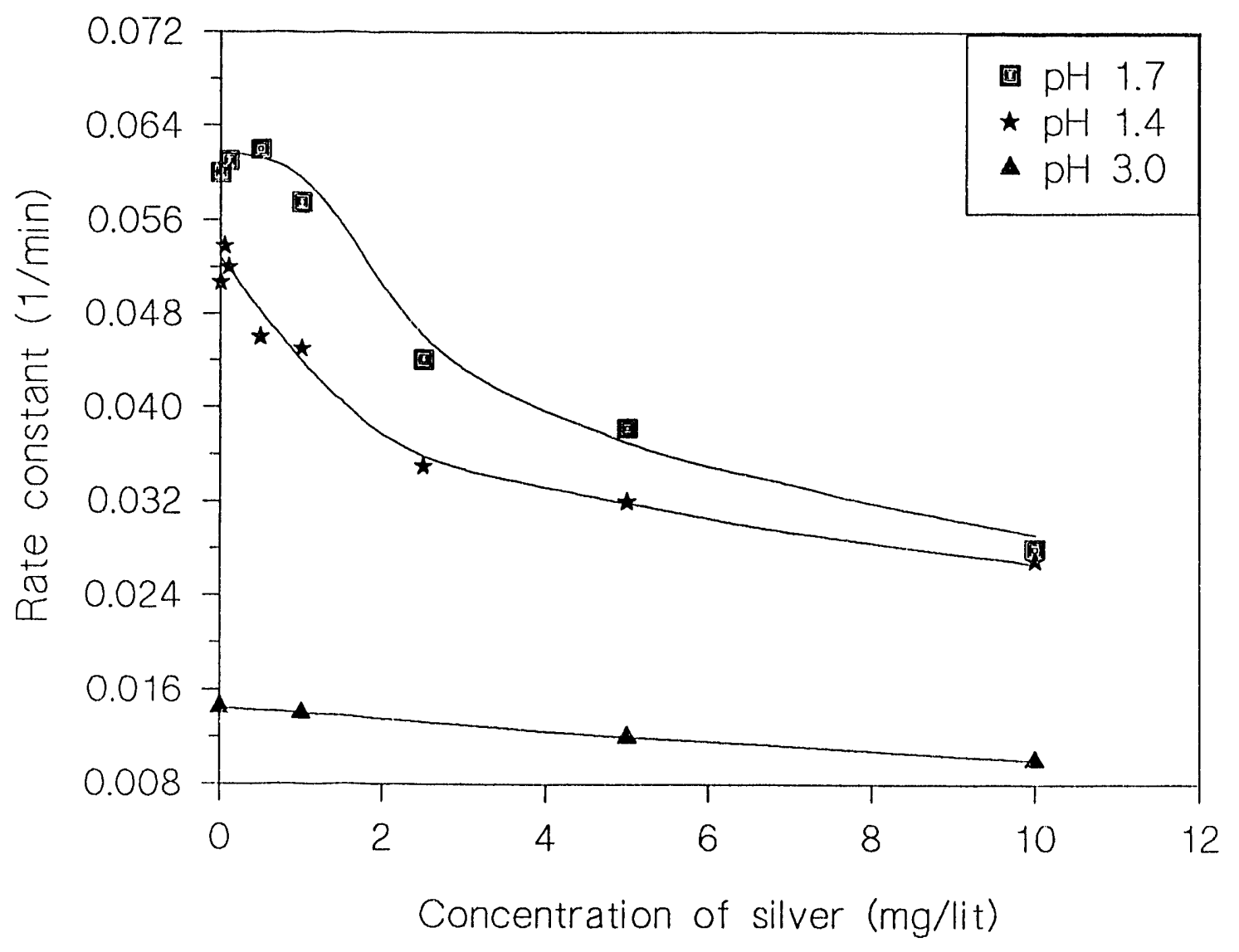

Fig. 22 Effect of silver concentration on the rate of microbial oxidation of $\mathrm{Fe}(\mathrm{II})$ at three different initial $\mathrm{pH}$ values. There was no conditioning of bacteria with silver. 


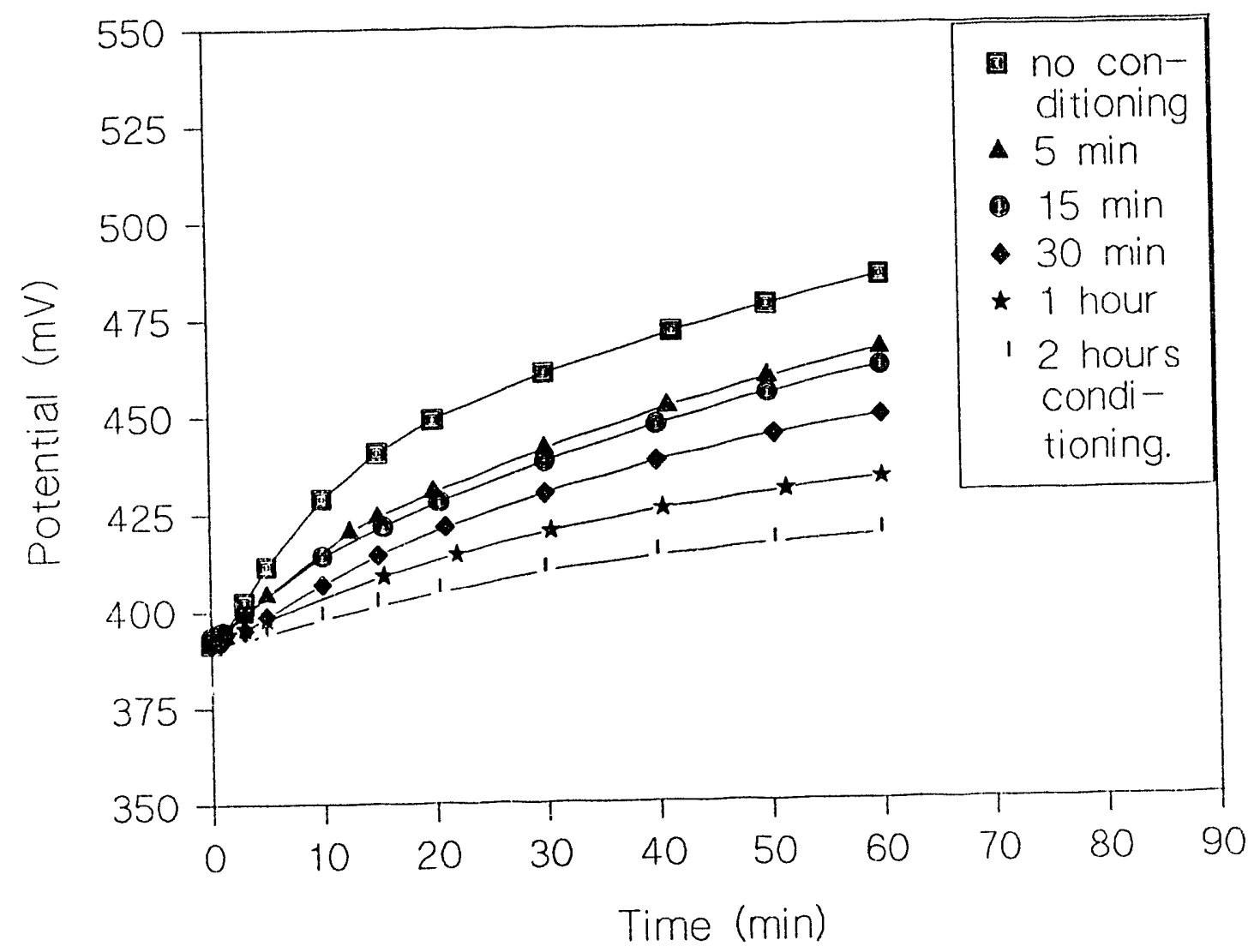

Fig. 23 Effect of time on the redox potential of pyrite electrode during microbial oxidation of Fe(II). Bacteria was conditioned with solutions containing silver (10 $\mathrm{mg} / \mathrm{L})$. 


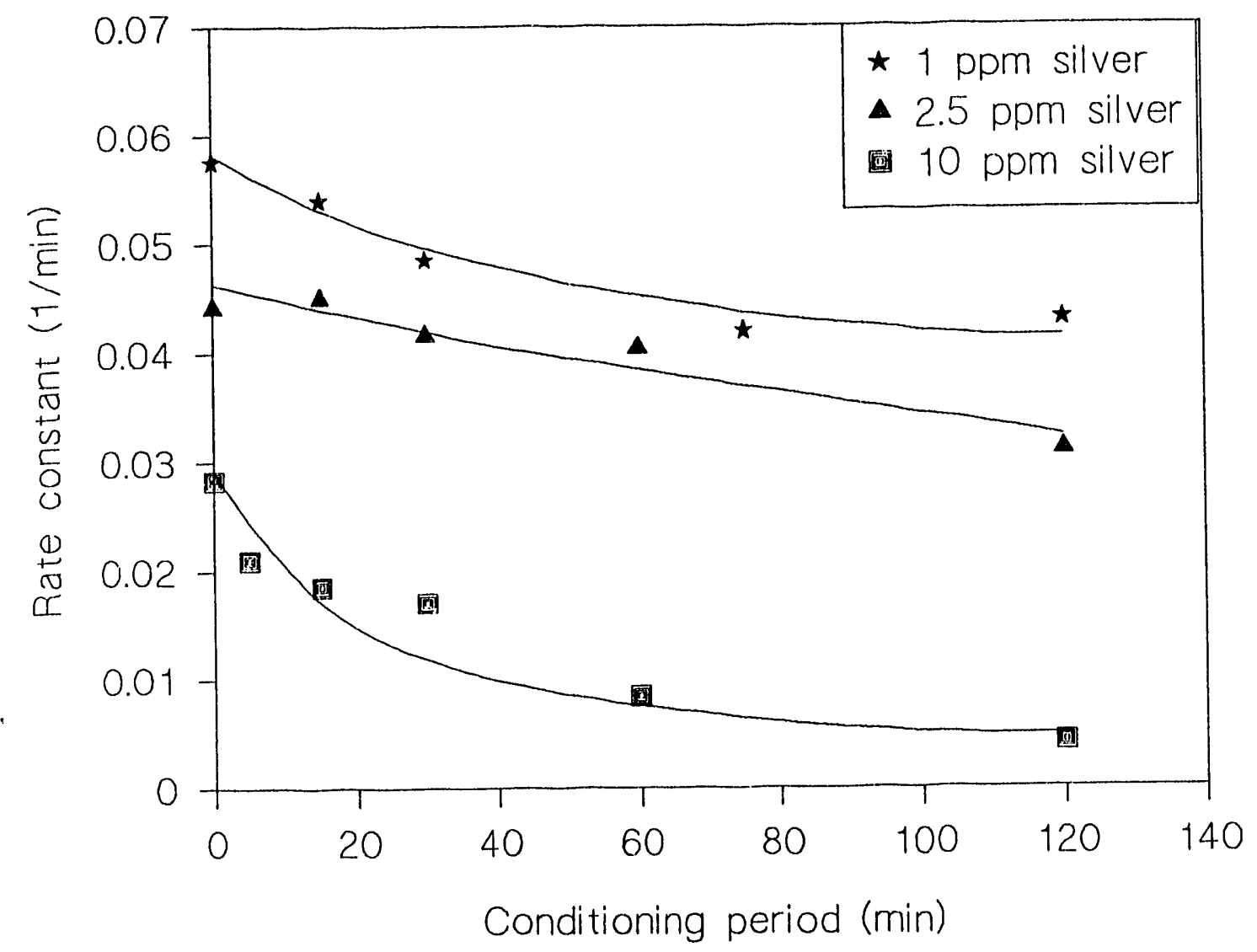

Fig. 24 Rate constant of microbial oxidation of Fe(ll) as a function of conditioning time of bacteria with silver containirig solutions. 


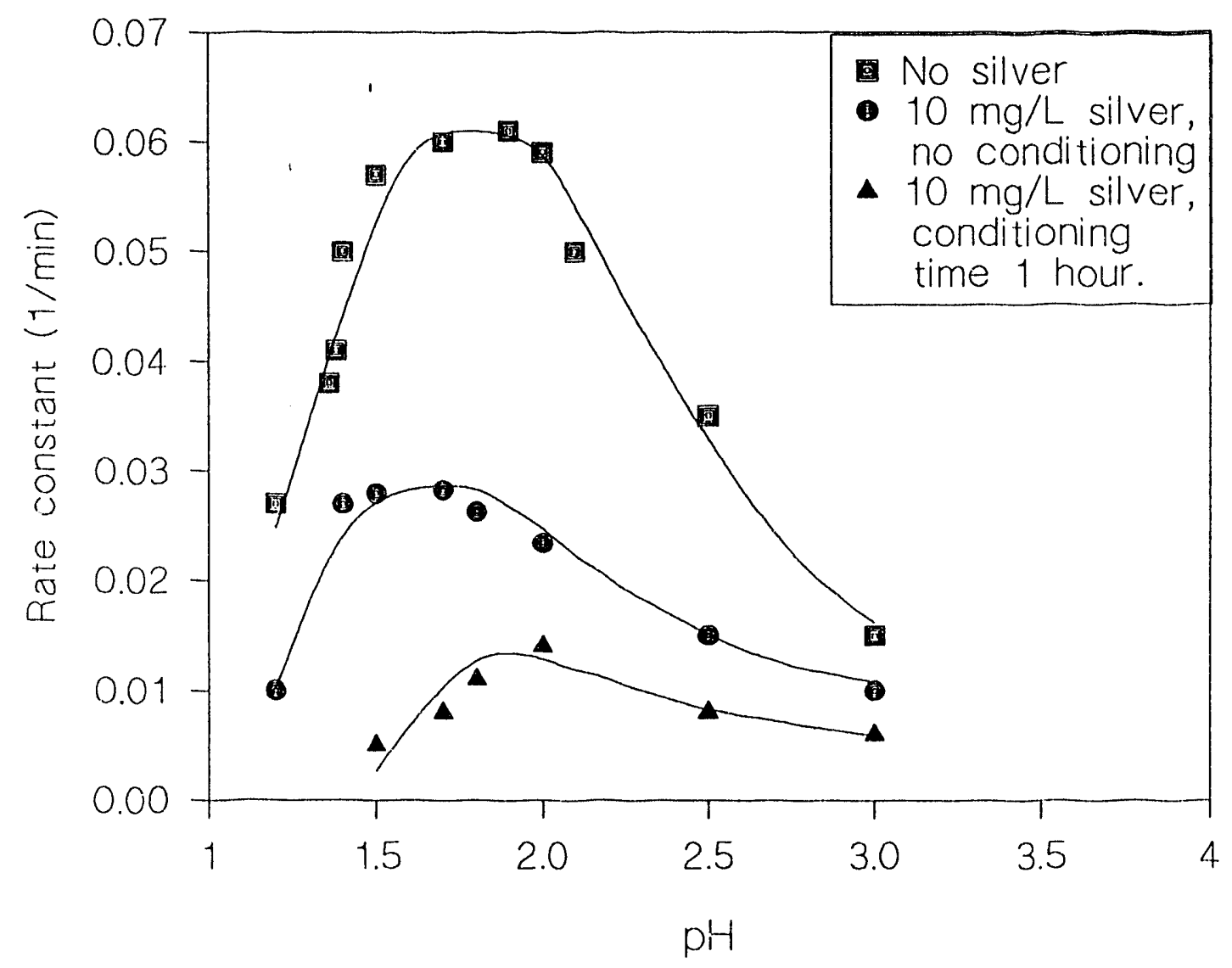

Fig. 25 Effect of $\mathrm{pH}$ on the rate constant of microbial oxidation of $\mathrm{Fe}(\mathrm{II})$ as a function of silver presence and conditioning time. 


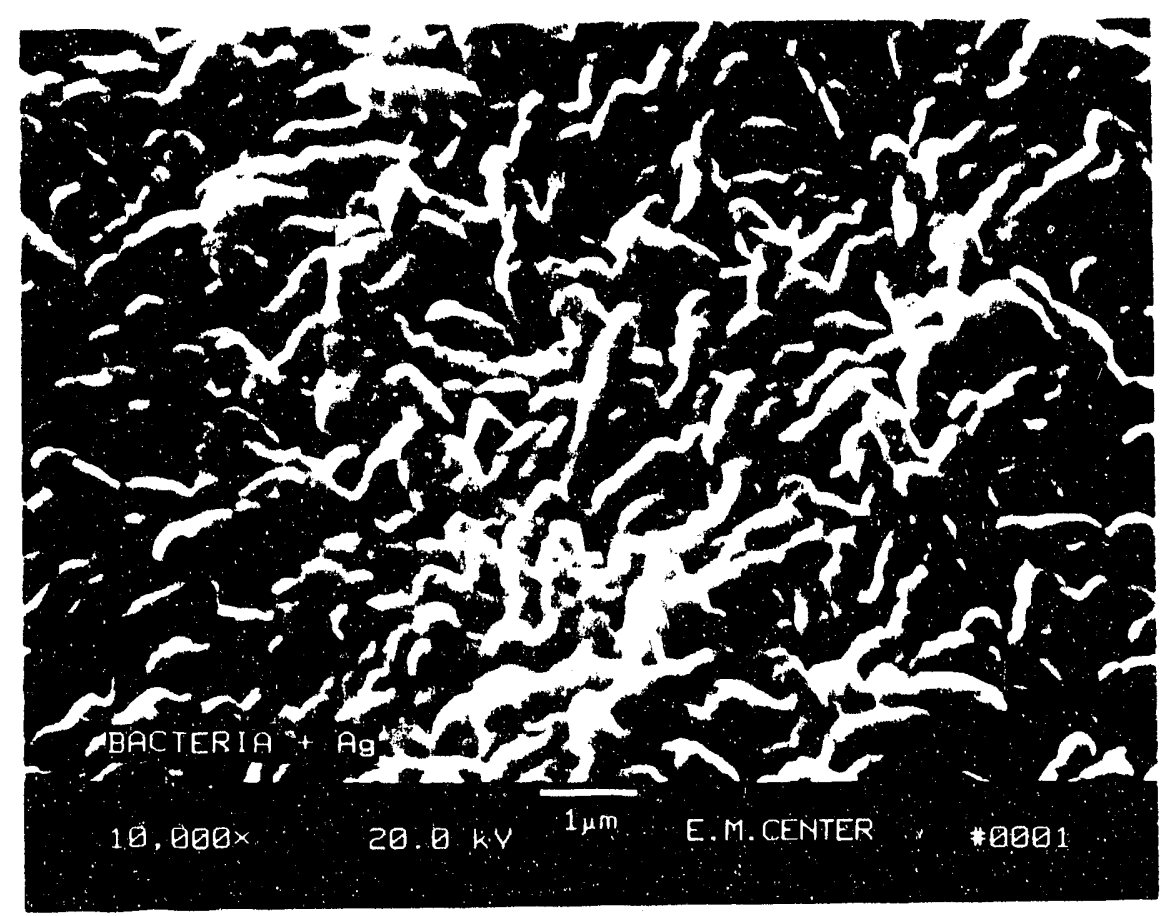

Fig. 26a SEM photomicrograph of T. ferrooxidans taken from an experiment of microbial oxidation of Fe(TI) in the presence of $2.5 \mathrm{mg} / \mathrm{I}$ sjlver. 


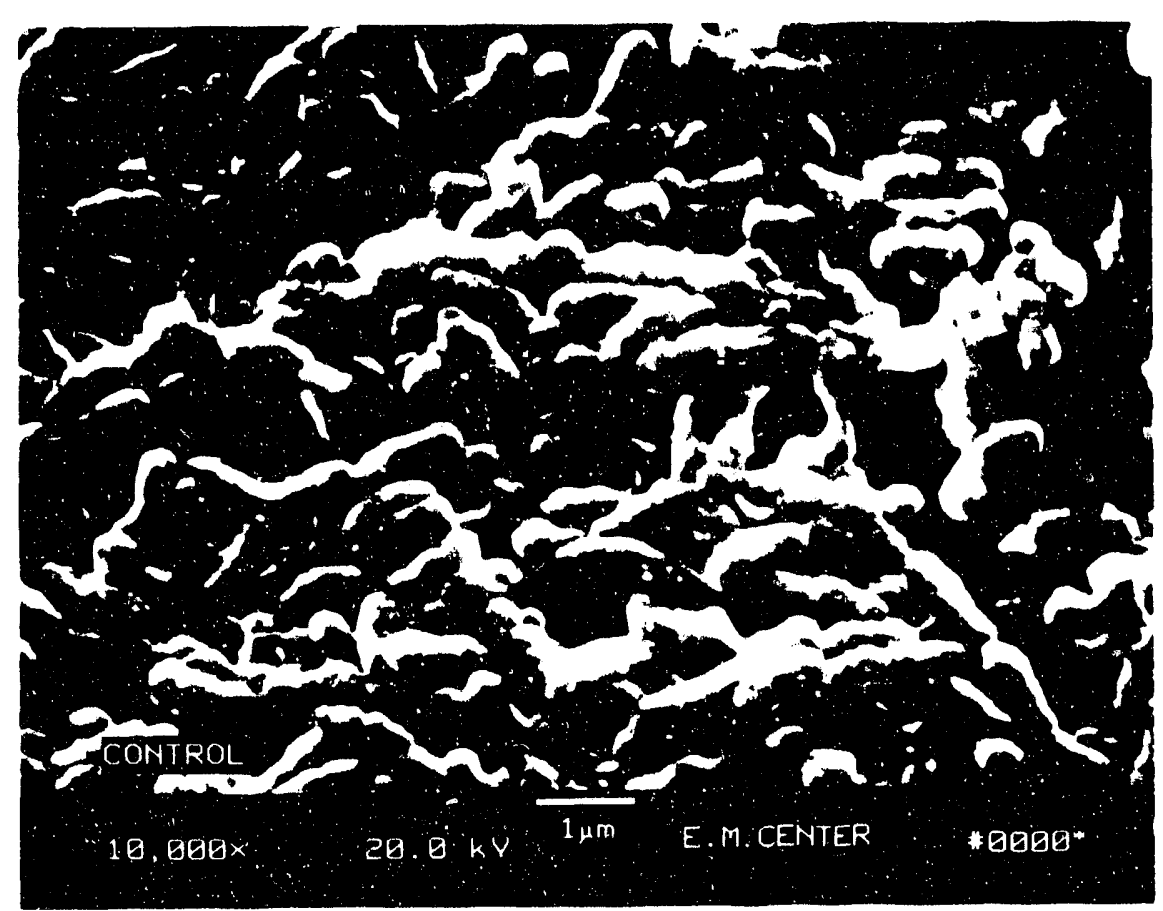

Fig. 26b SEM photomicrograph of $\mathrm{T}$. ferrooxidans taken from a control experiment (no silver) of microbial oxidation of Fe(II). 


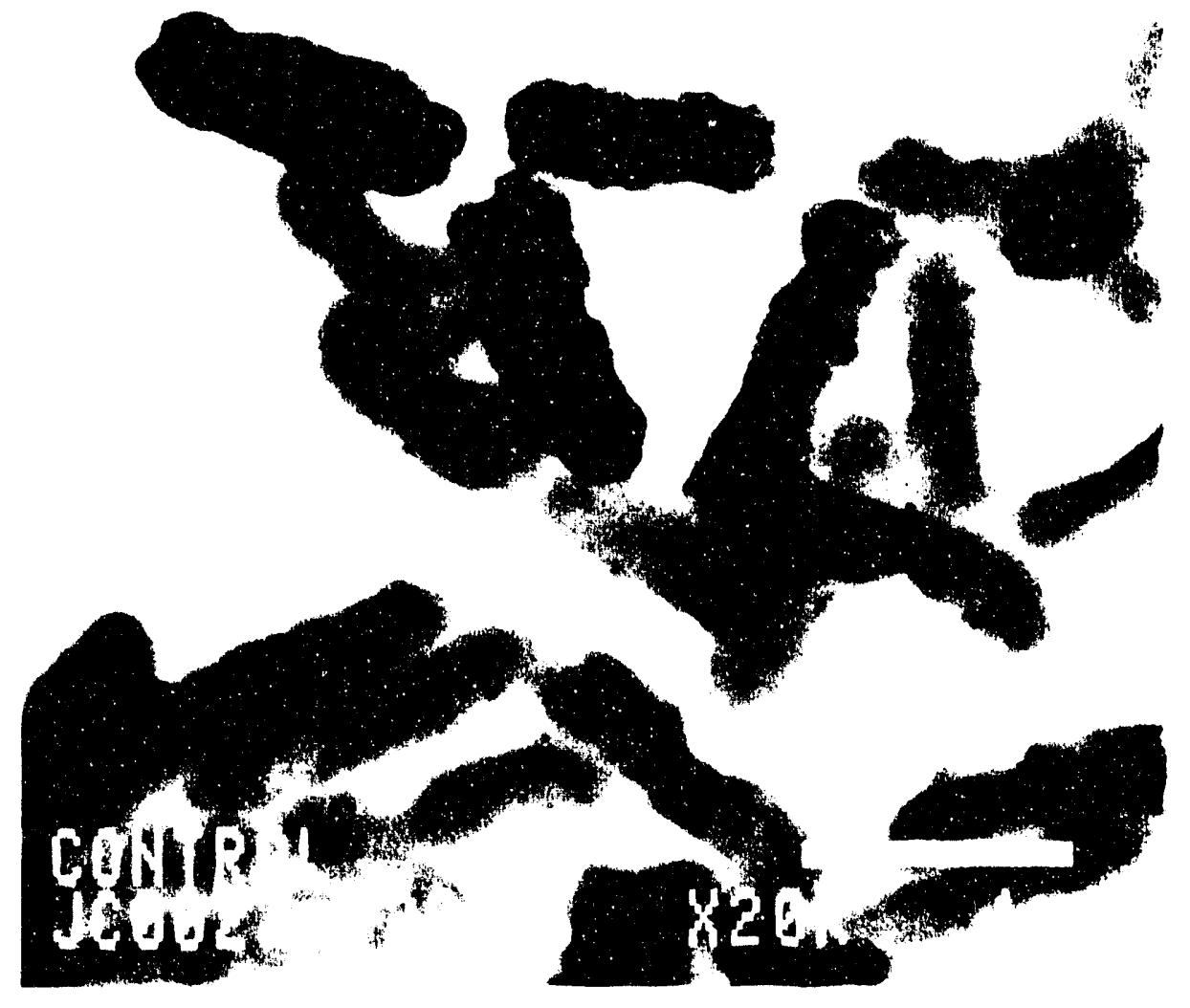

Fig. 27a TEM photomicrograph of T. ferrooxidans taken from a control experiment (no silver) of microbial oxidation of Fe(II). 


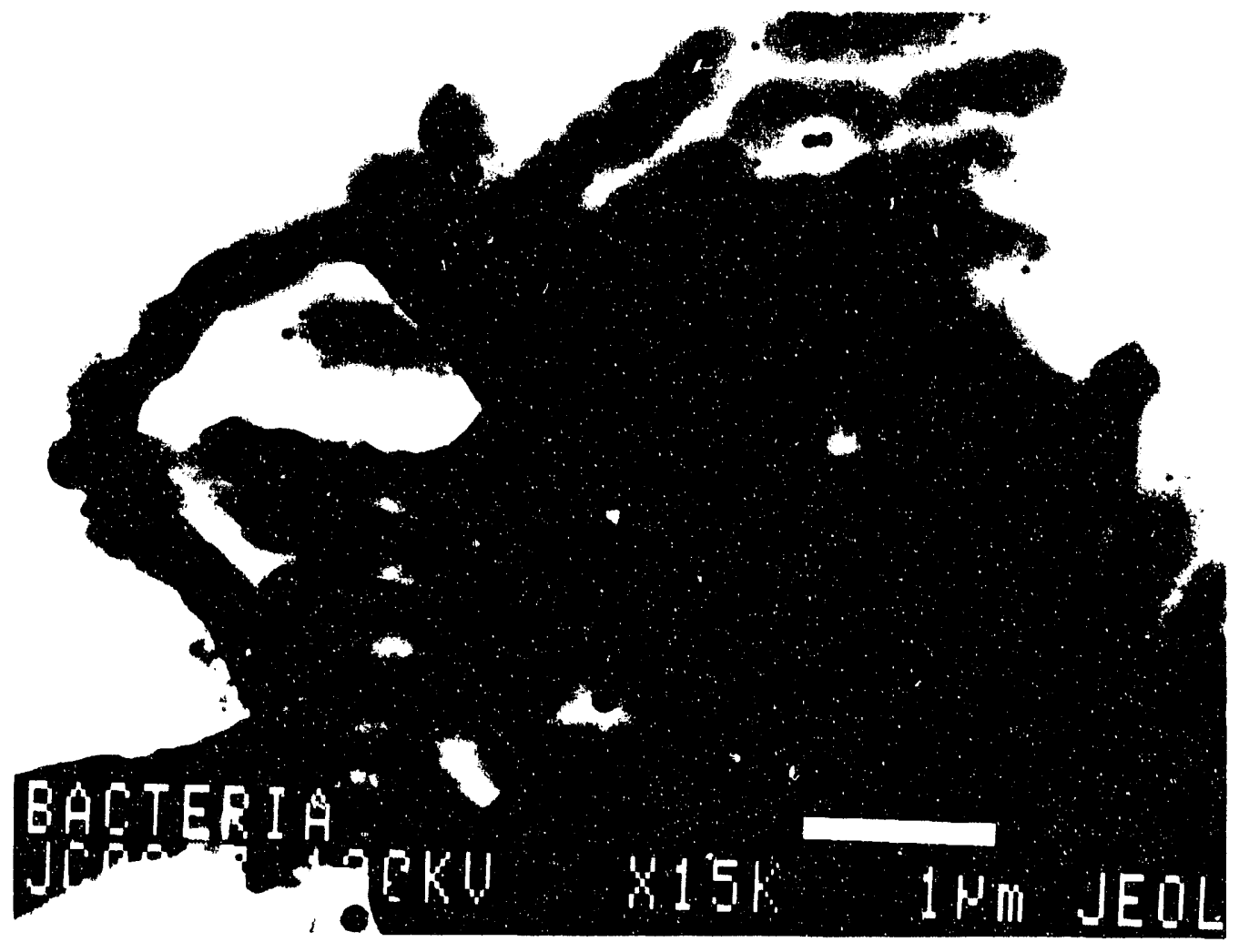

Fig. 27 b) TEM photomicrograph of T. Eerrooxidans taken from an experiment of microbial oxidation of Fe(II) in the presence of $2.5 \mathrm{mg} / \mathrm{I}$ silver. 


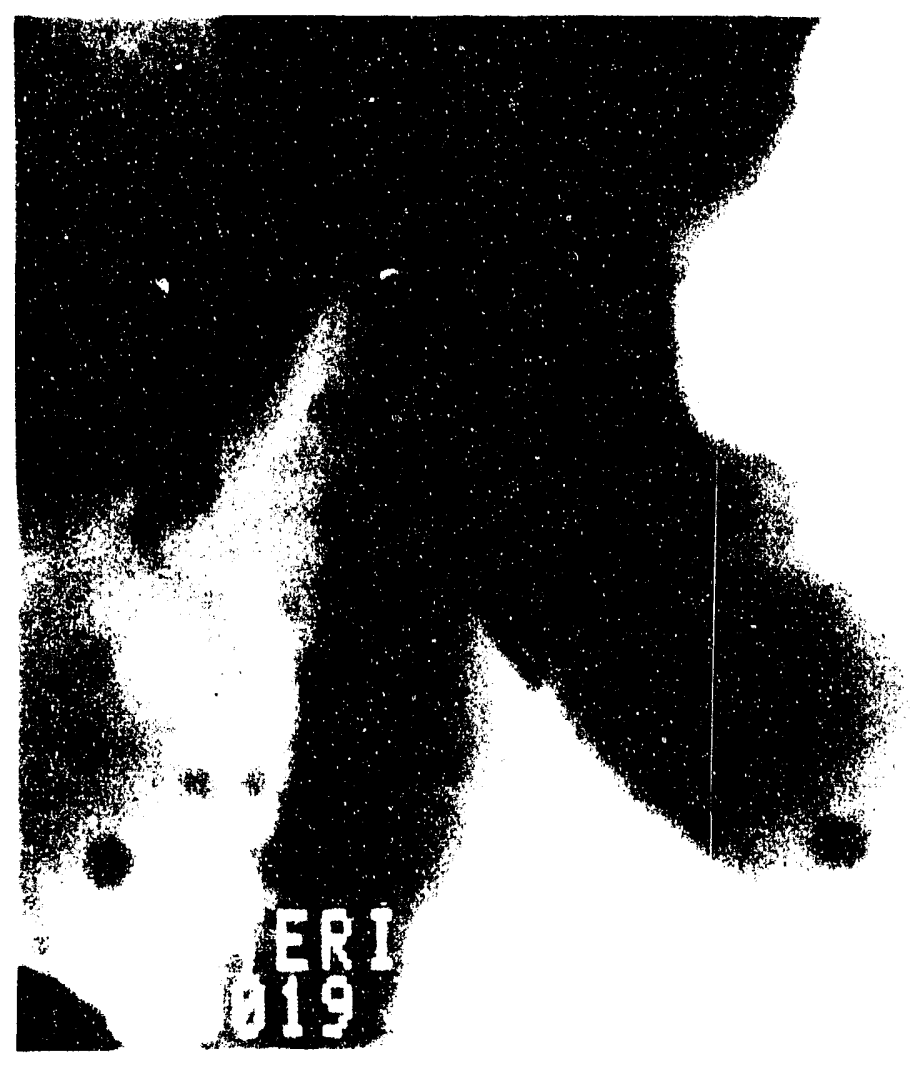

Fig. 27 C) Higher magnification of TEM photomicrograph of $\mathrm{T}$. ferrooxidans taken from an experiment of microbial. oxidation of $\mathrm{Fe}$ (II) in the presence of $2.5 \mathrm{mg} / \mathrm{L} \mathrm{Fig.}$ 


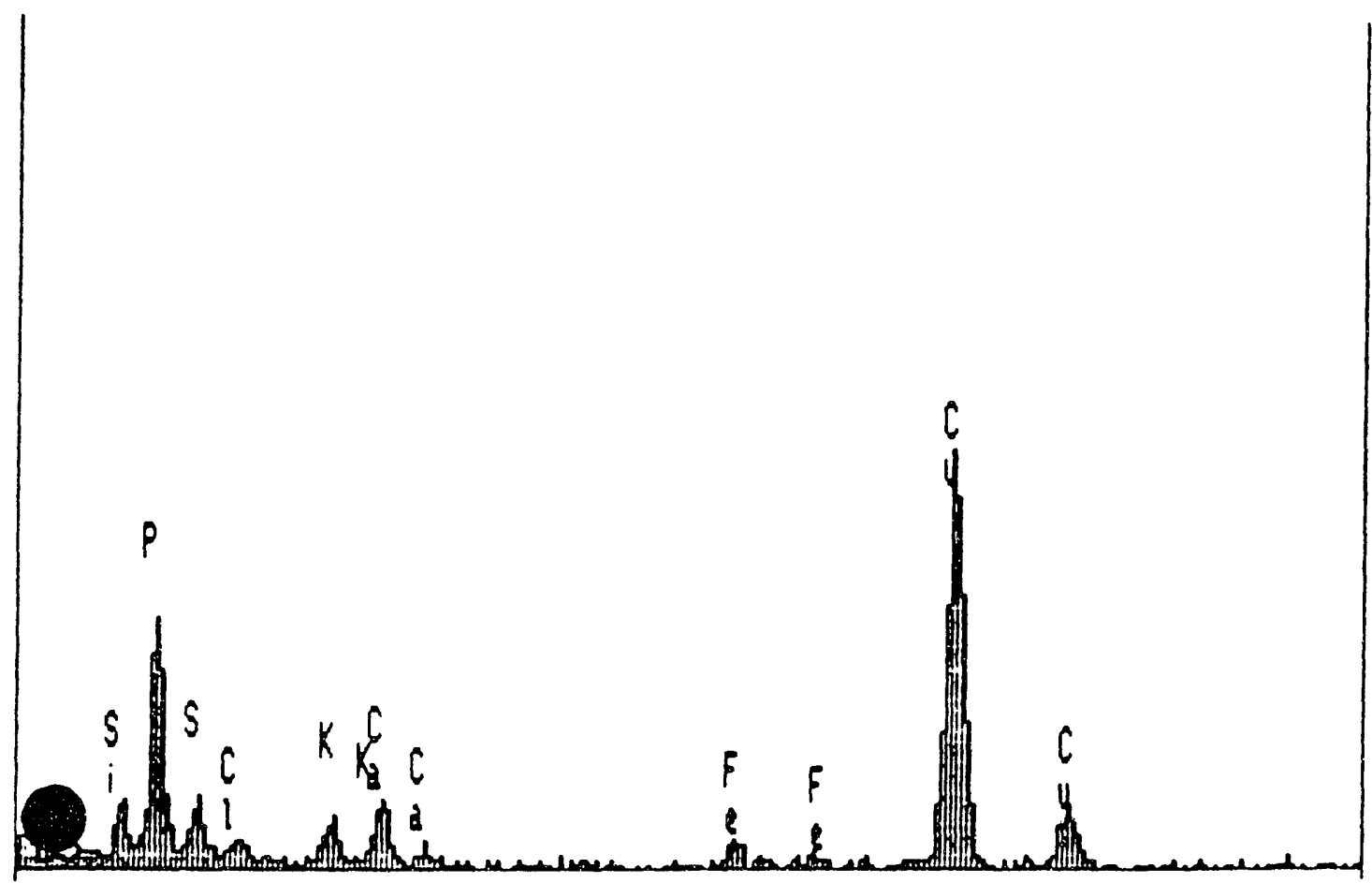

Fig. 28a X-ray emission of spectrum (EDX) of the lighter area of the bacteria cell in Fig. 27a. 


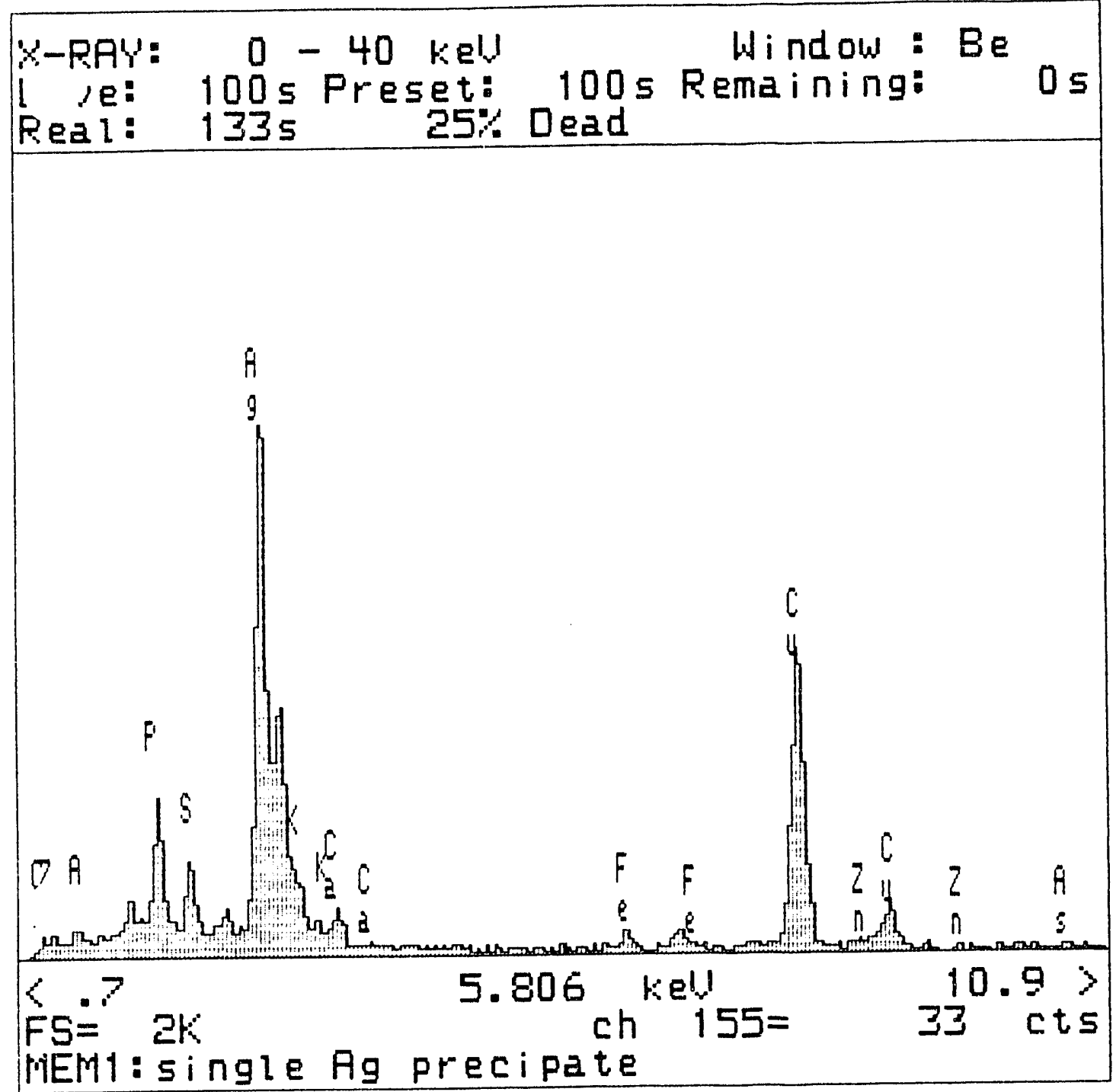

Fig. 28b X-ray emission of spectrum (EDX) of a dark spot of the bacteria cell in Fig. 27b. 


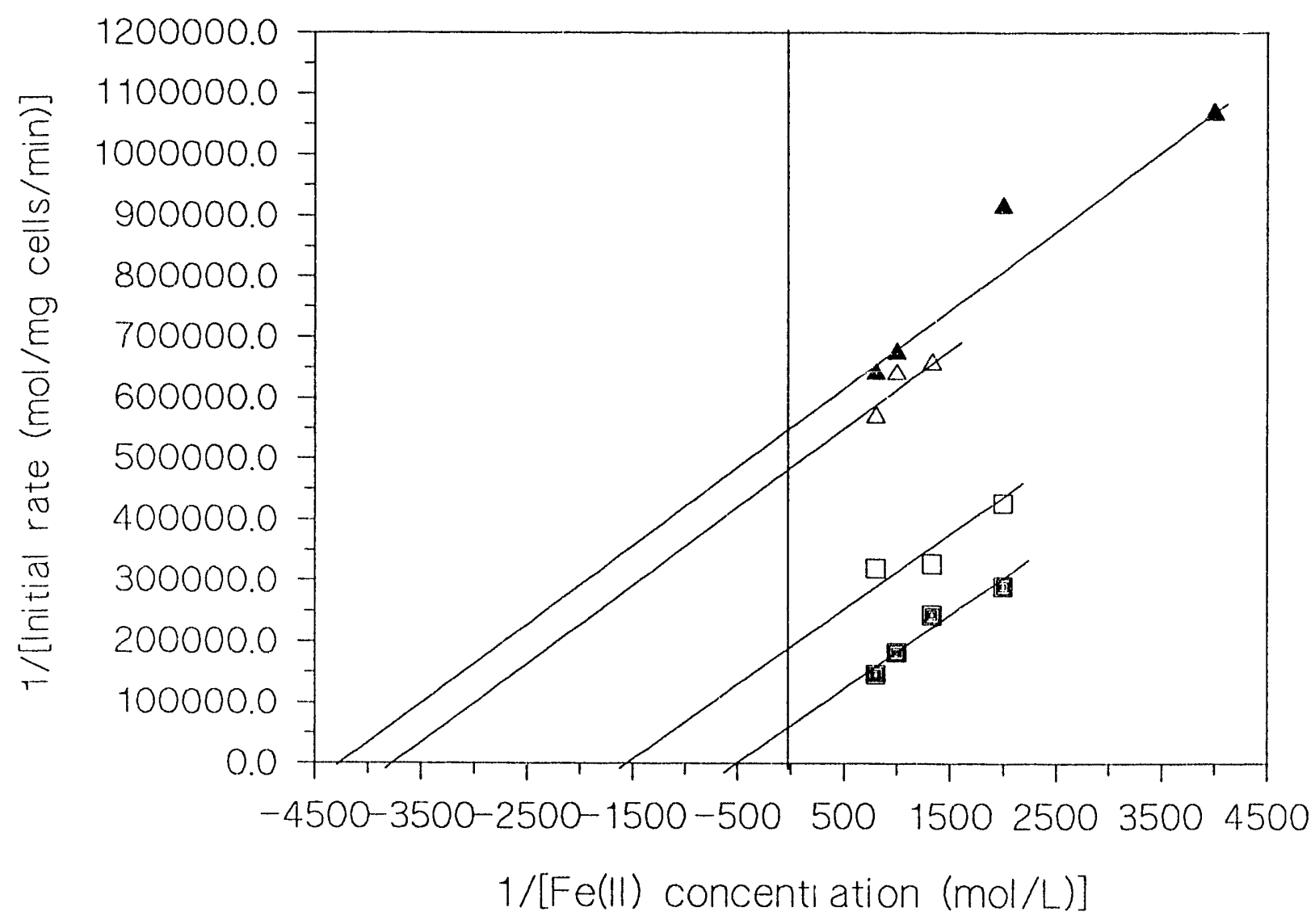

Fig. 29 Lineweaver-Burk plot for microbial oxidation of Fe(II) in the absence (squares) and in the presence of $10 \mathrm{mg} / \mathrm{L}$ mercury (Closed symbols: data from redox potential measurements; Open symbols: data from optical density measurements). 


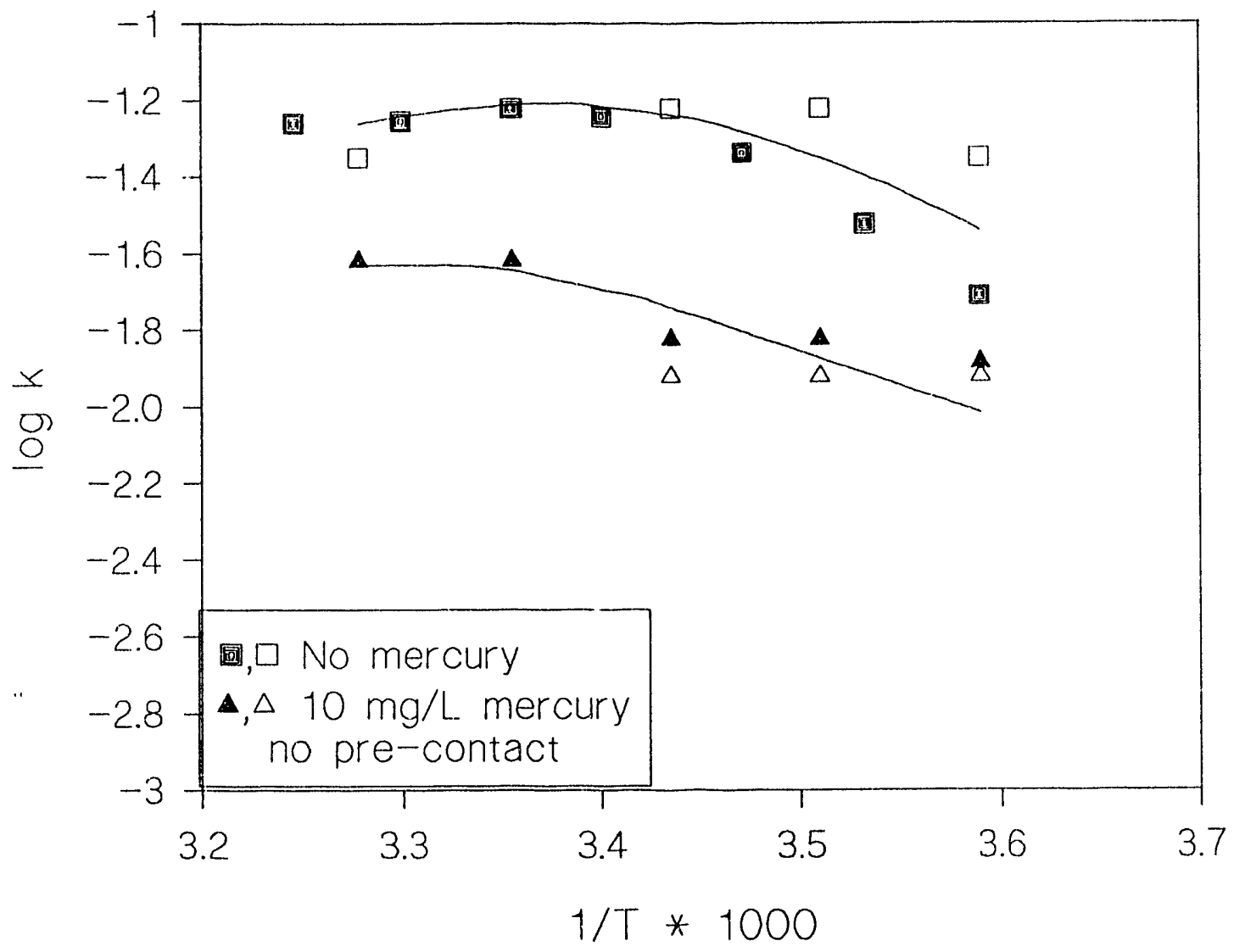

Fig. 30 Arrhenius plot for the bacterial oxidation of $\mathrm{Fe}(\mathrm{II})$ in the absence and in the presence of mercury $(10 \mathrm{mg} / \mathrm{L})$. 
CHAPTER III

\section{REDOX POTENTIAL TECHNIQUE TO STUDY THE FACTORS OF IMPORTANCE DURING REACTIONS OF T. ferrooxidans WITH $\mathrm{Fe}^{2+}$}

\section{INTRODUCTION}

Understanding the interactions of Thiobacillus ferrooxidans with sulfide minerals is important from both the metallurgical and the environmental points of view. In metallurgical applications, T. ferrooxidans can be used for the oxidation of pyrite to liberate encapsulated gold (1), or to produce ferric iron and acid for copper leaching in dumps/heaps (2). This bacterium can also be useful in cleaning coal from pyrite (3), but it can be environmentally detrimental because of its role in the oxidation of sulfide minerals in mineralized zones and the subsequent release of heavy metals into mine waters (4). In either case, successful control depends on understanding how $\mathrm{T}$. ferrooxidans interacts with pyrite.

Although important, the pertinent reaction mechanisms have received only limited study, most of it focusing on the suitability of ores, coals, and cultures for bioleaching. In practical terms, the successful bioleaching of sulfides depends on the two most important biological parameters, growth, i.e. concentration of cells, and activity, i.e. the affinity of the organisms for sulfides and ferrous iron. Many studies have examined the factors influencing these two parameters, some of which are related to the 
composition of the growth medium. Appropriate kinetic studies are required to define the effect of solution composition on bacterial growth rate and activity. Growth studies under batch and continuous (chemostat) conditions are typically used. The growth rate of $T$. ferrooxidans and its affinity for ferrous iron are studied from the rate of oxygen consumption by using classic manometric techniques.

To derive energy, T. ferrooxidans must continuously convert ferrous into ferric iron. This phenomenon results in a continuous increase in the redox potential of the medium, so that a change of redox potential with time represents either the growth rate or the affinity of cells for oxidation of ferrous iron. Therefore, with respect to $\mathrm{T}$. ferrooxidans, measuring the change in redox potential with time can represent a new technique for studying the effect of various factors on metabolism, growth, and affinity for ferrous iron.

In this study, the redox potential technique was used to examine the effects of important solution parameters on the growth of $\mathrm{T}$. ferruoxidans and its affinity for ferrous iron oxidation. This two-part study deals first with bacterial growth, and secondly with the activity of the harvested cells.

\section{EXPERIMENTAL DETAILS}

\section{Culture Preparation}

All solutions and glassware were st_erilized before use in an 
autoclave. Analytical grade salts were used for preparing nutrient medium (Table 7), which was adjusted to $\mathrm{pH} 2.0$ with $\mathrm{H}_{2} \mathrm{SO}_{4}$. The active cultures for inoculation were maintained in 500-ml Erlenmeyer flasks by adding $10 \mathrm{ml}$ of bacteria (strain ATCC 13598) to $250 \mathrm{ml}$ of medium, to which $5 \mathrm{ml}$ of ferrous sulfate stock solution $\left(37.5 \mathrm{~g} \mathrm{FeSO} \times 7 \mathrm{H}_{2} \mathrm{O} / 100 \mathrm{ml}\right.$ ) was added as the energy source. The flasks were incubated at $25^{\circ} \mathrm{C}$ in an incubator shaker (Lab-Line) at 250 rotations per minute.

Table 7 The Composition of Medium Solution ( $/ 1 / 1$.

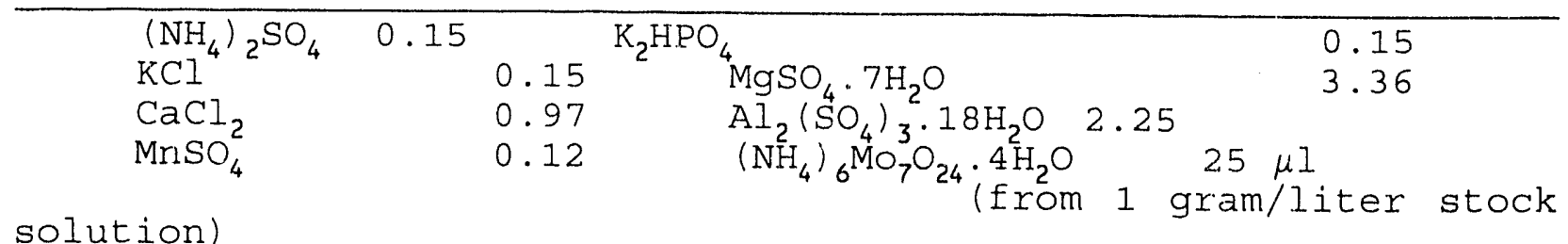

\section{Fermentation/Growth and Harvesting}

Fermenter: A custom-built fermenter for growing bazteria consisted of a 2 -liter glass kettle reactor and a cover with four ports. The kettle was maintained in a water bath at $25^{\circ} \mathrm{C}$. A glass tube was placed through one of the cover ports to supply air to the system and to stir the solution.

Growth and Harvesting: The growth of I. ferrooxidans was initiated by introducing a 5 -day inoculum into 2 liters of medium containing $50 \mathrm{~g}$ of $\mathrm{FeSO}_{4} \times 7 \mathrm{H}_{2} \mathrm{O}$. After 5 days' growth, the bacteria were 
harvested by separating the bacteria from the solid iron precipitates by filtration on a vacuum filter (Whatman \#1). The filtrate was then passed through a $0.1-\mu \mathrm{m}$ membrane filter (Millipore MiniTan) which retained the organisms. The bacteria were further washed with 2 liters of acidified water ( $\mathrm{pH} 2.0$ ). After harvesting, the resulting $34 \mathrm{ml}$ of bacteria was stored in a graduated cylinder for experimental study.

\section{Electrochemical Cell}

The activity of harvested $\mathrm{T}$. ferrooxidans cells was measured by a small electrochemical cell consisting of a 500-ml beaker, electrolyte $(250 \mathrm{ml}$ of $0.001 \mathrm{M}$ ferrous iron solution, $\mathrm{pH} 2$; an indicator electrode, and a reference electrode (SCE-standard calomel electrode). The indicator electrode was made of pure mineral pyrite (Ward's Geological Services) by casting a cut pyrite $(5 \mathrm{~mm} \times 5 \mathrm{~mm} \times 10 \mathrm{~mm})$ into a suitable mold with casting resin. The contact between the copper lead wire and the pyrite was made with silver conductive epoxy.

Pyrite is an excellent material for indicator electrodes. Although not as chemically inert as platinum, it is inert enough to be suitable in most chemical systems. Its clear advantage is that it achieves equilibrium potential very rapidly, usually within 1-2 seconds, as compared to several minutes for platinum. The reproducibility of pyrite electrodes is excellent. Even without polishing, this electrode can reproduce redox potentials with 1-2 mV, while a platinum electrode suffers from the well-known 
"poisoning" effects, and its reproducibility is difficult to obtain even within 10-15mV. During each experiment, the redox potentials were acquired (LabTech Notebook Data Acquisition with Strawberry Tree Computers Interface) every minute by a computer.

\section{Experimental Procedure}

The overall study was divided into two parts. The objective of Part I was to examine bacterial growth under various solution conditions. The objective of Part II was to examine the effect of various parameters on the activity of the cells harvested after growth under standard conditions.

Throughout the study, an experiment always consisted of inoculation, growth, harvesting, and measuring the activity of the harvested bacteria. The measurement of bacterial activity was performed in the electrochemical cell by using the redox potential method (15). A fixed volume $(2 \mathrm{ml})$ of harvested bacterial cells was added to the electrolytic cell containing $250 \mathrm{ml}$ of $0.001 \mathrm{M}$ ferrous iron solution at $\mathrm{pH} 2.0$. Adding the harvested $\mathrm{T}$. ferrooxidans cells to this solution caused oxidation of ferrous into ferric iron, increasing the redox potential, which was recorded with time. The change in redox potential with time represents the rate of iron oxidation by bacteria; that is, bacterial activity, or the affinity of bacteria for ferrous iron. The rate of iron oxidation is a function of cell concentration and bacterial activity.

When bacterial growth was studied as a function of various 
parameters (time, pH, medium composition, etc.) in Part I of this study, the actirity measured in the electrochemical cell represents the effect of the parameter studied on the resultant concentration of cells, or growth. In Part II, however, the cells were always grown under constant conditions in order to produce a constant amourit (concentration) of harvested cells. A fixed aliquot of harvested cells was then transferred into the electrochemical cell to measure activity as a function of a particular parameter within the solution (solution $\mathrm{pH}$, substrate concentration, etc.) used in the electrochemical cell. In part II, the rate of ferrous iron oxidation represents the activity of the cells as a function of the parameters of the solution in the electrochemical cell.

In either case, the experimental method assumes that the bacteria cell number did not change during measurement, an assumption justified by the rapidity of measurement (within 60 minutes) and the absence of salt components necessary for growth (i.e., the activity was measured in $0.001 \mathrm{M} \mathrm{Fe}^{2+}$ at $\mathrm{pH} 2$ ).

\section{Standard Experimental Conditions}

Standard experimental conditions are summarized in Table 8 . 
Table 8 Stanciard conditions during fermentation and activity measurement.

Fermentation Standard Conditions:

$\begin{array}{llll}\text { Volume } & =2 \mathrm{l} & \mathrm{FeSO}_{4} \cdot 7 \mathrm{H}_{2} \mathrm{O} & =50 \mathrm{~g} \\ \mathrm{pH} & =2 & \text { Time } & =5 \mathrm{days} \\ \text { Temperature } & =25 \mathrm{o}^{\circ} \mathrm{C} & \text { Medium } & =\text { in Table } 7\end{array}$

Standard Conditions to Measure Activity of Harvested Bacteria:

$\begin{array}{llll}\text { Volume } & =250 \mathrm{ml} & \mathrm{Fe}^{2+} & =0.001 \mathrm{M} \\ \text { pH } & =2.0\left(\mathrm{H}_{2} \mathrm{SO}_{4}\right) & \mathrm{Time} & =60 \mathrm{~min} \\ \text { Temperature } & =25{ }^{\circ} \mathrm{C} & & \end{array}$

Electrodes: Indicator-Mineral pyrite; Reference-Calomel

\section{RESULTS}

\section{Part I:}

\section{Effect of Various Parameters on Growth of $T$. ferrooxidans}

The effect of three parameters, $\mathrm{pH}, \mathrm{FeSO}_{4}$ concentration, and solution environment, on the growth of bacteria was examined by varyirg the parameters during growth (fermentation) under other standard experimental conditions. Each experiment was terminated after exactly five days of fermentation, and the cells were harvested. Aliquots of harvested cells were further transferred in:o the electrochemical cell to measure bacterial activity by using the redox potential measurement method. The resulting measurements of activity indirectly predict the effect of the parameter studied on the growth of bacteria. 
Effect of $\mathrm{pH}$

Although the objective was to examine the effect of $\mathrm{pH}$ on the growth of bacteria by measuring their activity after harvesting, the experimental opportunity was seized to monitor the variation in redox potential of the fermentation solution during growth.

Interpretation of Redox Potentials during Growth: The effect of $\mathrm{pH}$ on the growth of $\mathrm{T}$. ferrooxidans was investigated in the range of $\mathrm{pH}$ 1-5. The effect of $\mathrm{pH}$ is shown by the variation with time of the redox potential of the solution during fermentation, Fig. 31 (for clarity, the results from $\mathrm{pH} 4$ and $\mathrm{pH} 5$ not given). Fig. 31 shows four distinct regions of ferrous iron oxidation, exemplified by $\mathrm{pH} 3.5$. The first region corresponds to the initial oxidation of ferrous iron, and the other three regions reflect the growth phases of the bacteria. The initial iron oxidation occurred when the bacterial inoculum was transferred into the fermenter and began oxidizing ferrous into ferric iron for metabolic reasons, causing an increase of the solution redox potential.

After this initial phase of iron oxidation, the oxidation rate slows down. This and subsequent oxidation rates are relat.ed to the well-known lag, exponential, and stationary phases of bacterial growth, as shown in Fig. 31. The pH has a well-defined effect on the lag phase. At $\mathrm{pH} 1.0$, the bacteria remained in lag phase over the 5 days' incubation time (square symbols). At pH values ranging from 1.5 to 3.0 , the lag phase was much shorter. Further increase 
of $\mathrm{pH}$ again increased the length of lag phase (hexagonal symbols). At $\mathrm{pH} 4.0$ and 5.0 the lag phase was longer than the fermentation time (not shown). During the exponential growth phase that follows lag phase, the exponential increase in the number of cells directly correlates with the exponential increase in the rate of iron oxidation, $i . e .$, the exponential variation of redox potential with time. Exponential phase ends abruptly, and the slopes of lines corresponding to this growth phase are similar in the pH range 1.5-3.5, indicating that the exponential growth stage of $T$. ferrooxidans growth depends very little on $\mathrm{pH}$ in this range. In the last phase, stationary growth, pH had no effect. At pH 1.0, the bacteria never reached this phase.

Activity of Harvested Cells: The effect of $\mathrm{pH}$ on the growth of $\mathrm{T}$. ferrooxidans was indirectly measured by the redox potential method in the electrochemical cell, using the cells harvested after 5 days' growth at each pH. Each batch of harvested bacteria grown at the given $\mathrm{pH}$ always had the same volume, $34 \mathrm{ml}$. Exactly $2 \mathrm{ml}$. of the harvested cells was transferred into the electrochemical cell to test the rate of oxidation of a known concentration, $0.001 \mathrm{M}$, of ferrous iron. The consequent rates of ferrous iron oxidation represent the effect on the rate of cell concentration, which, because of fixed conditions in the electrochemical cell, can vary only if varying pH values affected growth, Fig. 32. The concentration of bacteria cannot change while activity is being measured because of the short (60 minute) test 
period, and because the test solution contained only ferrous iron without the salt components necessary for growth.

The effect of $\mathrm{pH}$ on the growth of T. ferrooxidans, Fig. 32, was dramatic. From pH 1.0-1.5, bacterial cell concentration increased sharply, from pH 1.5-3.0 it changed very little, above pH 3.0 it declined quite sharply, and at $\mathrm{pH} 4.0$ and above no growth was seen. The measurements of the activity of harvested cells, Fig. 32, correlate very well with the variation in redox potential of the growth medium, Fig. 31 .

Effect of Time on the Growth of $\mathrm{T}$. Eerrooxidans

The effect of time on the growth of $T$. ferrooxidans was studied in a series of experiments in which bacteria were grown under standard condjtions (Table 8) for various periods ranging from 0-24 days. At the end of each experiment, the bacteria were harvested and their activity measured by using the electrochemical cell and the redox potential method. Because bacterial activity was measured under constant experimental conditions (Table 8), the results were a function only of the concentration of harvested bacteria, which depended on the length of fermentation, Fig. 33 . In Fig. 33, the three characteristic phases of bacterial growth are represented by sections I-II; sections III-IV represent the death phase. (Section I, lag phase, is forced to the left on the graph due to the scale of $\mathrm{x}$-axis.)

The stationary phase is very short, occurring within the one- 
day interval represented by the two points on the border between II and III. The death phase made up of two stages. In the first stage (Fig. 33, III, days 5-8), the death rate was initially fast, and then slowed down from day 8-12 of fermentation. In the second stage of the death phase, after 12 days of fermentation (Fig. 33, IV), cells died rapidly. Death is caused mainly by the lack of an energy source after ferrous iron is converted to ferric, but in $\mathrm{T}$. ferrooxidans death can also be caused by the precipitation of jarosite on the cell walls. Pesic and $\operatorname{Kim}(17,64)$ have demonstrated that $\mathrm{T}$. ferrooxidans cells serve as the nucleation sites for jarosite formation. The jarosite formed envelops and penetrates the cells, the cell wall collapses, and the whole cell eventually is converted into a globule of jarosite.

\section{Effect of Environmental Conditions}

Since extracellular products of fermentation can impede the growth of bacteria, the effect of a fresh environment on the growth of $\mathrm{T}$. ferrooxidans was studied. The experimental procedure consisted of growth, harvest, and a series of transfers of harvested bacteria into fresh medium (Table 7) to continue growth. At the end of an experiment, the concentration of grown/harvested cells was indirectly measured by the redox potential method. After the first 5-day fermentation, the cells were harvested and moved into fresh medium to which 50 grams of $\mathrm{FeSO}_{4} \cdot 7 \mathrm{H}_{2} \mathrm{O}$ was added. After one day of fermentation, the cells were harvested, their activity checked, and they were again moved into fresh medium to which 50 
grams of $\mathrm{FeSO}_{4} \cdot 7 \mathrm{H}_{2} \mathrm{O}$ was added. It was expected that the cells would continue to grow and that by repeating these cycles of harvestingfermentation-harvesting in fresh medium salts, cell concentration would increase Iinearly because of the constant addition of food in each cycle. It was found that the concentrated bacteria, when transferred into the fresh medium + ferrous sulfate environment, oxidized all of the iron within one day of fermentation. However, when the cells were harvested and their concentration checked in the electrochemical cell by the redox potential method, it was found that exactly the same concentration of cells was produced in each cycle (horizontal part of the line in Fig. 34).

After seven one-day harvesting-fermentation-harvesting cycles were completed, it became apparent that the concentration of bacteria did not increase due to insufficient nutrient, since almost all the ferrous iron was oxidized within one day. Therefore, the one-day cycles in fresh medium were continued, but with an increased amount of $\mathrm{FeSO}_{4}$. Thus, when 75 grams of $\mathrm{FeSO}_{4} \cdot 7 \mathrm{H}_{2} \mathrm{O}$ was added and the bacteria harvested after one day of fermentation, the rate of iron oxidation as a measure of bacterial activity rapidly increased, indicating a higher concentration of cells. When 100 grams of $\mathrm{FeSO}_{4} \cdot 7 \mathrm{H}_{2} \mathrm{O}$ was added, a very high concentration of bacteria was produced. A final experiment was performed with 125 grams of $\mathrm{FeSO}_{4} \cdot 7 \mathrm{H}_{2} \mathrm{O}$, but the resulting cell concentration was so high that the cells plugged the membrane filter, forcing the harvesting step to be terminated, as well as the study of the effect of fresh medium + ferrous sulfate. 
To further establish that environmental conditions are important for the successful growth of $T$. ferrooxidans, five separate fermentation experiments were performed, each using a different amount of $\mathrm{FeSO}_{4} \cdot 7 \mathrm{H}_{2} \mathrm{O}: 25,50,75,100$ and 150 grams. After a 5-day fermentation period the cells were harvested and their concentration checked by the redox potential method. The concentration of $\mathrm{T}$. ferrooxidans cells was found to increase as the amount of ferrous sulfate increased, but not nearly at the same rate as when the bacteria were moved into a fresh medium + ferrous sulfate solution. For example, for 100 grams of $\mathrm{FeSO}_{4} \cdot 7 \mathrm{H}_{2} \mathrm{O}$, the rate was only $0.087 \mathrm{M} / \mathrm{min}, \mathrm{Fig} .35$, compared to $0.206 \mathrm{M} / \mathrm{min}$, Fig. 34 . 
Part II

\section{Effect of Ferrous Sulfate Concentration and pH on Activity of Harvested Cells}

The objective of Part II of this study was to examine the effect of substrate concentration and $\mathrm{pH}$ on the activity of $\mathrm{T}$. ferrooxidans by using the redox potential measurement technique. Cells were grown as before, under standard fermentation conditions (Table 8). Under constant growth conditions, it was expected that the amount of harvested bacteria would be constant after each fermentation batch. Because each batch of harvested cells was stored in exactly the same volume $(34 \mathrm{ml})$, the concentration of cells available for experimentation was also constant. Further, to avoid the effects of fluctuating concentrations of harvested cells from batch to batch, one batch of harvested cells was used for the complete study of the effect of each parameter. This approach guaranteed that the concentration of harvested cells could fluctuate only between studies of different parameters, but not within the study of any given parameter. Therefore, the observed effects were truly the effects of the studied parameter.

\section{Effect of Ferrous Sulfate Substrate Concentration}

This effect of ferrous sulfate substrate concentration was studied by adding a 2-ml aliquot of harvested cells $10.5 \mathrm{mg}$ dry weight $/ \mathrm{ml}$ ) to $250 \mathrm{ml}$ of solution, $\mathrm{pH} 2.0$ (Table 8). The ferrous iron substrate concentration varied in the range $0.0002 \mathrm{M}$ to 0.0035 
M. The initial rate of ferrous iron oxidation was measured from the variation in redox potential with time by using the Nernst equation(5), Fig. 36 (for clarity, only the results from the addition of $2 \mathrm{ml}$ of bacteria are shown). Fig. 37 represents the rates obtained for ferrous iron oxidation with two different batches of bacteria, $1 \mathrm{ml}$ and $2 \mathrm{ml}$ per $250 \mathrm{ml}$ of solution.

Fig. 37 shows that the initial rate of ferrous iron oxidation increases as iron concentration increases, and at higher concentrations the curves reach the so-called saturation kinetics condition, as predicted by the well-known Michaelis-Menten enzyme kinetic model(54). This model consists of two kinetic parameters, $\mathrm{V}_{\max }$, the maximum rate of reaction, and $K_{M}$, the substrate concentration at which the rate reaches one-half of its maximum. Of the many methods of estimating these parameters, the most useful is the so-called Lineweaver-Burk or double reciprocal plot (54), by which the reciprocals of initial rates are plotted versus the reciprocals of substrate concentrations. In the resulting plot, the slope of the line represents $K_{M} / V_{\max }$, the intercept on the $x$-axis represents $-1 / K_{M}$, and the intercept on the $y$-axis represents $1 / V_{\max }$.

An important question was whether the rates of ferrous iron oxidation given by the redox potential measurement method could be used to obtain the Michaelis-Menten kinetic parameters. If this previously untried approach was successful, then the redox potential method would offer an alternative to the standard manometric technique for studying kinetics in the presence of $T$. ferrooxidans. The Lineweaver-Burk plot for the data in Fig. 37 is 
shown in Fig. 38. The data obey the required linear relationship, and show the general disadvantage of this kind of plot, the crowding of data points for the higher substrate concentrations. (An additional disadvantage is a high error of $1 /$ Rate for the low substrate concentrations.)

From Fig. 38, the calculated $K_{M}$ values were $0.336 \mathrm{mM}$ for 2 $\mathrm{ml}$ (1 $\mathrm{mg}$ dry weight) and $0.44 \mathrm{mM}$ for $1 \mathrm{ml}(0.5 \mathrm{mg}$ dry weight) of T. ferrooxidans cells. These values are lower than the value $0.96 \mathrm{mM}$ found by Kelly and Jones (48) (experiments $1-11$ in Table III, and the value $1.34 \mathrm{~mm}$ found by Norris, Barr, and Hinson (61). The calculated $\mathrm{K}_{M}$ values are also lower than the $\mathrm{K}_{M}$ values listed by Rossi (62) (Table 3-10). In general, different investigators have found different $K_{M}$ values, due to variations in experimental conditions and in the differing affinities of organism strains for ferrous iron. In this work, lower $K_{M}$ values could result from the fact that the rate of ferrous iron oxidation with $\mathrm{T}$. ferrooxidans was measured in $\mathrm{pH} 2.0$ solutions containing only iron without other medium salts.

The calculated $V_{\max }$ values from Fig. 38 were $0.0000816 \mathrm{M} /(\mathrm{min})$ (dry weight) for $2 \mathrm{ml}$ of bacterial cells, and $0.00009 \mathrm{M} /(\mathrm{min})$ (dry weight) for $1 \mathrm{ml}$ of bacterial cells. These values are close to the value of $0.00014 \mathrm{MFe}^{2+} / \mathrm{min}$ found by Kelly and Jones (48).

\section{Effect of $\mathrm{pH}$}

The effect of hydrogen ion concentration was not studied as 
intensively as the effect of substrate concentration. Most studies of this parameter have been performed to identify the optimum $\mathrm{pH}$ region for leaching of sulfjdes. [For studies of hydrogen ion concentration, see Torma (63) and Rossi (62).] To the author's knowledge, no work has been done to correlate the rate of iron oxidation with $\mathrm{pH}$, as in this work (results corresponding to Fig. 32, and below).

The effect of $\mathrm{pH}$ on the rate of ferrous iron oxidation with harvested $\mathrm{T}$. ferrooxidans cells was studied in the pH range 0.8 . 3.6. The initial ferrous iron concentration was $0.001 \mathrm{M}$, and 2 $\mathrm{ml}$ of bacteria ( $1 \mathrm{mg}$ dry weight) per $250 \mathrm{ml}$ of solution was used. The rates were calculated from the change in redox potential with time at each pH, Fig. 39. It can be seen that the biotic oxidation of ferrous iron is very sensitive to solution pH, especially in the $\mathrm{pH}$ region $0.8-1.5$, where the rate of oxidation increased sharply as $\mathrm{pH}$ increased. The fastest rate of oxidation occurred at $\mathrm{pH}$ 1.6-1.7. Above $\mathrm{pH}$, the rate of oxidation decreased as pH increased.

Although the plots in Fig. 39 and Fig. 32 both represent the effect of $\mathrm{pH}$, their comparison reveals some differences. Fig. 32 represents the effect of $\mathrm{pH}$ on the growth of $\mathrm{I}$. ferrooxidans (more precisely, on the amount of harvested cells), while Fig. 39 represents the effect of $\mathrm{pH}$ on the activity of harvested cells grown under constant pH conditions. Both growth, Fig. 32, and activity, Fig. 39, of T. ferrooxidans increased sharply with an increase in $\mathrm{pH}$ up to $\mathrm{pH}$ 1.5-1.6. Differences are seen above $\mathrm{pH}$ 
1.6. While the quantity of harvested cells produced by fermentation was constant in the $\mathrm{pH} 1.5-3.0$ region, the rate of iron oxidation by the harvested cells (grown under constant pH conditions) declined rapidly with $\mathrm{pH}$ increase in this region. Like the effect of ferrous iron concentration, the effect of $\mathrm{pH}$ on the rate of iron oxidation with harvested cells was found in solutions without other medium salts. It would be interesting to examine whether the same dependence on $\mathrm{pH}$ would be seen if the activity of harvested cells was studied in solutions containing all necessary medium salts. This part of the research will be done in the future. 


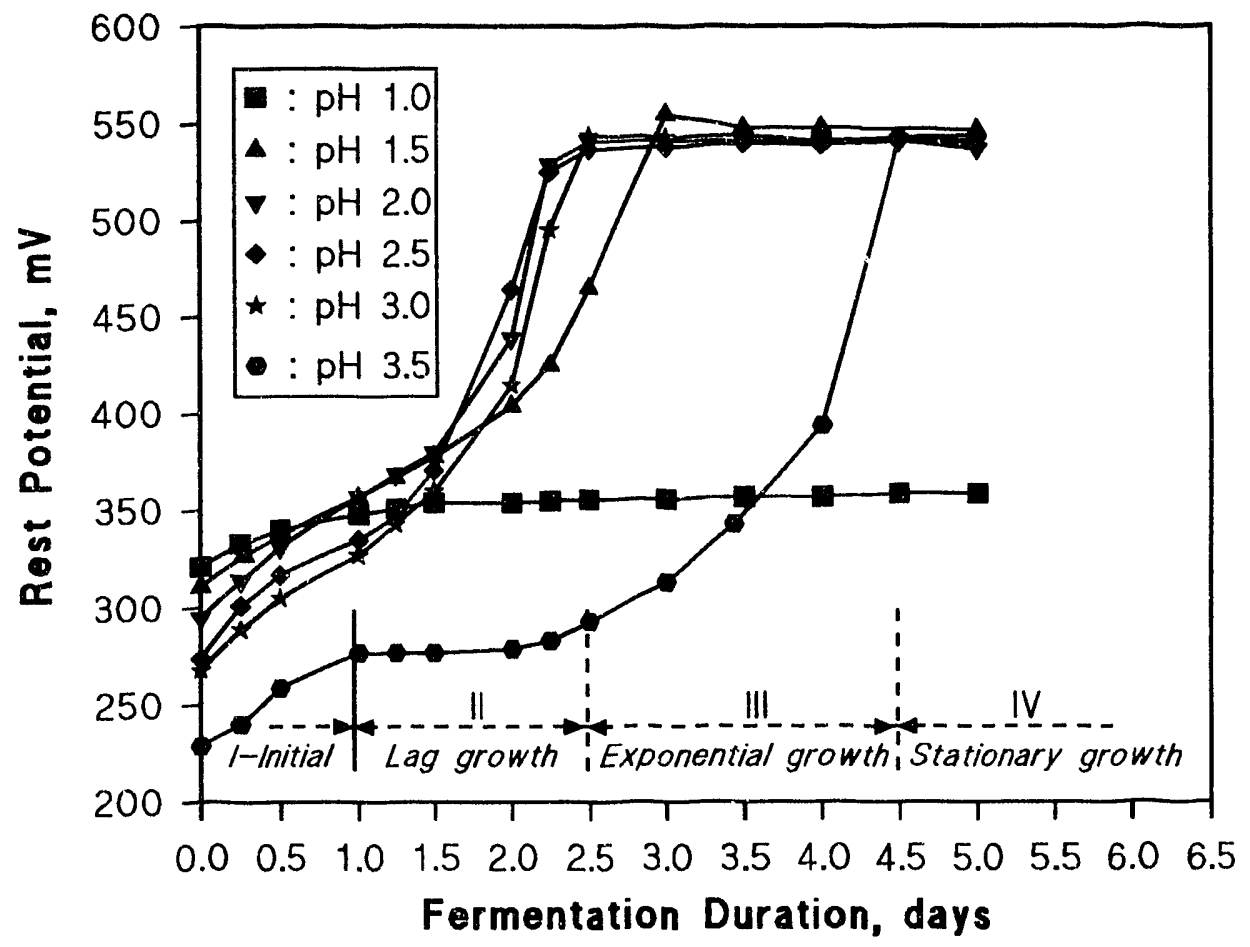

Figure 31 Redox potential variation during fermentation of T. ferrooxidans at different initial solution $\mathrm{pH}$. 


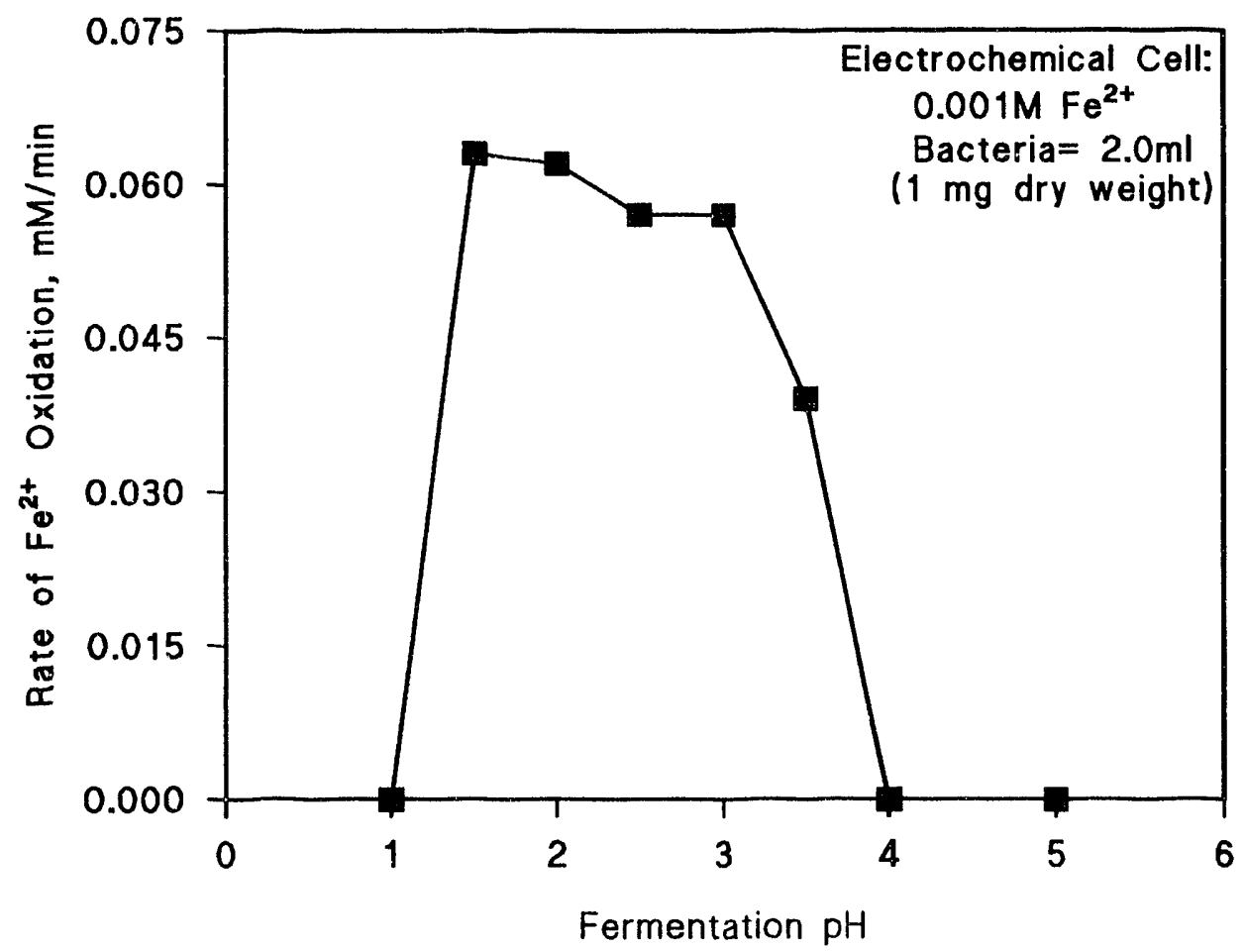

Fig. 32 Effect of fermentation pH on activity of harvested T. ferrooxidans. Activity measured in the electrochemical cell. 


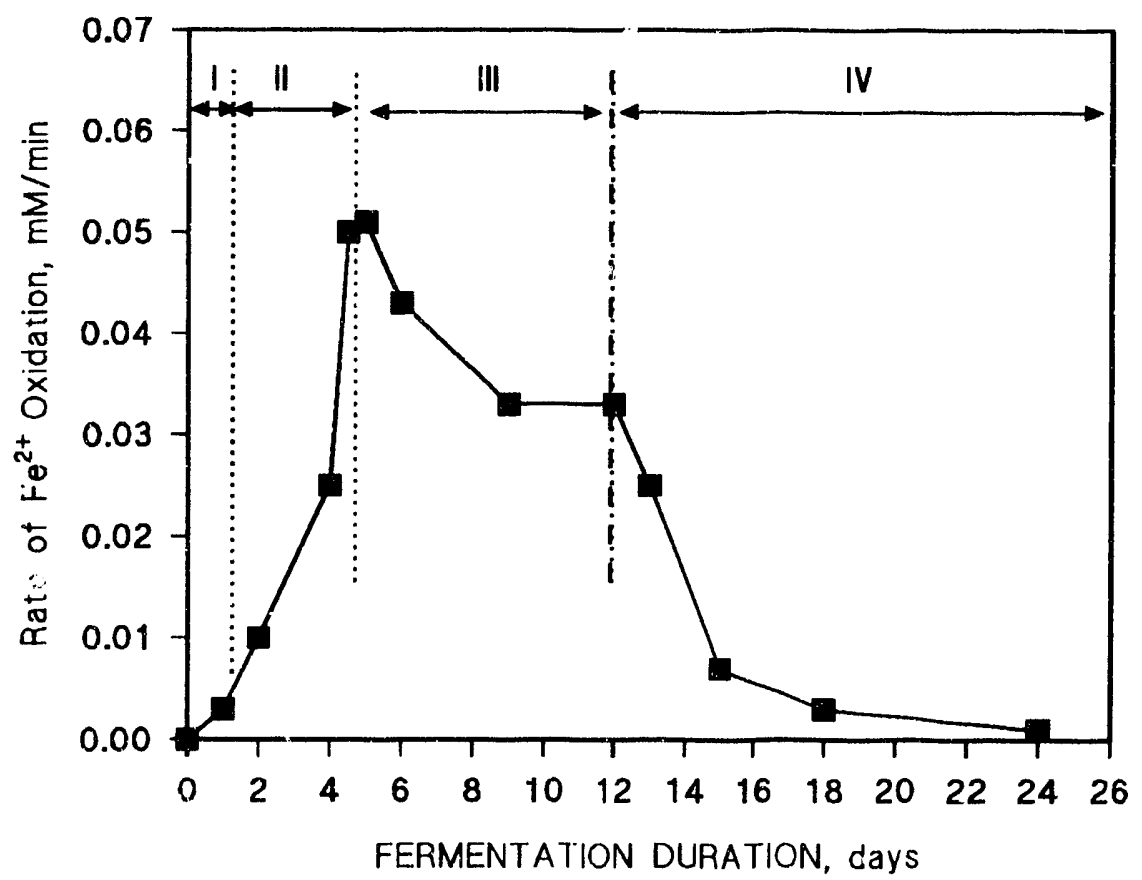

Fig. 33 Effect of time on growth of T. ferrooxidans. Activity of harvested cells measured in the electrochemical cell. 


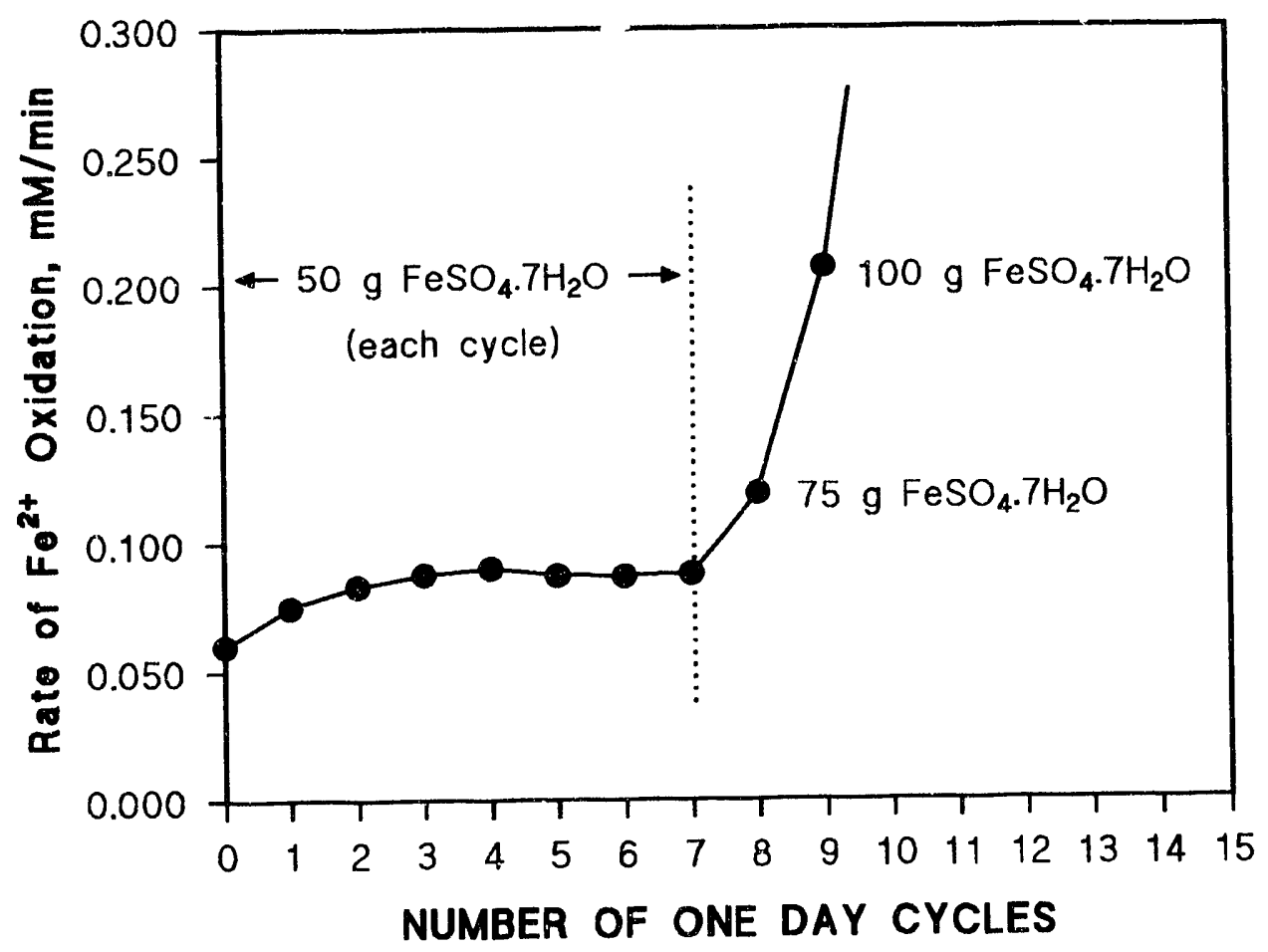

Fig. 34 Effect of recycling of harvested bacteria into fresh medium solution. Between recycling, the activity of harvested bacteria measured in the electrochemical cell. 


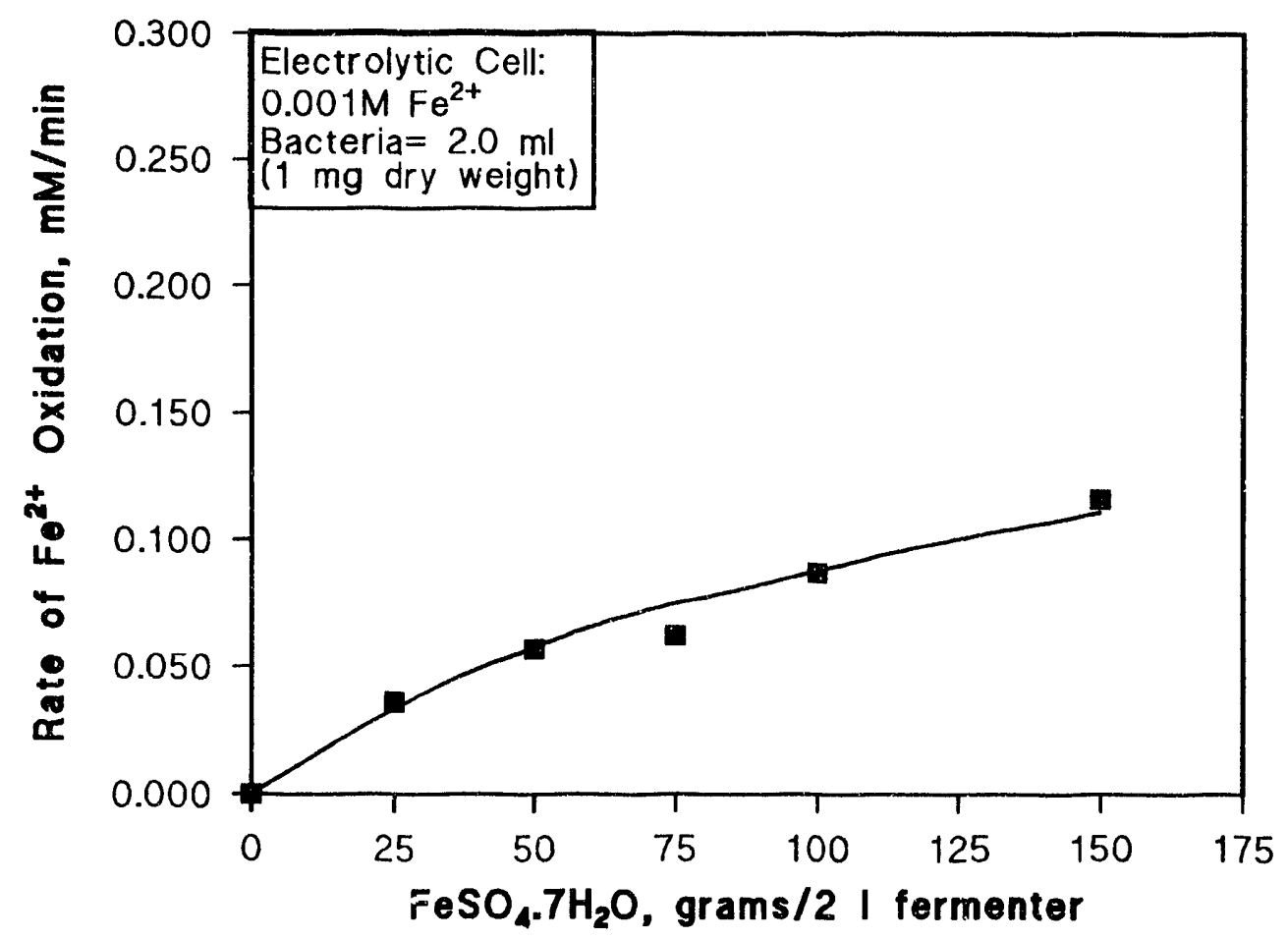

Fig. 35 Effect of ferrous sulfate addition on growth of $T$. ferrooxidans during fermentation. Activity of harvested bacteria measured in the electrolytic cell. 


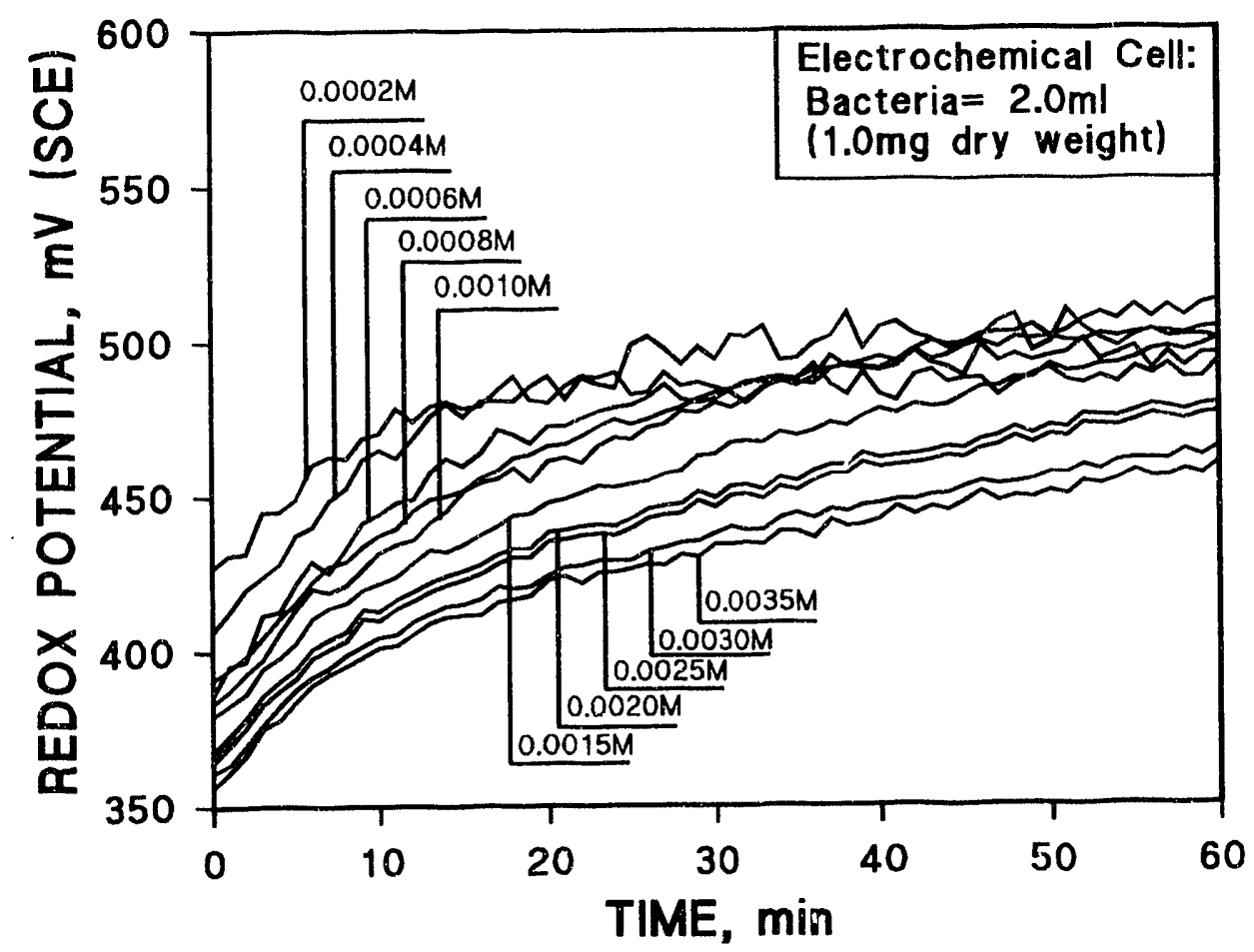

Fig. 36 Effect of $\mathrm{Fe}^{2+}$ concentration on the oxidation of ferrous iron with $T$. ferrooxidans. The curves are raw data of redox potentials acquired with time during oxidation of $\mathrm{Fe}^{2+}$ with harvested cells. 


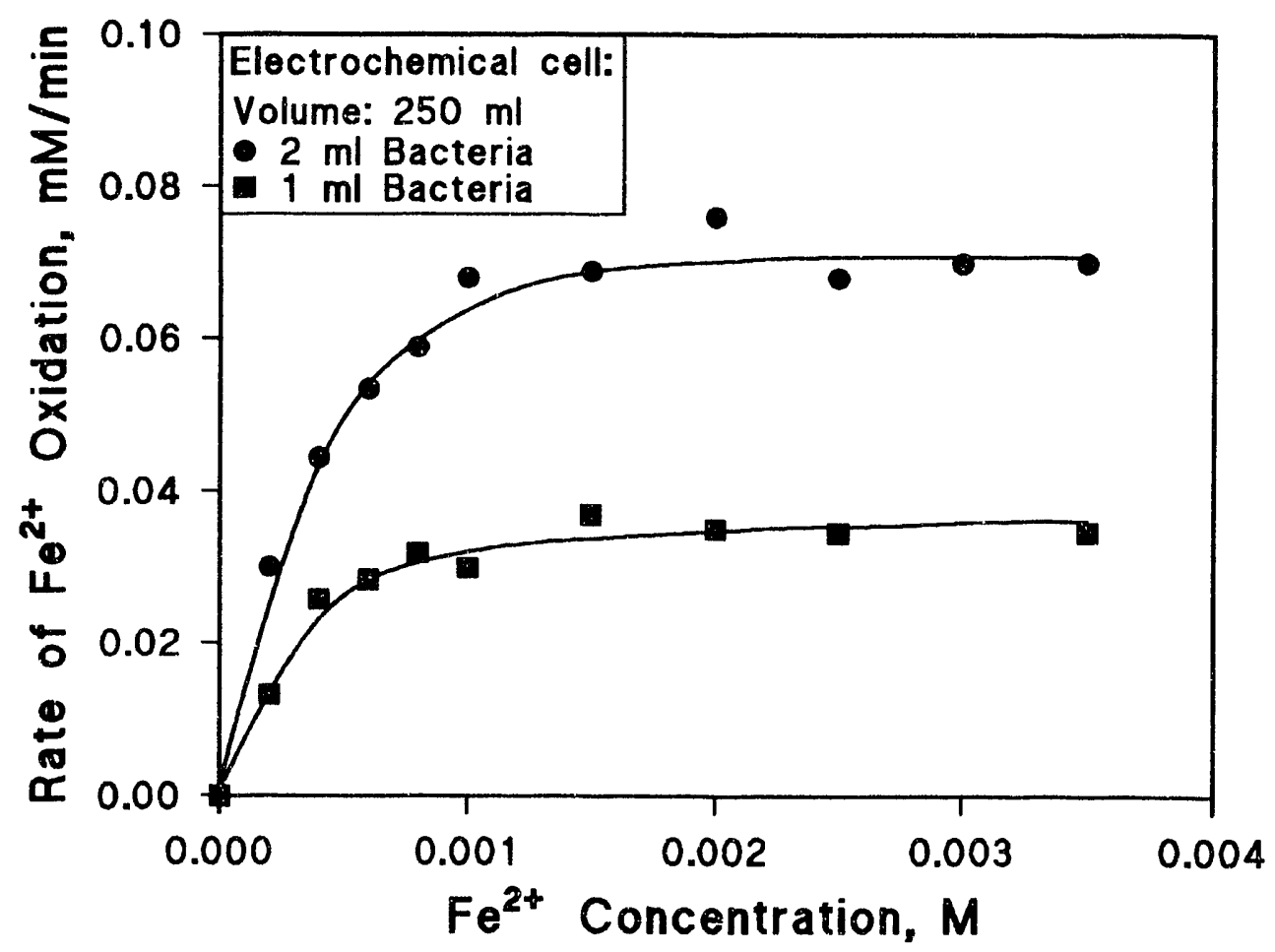

Fig. 37 Rate of $\mathrm{Fe}^{2+}$ oxidation with harvested $\mathrm{L}$. ferrooxidans cells as a function of substrate concentration. 


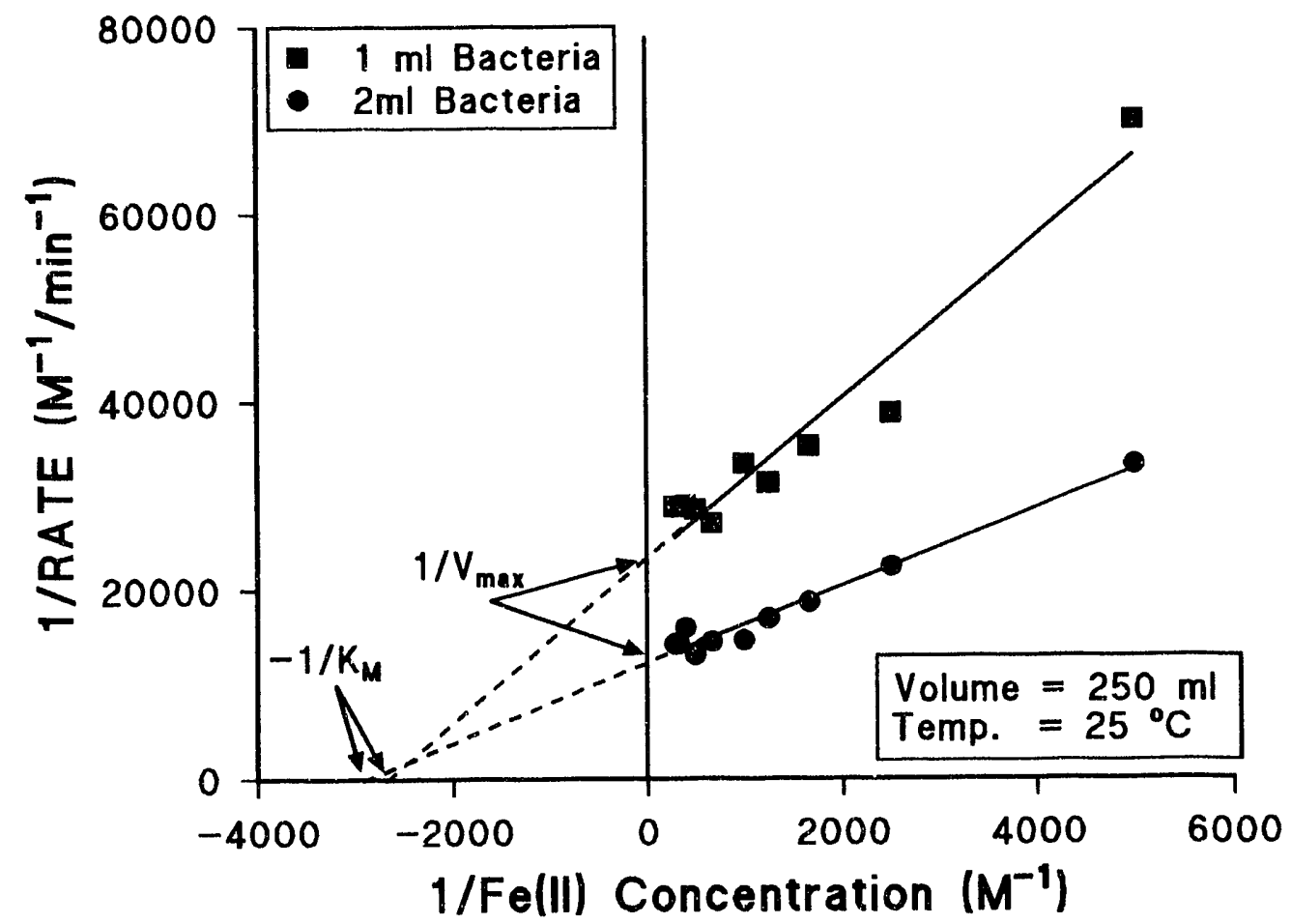

Fig. 38 Lineweaver-Burk plot: Effect of substrate concentration. Data from Figure 37. 


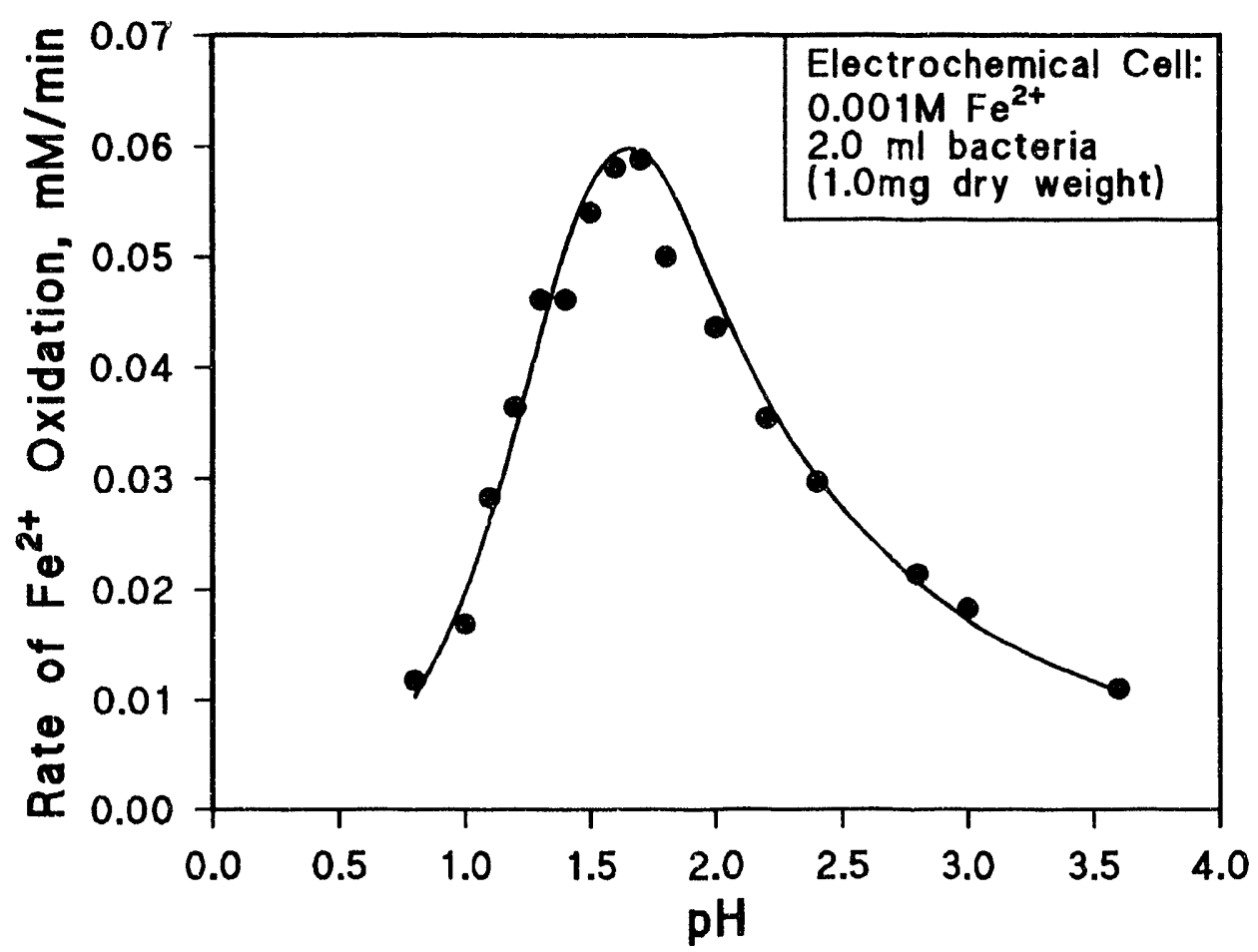

Fig. 39 Effect of $\mathrm{pH}$ on the rate of $\mathrm{Fe}^{2+}$ oxidation with harvested T. ferrooxidans cells. 


\section{CONCLUSIONS}

1. Cyclic voltammetric studies of pyrite in various solutions during bioleaching in the growth stage of $T$. ferrooxidans were performed in the range of $-0.2 \mathrm{~V}$ to $+0.8 \mathrm{~V}$. Performing several identical cyclic voltammetry studies produced reproducible results; the most drastic changes on the pyrite surface always occurred during the second day of bioleaching.

2. The oxidation-reduction reactions of iron on pyrite were susceptible to stirring during the initial two days of bioleaching. The reactions were irreversible, as evidenced by a high separation of peak currents. As the bioleaching progressed, the separation of peak currents decreased, but it never decreased enough to reach the reversible range.

3. After two days of bioleaching, the cyclic voltammograms no longer showed the effects of convective diffusion produced by stirring during air bubbling. It is proposed that the iron species trapped in the cracks of the product layer account for the absence of the effects of stirring from the CVs. The cracks were formed within the layer consisting of solid reaction products and bacterial cells.

4. The X-ray diffraction of the products obtained during bioleaching confirmed that jarosite was formed as the final 
reaction product.

5. The SEM analysis showed that the $T$. ferrooxidans cells suffer drastic changes during bioleaching. The cells initially serve as the nucleation sites for jarosite formation. With time, jarosite growth takes place at the expense of the cells, which slowly collapse. Finally, an individual cell collapses completely and becomes converted into several globules of a reaction product identified by X-ray diffraction and chemical characterization as jarosite.

6. Microbial oxidation of ferrous iron by T. ferrooxidans was studied using a variety of experimental conditions, e. g. solution $\mathrm{pH}$, temperature, concentrations of bacteria, ferrous and ferric iron, and some heavy metal ions, and period of conditioning the bacteria with heavy metal ions. All the experiments were conducted without addition of a nutrient in the system other than $\mathrm{Fe}(\mathrm{II})$. Moreover, the duration of experiments was only one hour which was too short a time for the bacteria to grow. Consequently, our results are not growth biased and may approximate to the true chemical activity of the bacteria. For this reason, care should be taken while comparing our results with other results which are growth biased in most cases. The important conclusions drawn on the basis of our work follow:

7. Ferrous iron oxidizing ability of the $\underline{T}$. ferrooxidans is 
found to be dependent on experimental conditions. Injtial pH of solution, temperature, $F e(I I)$ and the microbial cell concentration have significantly influenced the activity of the bacteria. The presence of some heavy metal ions in the system has also been observed to modulate the Fe(II) oxidizing activity of the I. ferrooxidans (Table 5). In our experiments, $\mathrm{Hg}$ (II), Ag(I), $\mathrm{Pb}(\mathrm{II})$ and $\mathrm{Cd}(\mathrm{II})$, up to a concentration level of $10 \mathrm{mg} / \mathrm{L}$ are observed to inhibit the microbial oxidation of F'e(II), while 10 $\mathrm{mg} / \mathrm{L}$ of $\mathrm{Zn}(\mathrm{II}), \mathrm{Cu}(\mathrm{II})$ and $\mathrm{Co}(\mathrm{II})$ have no noticeable effect. According to our results, $\mathrm{Hg}(\mathrm{II})$ and $\mathrm{Ag}(\mathrm{I})$ exert the most detrimental effect on the iron oxidizing activity of $\underline{T}$. ferrooxidans. Our results also reveal that $\mathrm{Mn}$ (II), As(III) and Sn(II) may not be conducive to microbial oxidation of $\mathrm{Fe}$ (II). Anions like $\mathrm{Cl}^{-}$and $\mathrm{NO}_{3}{ }^{-}$, upto the concentration level of $10 \mathrm{mg} / \mathrm{L}$, do not have an observable effect on the iron oxidizing activity of the bacteria.

8. Silver is likely to inhibit Fe(II) oxidizing ability of the bacteria by a mixed mechanism in which silver may compete with ferrous iron for the active site on the enzyme and also bind to the enzyme-substrate complex. On the other hand, inhibition of the microbial oxidation of $\mathrm{Fe}$ (II) by $\mathrm{Hg}$ (II) may take place via the uncompetitive mechanism, according to which mercury may bind to the enzyme-Fe(II) complex.

9. The mechanism of $\mathrm{T}$. Eerrooxidans mediated oxidation of 
$\mathrm{Fe}$ (II) is remarkably sensitive to temperature changes. In the vicinity of room temperature $\left(18-25^{\circ} \mathrm{C}\right)$, the reaction is controlled by the diffusion of $\mathrm{Fe}$ (II) whereas below $18^{\circ} \mathrm{C}$, the rate of Fe(II) oxidation is controlled by the kinetics of the reaction being studied. In experiments involving $10 \mathrm{mg} / \mathrm{L}$ silver, reaction kinetics is likely to be the rate limiting factor for the range of temperature, $5.5-25^{\circ} \mathrm{C}$. By contrast, Fe(II) oxidation by $\underline{\mathrm{T}}$. ferrooxidans is likely to be controlled by the diffusion of ferrous ions into periplasmic space both in the presence and in the absence of $10 \mathrm{mg} / \mathrm{L} \mathrm{Hg}(\mathrm{II})$.

10. The results obtained in the current study do not specify the site on the $\mathrm{T}$. Eerrooxidans cells at which silver and mercury may accumulate. However, based on the literature reports describing a great affinity of these metals for sulfur, it is likely that sulfur atoms of thiol (i.e. -SH) groups on the microbial proteins may be the potential sites for binding silver and mercury.

11. The variation in redox potential with time during studies with T. ferrooxidans offers important kinetic information.

12. During the growth stage, solution $\mathrm{pH}$ and environmental conditions were very important parameters. This bacterium did not grow well below $\mathrm{pH} 1.0$ and above $\mathrm{pH} 4.0$. 
13. With respect to the environmental conditions, bacterial growth was found to be significantly enhanced by transferring the cells into fresh fermentation solutions. This transfer must be followed by an increased amount of ferrous sulfate as the nutrient. Increasing the amount of ferrous sulfate added to the same fermentation solution did not increase the growth of bacteria significantly.

14. The redox potential method was also used to measure the activity of harvested $T$. ferrooxidans as a function of substrate concentration and $\mathrm{pH}$. It was found that this method can be used to obtain data to study the Michaelis-Menten enzyme kinetics.

15. Michaelis-Menten kinetic parameters were estimated by using the Lineweaver-Burk method. For $2 \mathrm{ml}$ of bacteria ( $1 \mathrm{mg}$ dry weight) these values were $K_{M}=0.336 M$ and $V_{\max }=0.0816 \mathrm{~mm} / \mathrm{min}$ dry weight.

16. The $\mathrm{pH}$ had a well-defined effect on the activity of $\mathrm{T}$. ferrooxidans, which increased with $\mathrm{pH}$ up to $\mathrm{pH}$ 1.6-1.7, and decreased with further increase in $\mathrm{pH}$. 


\section{REFERENCES}

1. Marchant, P. B., "Commercial piloting and the economic feasibility of plant scale continuous biological tank leaching at Equity Silver Mines Limited", Fundamental and Applied Biohydrometallurgy, Edited by R. W. Lawrence, R.M.R. Branion, and H. G. Ebner, pp. 53-76, Elsevier, New York, 1986.

2. Malouf, E. E., "The role of microorganisms in chemical mining", Mining Engineering Journal, November, pp. 43-46, 1971.

3. Monticello, D. J., and W. R. Finnery, "Microbial desulfurization of fossil fuels", Ann. Rev. Microbiol., 39:371$89,1985$.

4. Klainmann, R. L., D. A. Crerar, and R. R. Pacelli, "Biogeochemistry of acid mine drainage and a method to control acid formation", Mining Engineering, pp. 300-305, March 1981.

5. Iwasaki, I., and Natarajan, K. A., "Microbe-mineral interactions in the leaching of complex sulfides", Metallurgical Effects on Metallurgical Processes, Edited by Clum, J. A. and L. A. Haas, Metallurgical society of AIME, Warrendale, pp. 1-13, 1985.

6. Natarajan, K. A., and I. Iwasaki, "Role of galvanic 
interactions in the bioleaching of Duluth Gabbro copper-nickel sulfides", jeparation Science and Technology, 18 (12\&13), pp. $1095-1111,1983$.

7. Mehta, A. P., and L. E. Murr, "Kinetic study of sulfide leaching by galvanic interaction between chalcopyrite, pyrite, and sphalerite in the presence of $\mathrm{T}$. ferrooxidans $\left(30^{\circ} \mathrm{C}\right)$ and a thermophilic microorganism $\left(55^{\circ} \mathrm{C}\right) "$, Biotechnology and Bioengineering, 24:919-940, 1982 .

8. Mehta, A. P., and L. E. Murr, "Fundamental studies of the contribution of galvanic interaction to acid-bacterial leaching of mixed metal sulfides", Hydrometallurgy, 9:235-256, 1983.

9. Berry, V. K., L. E. Murr, and J. B. Hiskey, "Galvanic interaction between chalcopyrite and pyrite during bacterial leaching of low-grade waste", Hydrometallurgy, 3:309-326, (1978).

10. Chia, L. M, W. K. Choi, R. Guay and A. E. Torma, "Electrochemical aspects of pyrite oxidation by Thiobacillus ferrooxidans during leaching of a Canadian uranium ore", Biohydrometallurgy, Edts.: J. Salley, R.G.L. McCready, P.L. Wichlacz, Jackson Hole, Wyoming, Canmet (Canmet sp89-10), pp. 3547. August 13-18, 1989 .

11. Palencia, I., R. Y. Wan, and J. D. Miller, "The 
electrochemical behavior of a semicorductive natural pyrite in the presence of bacteria", Presented at Biohydrometallurgy Symposium, Jakson Hole, Wyoming, August 13-18, 1989.

12. Evans, D. H., K. M. O'Connell, R. A. Peterson, and M. J. Kelly, "Cyclic voltammetry", J. Chem. Educ., 60:290, 1983.

13. Van Benschoten, J.J., Lewis, J.Y., Heineman, W. R., Roston, D.A., and P. T. Kissinger, "Cyclic voltametry experiment", J. Chem. Educ., pp. 772-776, Vol 63, No. 9, 1983.

14. Kissinger, P. T., and W. R. Heineman, "Cyclic voltammetry", J. Chem. Educ., pp. 702-706, Vol. 60, No. 9, 1983.

15. Pesic B., D.J. Oliver, and P. Wichlacz, "An electrochemical method of measuring the oxidation rate of ferrous to ferric iron with oxygen in the presence of T. ferrooxidans". Biotechnology and Bioengineering, Vol. 33, No. 4, January 20, pp. 428-439, 1989.

16. Adams R. N., Electrochemistry at Solid Electrodes, Marcel Dekker, 1969.

17. Pesic, B., and Inbeum Kim, "Electrochemistry of $\underline{T}$. ferrooxidans interactions with pyrite", EPD Congress 190, Ed. D.R. Gaskell, The Minerals, Metals and Materials Society, 
Warrendale, pp. 133-160, 1990.

18. Ivarson, K.C., "Microbial formation of basic ferric sulfates", Can. J. Soil Sci., Vol. 53, pp. 315-323, 1973.

19. Ivarson, K.C., G.J. Ross, and N.M. Miles, "The microbiological formation of basic ferric sulfates: II. Crystallization in presence of potassium, ammonium and sodium salts", Soil Sci. Soc. Am. J., Vol. 43, pp. 908-912, 1979.

20. Lazaroff, N., W. Sigal, and A. Wasserman, "Iron oxidation and precipitation of ferric hydroxysulfates by resting Thiobacillus Eerrooxidans cells", Applied and Environmental Microbiology, Vol. 43, pp. 924-938, 1982.

21. Lazaroff, N., "The exclusion of $\mathrm{D}_{2} \mathrm{O}$ from the hydration shere of $\mathrm{FeSO}_{4} \cdot 7 \mathrm{H}_{2} \mathrm{O}$ oxidized by Thiobacillus ferrooxidans", Science, Vol. 222, pp. 1331-1334, 1983.

22. Toro, L., Paponetti, B., and Cantalini, C., "Precipitate formation in the oxidation of ferrous ions in the presence of Thiobacillus ferrooxidans", Hydrometallurgy, Vol. 20, pp. 1-9, 1988 .

23. P. R. Norris and D. P. Kelly ed., Biohydrometallurgy: Proc. Int. Symp. (Warwick, 1987, Science and Technology Letters), p. 
$177-325,1988$.

24. B. J. Scheiner, F. M. Doyle and S. K. Kawatra ed., Biotech. Miner. Met. Process., (Littleton, CO: Society of Mining Engineers Inc), p. $9-31,1989$.

25. R. W. Bartlett, "Aeration Pretreatment of Low Grade Refractory Gold Ores", Miner. Met. Process., p. 22, Feb. 1990.

26. R. W. Bartlett, Solution mining, Gordon and Breach Science Publishers, Philadelphia, p. 113, 1992.

27. F. Kargi and J. G. Weissman, Biotech. Bioeng., vol 26 , p. 604,1984

28. A. E. Torma and T. M. Olsen, "Kinetics of biodesulfurization of high sulfur coal", Appl. Biochem. Biotech., vol 18, p. 341, 1988 .

29. P. Dugan, "Microbiological desulfurization of coal and its increased monetary value", Biotech. Bioeng. Sump., vol 16, p. $185,1986$.

30. F. Kargi, "Microbiological coal desulfurization", Enzym. Microb. Technol., vol 4(1), 13, 1992. 
31. K. Imai, T. Sugio, T. Tsuchida and T. Tano, "Effect of Heavy Metal Ions on the Growth and Iron-oxidizing Activity of Thiobacillus ferrooxidans", Agri. Biol. Chem., vol. 39(7), p. 1349,1975 .

32. P. R. Norris and D. P. Kelly ed., Biohydrometallurgy: Proc. Int. Symp., (Warwick, 1987, Science and Technology Letters), $p$. 103,1988 .

33. ibid, p. 89 .

34. T. K. Datta, N. Ghosh, R. Sen and A. K. Dasgupta, "Pretreatment of Chalcopyrite Ore with Alkali: A Simple Technique to Improve the Leaching Mediated by T. ferrooxidans", Miner. Eng., vol. 3(6), p. 641 and references cited therein, 1990.

35. T. G. Spiro ed., Metal Ion Activation of Dioxygen, J. Wiley and Sons, p. 209, 1980 .

36. O. H. Tuovinen and D. P. Kelly, "studies on the Growth of Thiobacillus ferrooxidans II", Archiev. Microbiol., vol $95, p$. 153,1974 .

37. B. J. Scheiner, F. M. Doyle and S. K. Kawatra ed., Biotech. Miner. Met. Process., (Littleton $\mathrm{CO}$ : Society of Mining Engineers Inc.), p. 95, 1989 . 
38. P. Roy and A. K. Mishra, "Iron Oxidation not Coupled to Growth in Thiobacillus ferrooxidans in Presence of Toxic Metals", J. Appl. Bact., vol. 51, p. 387, 1981.

39. O. H. Tuovinen, J. Puhakka, P. Hiltunen and K. M. Dolan, "Silver Toxicity to Ferrous Iron and Pyrite oxidation and its Alleviation by Yeast Extracts in Cultures of Thiobacillus ferrooxidans, Biotech. Lett., vol. 7(6), p. 389, 1985.

40. B. Volesky ed., Biosorptions of Heavy Metals, CRC Press, Boston, p.104, 1990 .

41. P. R. Norris and D. P. Kelly ed., Biohydrometallurgy: Proc. Int. Symp., (Warwick, 1987, Science and Technology Letters, p. $287,1988$.

42. A. Bruynesteyn, R. H. Hackl, R. W. Lawrence and A. I. Vizsolyl, United States Patent 4,571,387, p. 59, Feb. 1986.

43. L. Ahonen and O. H. Tuovinen, "Catalytic Effects of Silver in the Microbiological Leaching of Finely Ground Chalcopyritecontaining Ore Materials in Shake Flasks", Hydrometallurgy., vol. 24, p. 219, 1990 .

44. G. Rossi, Biohydrometallurgy, McGraw Hill, Hamburg, p. 188, 1990. 
45. J. E. Hobbie, R. J. Daley and S. Jasper, "Use of nucleopore filters for counting bacteria by fluorescence microscopy", Appl. Environ. Microbiol., vol 33, p. 1225, 1977.

46. C. A. Jones and D. P. Kelly, "Growth of $\underline{T}$ ferrooxidans on ferrous iron in chemostat culture: influence of product and substrate inhibition", J. Chem. Tech. Biotech., vol. 33B, p. 241, 1983

47. P. R. Norris and D. P. Kelly ed., Biohydrometallyrgy:

Proc. Int. Symp. (Warwick, 1987, Science and Technology Letters), p. 43-59, 1988 .

48. D. P. Kelly and C. A. Jones, "Metallurgical applications of bacterial leaching and related microbiological phenomena", L. E. Murr, A. E. Torma and J. A. Brierley, eds., Academic press, N. Y, 1978

49. J. F. Braddock, H. V. Luong and E. J. Brawn, Appl. Environ. Microbiol., Vol 48, p. $48,1984$.

50. D. P. Kelly, M. Eccleston and C. A. Jones, Geburtsh. Frauenheilkd. vol. 4, p. 2, 1977.

51. G. Rossi, Biohydrometallurgy, McGraw Hill Co., Hamburg., p. 194 and references cited therein, 1990. 
52. G. Rossi, Biohydrometallurgy, MC Graw Hill Co. New York, p. 143 and references cited therein, 1990 .

53. B. Volesky ed., Biosorption of heavy metals, CRC Press, Boston, p. 106 and references cited therein, 1990.

54. D. Voet and J. G. Voet, Biochemistry, J. Wiley and Sons Co., N. Y., p. 343, 1990 .

55. F. D. Pooley, "Bacteria accumulate silver during leaching of sulfide ore minerals", Nature, vol 296, p. 642, April 1982.

56. J. T. Trevors, "Silver resistance and accumulation in bacterial, Enzyme Microb. Technol., vol 9, p. 331, 1987.

57. R. C. Tilton and B. Rosenburg, Appl. Environ. Microbiol., vol 35, p. 1116, 1978.

58. B. Volesky (ed), Biosorption of heavy metals, CRC press, Boston, p. 577, 1990 .

59. D. J. Oliver, University of Idaho, Moscow, Idaho 83843 , private communication.

60. B. Pesic and I. Kim, Mineral Bioprocessing, Engineering Foundation Conference, Edts. R. W. Smith and M. Misra, The 
Minerals, Metals \& Materials Society, pp. 413-432, 1991.

61. P.R. Norris, D.W. Barr and D. Hinson, Biohydrometallurgy, Proc. Int. Symp., Warwick 1987, pp. 43-59, Edts. P.R. Norris and D. P. Kelly, Antony Rowe Ltd, Great Britain, 1988.

62. G. Rossi, Biohydrometallurgy, MCGraw-Hill, 1990.

63. A. E. Torma, Advances in Biochemical Engineering, Vol. 6, pp. 1-37, Edts. T.K. Ghose, A. Fiechter, N. Blakebrough, SpringVerlag, 1977 .

64. I. Kim, "Electrochemistry of interaction of $\mathrm{T}$. ferrooxidans with pyrite" (Ph.D. thesis, University of Idaho, 1992). 

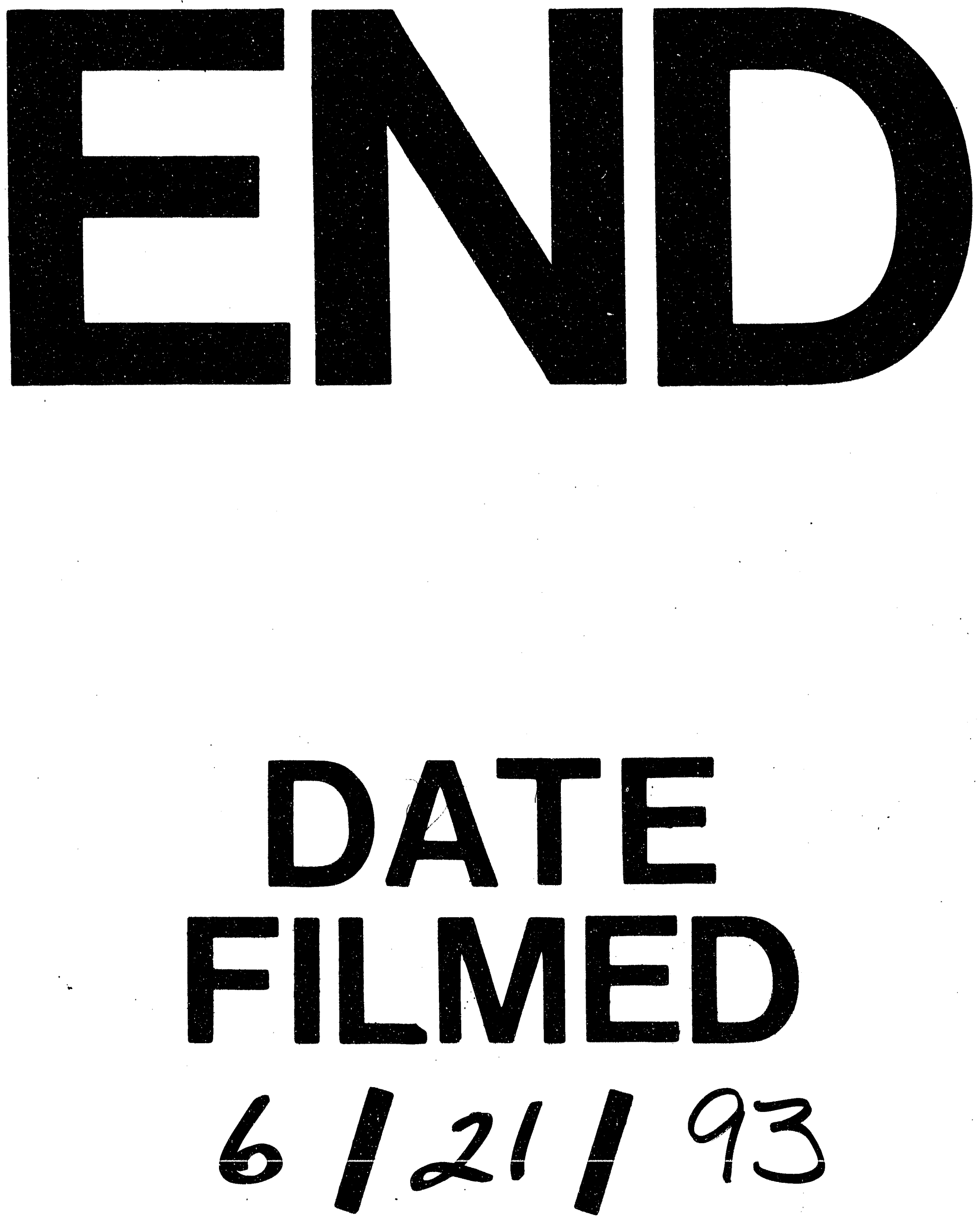
